\title{
Proteínas recombinantes útiles para el diagnóstico, prevención y estudios patogénicos de la leptospirosis. Estudio de mecanismos patogénicos involucrados
}

\author{
Bca. Gabriela Prêtre
}

Director: Dr. Ricardo M. Gómez

Co-directora: Dra. Soledad Negrotto

Instituto de Biotecnología y Biología Molecular (CONICET-UNLP) Instituto de Medicina Experimental (CONICET-ANM)

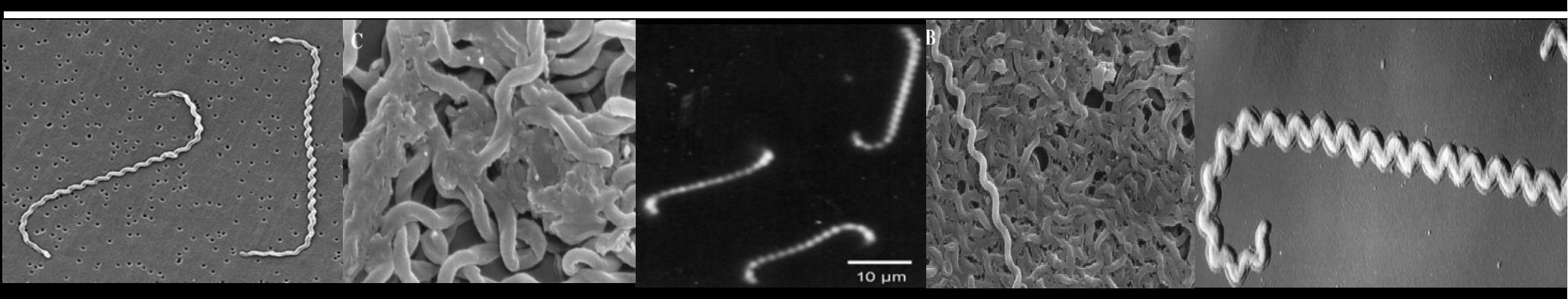


A mamá y a papá por darme la vida,

A Martina y a Emma por iluminarla 


\section{Agradecimientos}

Mi reconocimiento a la Facultad de Cs. Exactas de la UNLP por brindarme su formación gratuitamente, al IBBM por haberme dado el ámbito propicio para realizar mi trabajo de tesis doctoral y a la Agencia Nacional de Promoción Científica y Tecnológica, por becar mí trabajo

Al Dr. Víctor Romanowski por permitirme trabajar en su laboratorio

A Ana Lucia do Nascimento por cooperar en este trabajo

A Mirta Schattner por su valiosa ayuda leyéndome la tesis, por sus aportes y por permitirme trabajar en su laboratorio

A Soledad Negrotto por su ayuda y codirección

A Martín Rumbo y a Guillermo Docena por su generosidad y buena predisposición

A Bibiana Deodato por su tiempo. A Bibiana Brihuega por facilitarme las cepas con las cuales trabajé y a Karina Caimi por la buena onda y el apoyo

A Laura Briand y a Virginia Vetere, por permitirme formar parte de sus proyectos de extensión. A Fernando Pérez por su generosidad y por su apoyo

A Maria Elena Vela por su contención y a Tati Prieto por su ayuda y a mis compañeros de cátedra Agus, Emi, Meli, Carla, Vir, Anto, Romi y Juanjo por tantas tardes y risas compartidas

A Katy, Paula, Gisela, Abel y Silvana por haberme dado una mano en todo momento en especial a Bernabé por haber cuidado de Syd

A los VA mas nuevos, Maia, Mati, Lucre, Leo, Jesi, Flor, Malen por bancarme en la última etapa tan caótica. A los VA que ya no están, Gordo, Ale, Colo, Fer por bancarme en mis inicios depresivos. A los VA de siempre, Santi, Noe, Leti y Caro por bancarme caótica, depresiva, histérica, distraída malhumorada...en fin... 
GRACIAS VA!!! LOS QUIERO MUUUCHOO!!! (y agarren la pala!)

A mis cuñadas Naty, Caro y María Julia por su afecto

A mis Amigas del Alma Luli, Sil y Emi por tanta vida recorrida. A mis "Gurúes Espirituales" la Gran Lulú y a la Dra. Matkovic por escucharme, contenerme y aconsejarme. A Eitel por estar en el día a día

Al "Pariente" Casanova que me viene bancando mudanza a mudanza, llevándome y trayéndome, cocinándome chipá y estando siempre presente como un verdadero Hermano. Gracias Fer!!!

A mis Hermanas de la Vida, Bingui, Euge y Meli por quererme tanto y por tantos años de amistad incondicional, las amo con todo mi corazón!!!

A mis "Guardaespaldas", los mejores hermanos del mundo, Juan y Vicky por las peleas y las alegrías, por hacerme sentir querida y protegida, por cuidar de mi

A Javi porque estuvo, está y estará haciéndome renegar, haciéndome reír, haciéndome feliz

A mis dos soles Emma y Martu por enseñarme a ver la sencillez de la vida

A Papá y Mamá por cuidarme tantas veces; por darme sus fuerzas cuando yo no las tenía, por los momentos felices que compartimos, por contenerme, por aguantar mis locuras, por las segundas oportunidades, por cuestionar mis decisiones aun contando con su apoyo, por confiar en mí siempre, por tanto amor A " $R$ " por estar presente en cada momento de mi tesis, por soportar mis nervios, por su ayuda, por su crítica, por su generosidad, por su confianza. Por tantos "I don't care gabi" que detonaban en mi una mezcla de furia y gracia que voy a extrañar. Por haberme mostrado que, además de ser un buen director, es una excelente persona, razón por la cual lo estimo y lo respeto 


\section{Índice}

$\begin{array}{lr}\text { Abreviaturas } & 10\end{array}$

Capítulo 1: Introducción General 12

$\begin{array}{ll}\text { 1.1.- Aspectos Históricos } & 13\end{array}$

$\begin{array}{ll}\text { 1.2.- Leptospiras, generalidades } & 13\end{array}$

$\begin{array}{ll}\text { 1.3.- Taxonomía y clasificación } & 16\end{array}$

$\begin{array}{ll}\text { 1.4.- Epidemiología } & 18\end{array}$

$\begin{array}{lr}\text { 1.5.- Reservorio } & 19\end{array}$

$\begin{array}{ll}\text { 1.6.- Mecanismo de transmisión } & 19\end{array}$

$\begin{array}{lr}\text { 1.7.- Historia Natural } & 21\end{array}$

$\begin{array}{lr}\text { 1.8.- Síndrome de Weil } & 24\end{array}$

1.9.- Datos de laboratorio $\quad 25$

$\begin{array}{lr}\text { 1.10.- Respuesta inmune } & 25\end{array}$

$\begin{array}{ll}\text { 1.11.- Patogénesis } & 26\end{array}$

1.12.- Modelos animales $\quad 28$

1.13.- Diagnóstico 29

$\begin{array}{ll}\text { 1.14.- Pruebas serológicas } & 30\end{array}$

$\begin{array}{ll}\text { 1.15.- Diagnóstico diferencial } & 30\end{array}$

$\begin{array}{ll}\text { 1.16.- Tratamiento } & 31\end{array}$

$\begin{array}{ll}\text { 1.17.- Pronóstico } & 32\end{array}$

1.18.- Profilaxis 32

1.19.- Medidas de control 33

1.20.- Vigilancia epidemiológica 33 
1.22.- Impacto socio-económico 36

$\begin{array}{ll}\text { Objetivos } & 37\end{array}$

Capítulo 2: Herramientas moleculares útiles para el diagnóstico, prevención y estudios patogénicos de la leptospirosis

2.1.- Introducción

2.2.- Justificación de los candidatos seleccionados

2.3.2 Análisis bioinformático de la secuencia de LIC12690, LIC11207 y LIC12922

2.3.3 Comparación de las secuencias de LIC12690, LIC11207 y LIC12922 con otras adhesinas leptospirales reportadas

2.3.4 Distribución de los genes lic12690, lic11207 y lic12922 entre las distintas especies de leptospiras

2.3.5 Análisis transcripcional de los genes lic12690, lic11207 y lic12922 entre las distintas especies de leptospiras

2.3.6 Clonado, expresión y purificación de las proteínas recombinantes

2.3.8 Reactividad de las proteínas recombinantes con los sueros de pacientes infectados

\subsubsection{Activación endotelial}

a) Cultivo de HUVEC

b) Medida del contenido de LPS

c) Expresión endotelial de E-selectiva e ICAM-1

d) Comparación de la expresión endotelial de E-selectiva e ICAM1 promovida por L. Interrogans y L. biflexa 
e) Liberación de vWF 72

2.3.10 Inhibición de la apoptosis $\quad 74$

$\begin{array}{ll}\text { 2.4.- Discusión } & 78\end{array}$

Capítulo 3: Estudio de mecanismos patogénicos involucrados: El rol de la óxido nítrico sintasa inducible (iNOS) en la leptospirosis 83

$\begin{array}{lr}\text { 3.1.- Introducción } & 84\end{array}$

$\begin{array}{lc}\text { 3.2.- Resultados } & 88\end{array}$

$\begin{array}{ll}\text { 3.2.1 Virulencia } & 88\end{array}$

3.2.2 Elección del modelo animal 89

3.2.3 Expresión renal de iNOS 92

$\begin{array}{ll}\text { 3.2.4 Curso clínico } & 95\end{array}$

$\begin{array}{ll}\text { 3.2.5 Carga bacteriana } & 96\end{array}$

$\begin{array}{ll}\text { 3.2.6 Hallazgos histológicos } & 97\end{array}$

$\begin{array}{ll}\text { 3.2.7 Respuesta humoral } & 98\end{array}$

$\begin{array}{ll}\text { 3.3.- Discusión } & 100\end{array}$

Capítulo 4: Conclusiones generales y perspectivas 104

$\begin{array}{lr}\text { 4.1.- Conclusiones generales } & 105\end{array}$

$\begin{array}{ll}\text { 4.2.- Perspectivas } & 107\end{array}$

Capítulo 5: Materiales y métodos 108

$\begin{array}{ll}\text { 5.1.- Productos químicos y enzimas } & 109\end{array}$

$\begin{array}{lr}\text { 5.2.- Medios } & 109\end{array}$

$\begin{array}{ll}\text { 5.3.- Cepas bacterianas utilizadas } & 113\end{array}$ 
5.8.- Selección in sílico de LIC12690, LIC11207, LIC12922 y comparación con otras adhesinas leptospirales

5.12.- Curvas de calibración para la cuantificación de leptospiras por qPCR

5.13.- Curva de calibración de B-actina transcripto, b-actina genómico e iNOS

5.15.5 Digestión por enzimas de restricción

\subsubsection{Expresión}

5.19.- Análisis de reactividad entre suero de pacientes y las proteínas recombinantes 
5.22.- Caracterización de la actividad biológica de las proteínas recombinantes sobre las células endoteliales

5.23.- Capacidad de las proteínas recombinantes de inhibir la apoptosis

5.23.1 Aislamiento de células polimorfonucleares (PMN) humanas

5.23.2 Tinción de naranja de acridina y bromuro de etidio para la determinación de la viabilidad celular 


\section{Abreviaturas}

4-AP 4-aminopiridina

aas aminoácidos

ADN ácido desoxirribonucleico

ADNc ácido desoxirribonucleico complementario

ARNm ácido ribonucleico mensajero

cNOS óxido nítrico sintasas constitutivas

CPK creatina fosfoquinasa

Ct ciclo umbral

DAB diaminobencidina

DO densidad óptica

dpi día posinfección

ECG electrocardiograma

ELISA ensayo por inmunoabsorción ligado a enzimas

EMJH Ellinghausen-McCullough-Johnson-Harris medio

eNOS óxido nítrico sintasa endotelial

FAD flavina adenina dinucleótido

FMN flavina mononucleótido

IL1 $\beta$ interleuquina 1 beta

im intramuscular

iNOS óxido nítrico sintasa inducible

iv intravenosa

LCR líquido cefalorraquídeo 
LIC Leptospira interrogans serovar Copenhageni

LPS lipopolisacárido

MAT test de aglutinación microscópica

MCP-1 proteína quimoatractante de monocitos 1

NADP $^{+}$nicotinamida adenina dinucleótido fosfato oxidada

NADPH nicotinamida adenina dinucleótido fosfato reducida

NF-к $\boldsymbol{\beta}$ factor nuclear kappa beta

nNOS óxido nítrico sintasa neuronal

NO óxido nítrico

NOS óxido nítrico sintasas

OMPs proteínas de membrana externa

PBS de buffer fosfato salino

PCR reacción en cadena de la polimerasa

pi posinfección

qPCR PCR en tiempo real

SNC sistema nervioso central

TLRs receptores tipo toll

TNF $\alpha$ factor de necrosis tumoral alfa

vo vía oral

vWF Factor de von Willebrand 


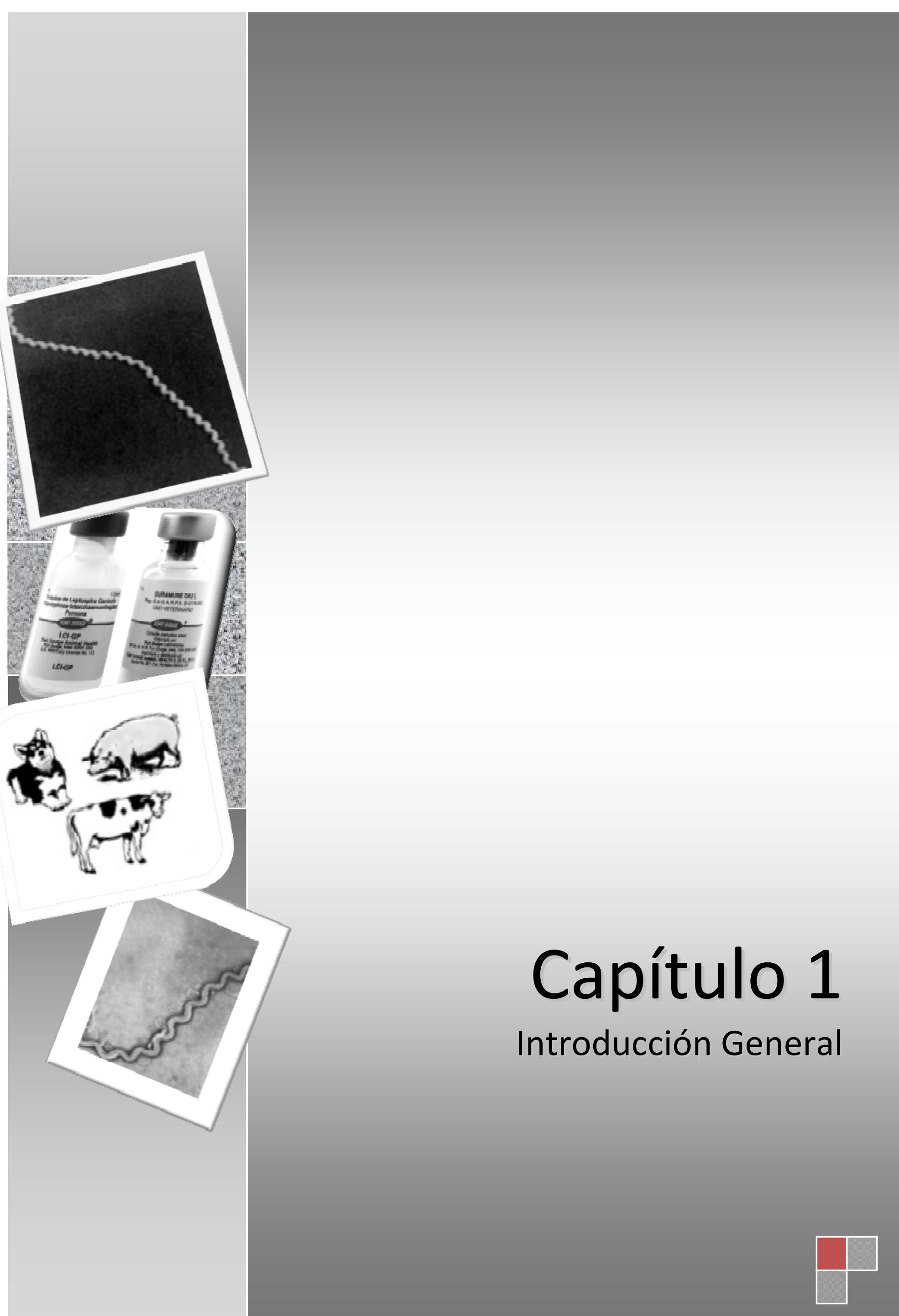




\subsection{Aspectos Históricos}

La leptospirosis es una zoonosis de distribución mundial causada por la infección de especies patogénicas de Leptospira. El espectro de síntomas de la enfermedad en humanos es extremadamente amplio y abarca desde una infección subclínica a un síndrome severo de infección multiorgánica con alta mortalidad. Si bien existió una descripción previa en trabajadores cloacales (Landouzy, 1883), el síndrome de leptospirosis ictérica con fallo renal es reconocido por primera vez hace más de 100 años por la descripción de Adolf Weil en Heidelberg (Weil, 1886), razón por la cual todavía se lo conoce como Síndrome de Weil.

La leptospirosis fue introducida en Europa occidental recién en el siglo XVIII a través de la expansión de Rattus norvegicus desde Eurasia (Alston, 1958). La etiología de la leptospirosis fue demostrada en Japón en el año 1915 (Everard, 1996). Poco tiempo después se describió el papel de la rata en la infección humana (Ido, 1917).

\subsection{Leptospiras, generalidades}

Las leptospiras son bacterias que pertenecen al orden de las Spirochaetales, familia Leptospiraceae, género Leptospira. Son células helicoidales, flexibles, que miden $0.1 \mu \mathrm{m}$ de diámetro y de 6 a $20 \mu \mathrm{m}$ de longitud y poseen una morfología estrechamente enrollada (Figura 1.1). Cuentan con la presencia de flagelos especiales denominados filamentos axiales, situados entre la envoltura celular externa y el cilindro protoplasmático (en el espacio periplasmático) que producen un movimiento giratorio que permite a la bacteria entera desplazarse hacia adelante. Los flagelos se insertan por un extremo cerca de cada polo celular, quedando el otro extremo libre el cual está dirigido hacia el 
centro de la bacteria. Los flagelos son de estructura y composición similar al resto de las bacterias, diferenciándose en que son completamente intracelulares.

Las proteínas FlaA y FlaB constituyen la vaina flagelar y el core, respectivamente. Se ha visto por microscopía electrónica que un mutante de FlaB resultó ser deficiente en endoflagelo y por lo tanto carente de movilidad (Picardeau et al., 2001).

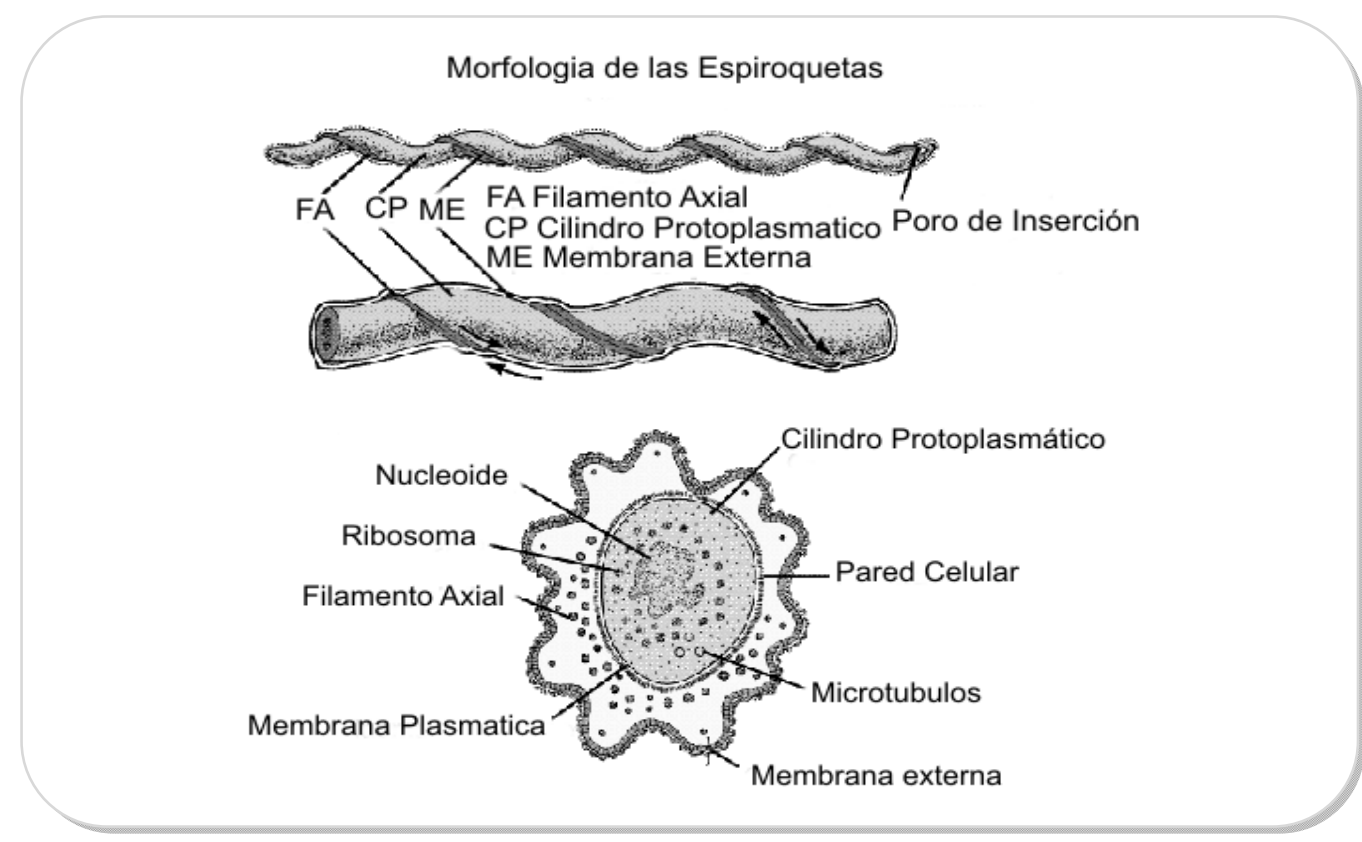

Figura 1.1 Esquema de la morfología de espiroquetas (Adaptado de Microbiology, 6ta ed., McGraw-Hill).

Algunas leptospiras pueden presentar sus extremidades incurvadas, como es el caso de $L$. interrogans. Todas las leptospiras poseen una envoltura celular similar a la de las bacterias Gram negativas, que consiste en una membrana citoplasmática y otra externa. Sin embargo, la capa de peptidoglicano está asociada con la membrana citoplasmática en lugar de con la membrana externa, algo que es único de las espiroquetas. Son aerobios estrictos, su temperatura óptima de crecimiento es entre 28 y 30 으, viven por largo tiempo en agua fresca, estiércol, barro y ambientes marinos aunque son fácilmente destruidas por calor, 
desinfectantes, desecación y acidez. Viven en asociación con huéspedes humanos y animales. La agregación celular de leptospiras prolonga el período de supervivencia en ambientes acuosos (Trueba et al., 2004), así también como la formación de biofilms, la cual es consistente con la vida en agua de las especies saprófitas y podría contribuir a la supervivencia de las especies patogénicas tanto en el ambiente como en el huésped colonizado (Ristow et al., 2008). La amplia distribución de las especies de Leptospiras, reflejan la habilidad de sobrevivir en diferentes condiciones ambientales, lo que muestra una gran capacidad de adaptación que implica una amplia plasticidad genómica (Zuerner et al., 1993).

A pesar de poseer la estructura de pared celular característica de las bacterias Gram negativas, se tiñen débilmente por el método de Gram. Para su observación se utilizan técnicas de impregnación argéntica. Debido a que son muy finas poseen escaso contraste al microscopio óptico en fresco, pero con un microscopio de campo oscuro pueden observarse claramente (Figura 1.2) (Plank and Dean, 2000).

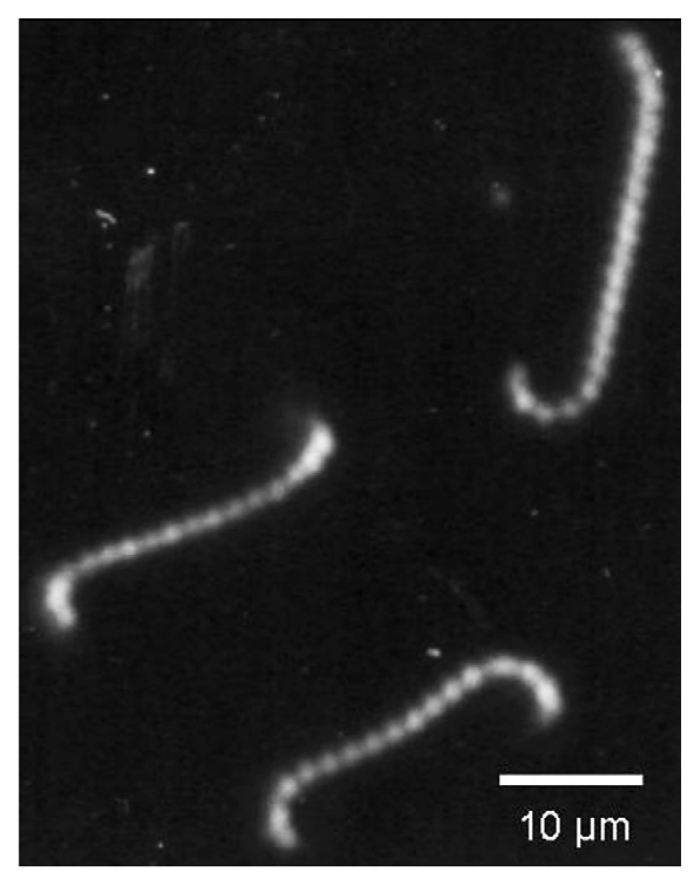

Figura 1.2 Microscopía de campo oscuro. 


\subsection{Taxonomía y clasificación}

El género Leptospira pertenece al phylum de espiroquetas y comprende a las especies saprófitas y a las patogénicas que infectan tanto a humanos como a animales. El análisis filogenético (Victoria et al., 2008) y el clustering genómico (Figura 1.3) (Ciccarelli et al., 2006) indican que las especies de leptospiras forman un único grupo evolutivo. El subgrupo de las saprófitas, el cual incluye Leptospira biflexa, forma la rama más profunda dentro del género, mientras que otro subgrupo incluye a las especies patogénicas tales como Leptospira interrogans y Leptospira borgpetersenii. Otra rama evolutiva comprende al subgrupo llamado "intermedio", el cual contiene especies cuya patogenicidad aún no ha sido esclarecida (Bharti et al., 2003; Levett, 2001).

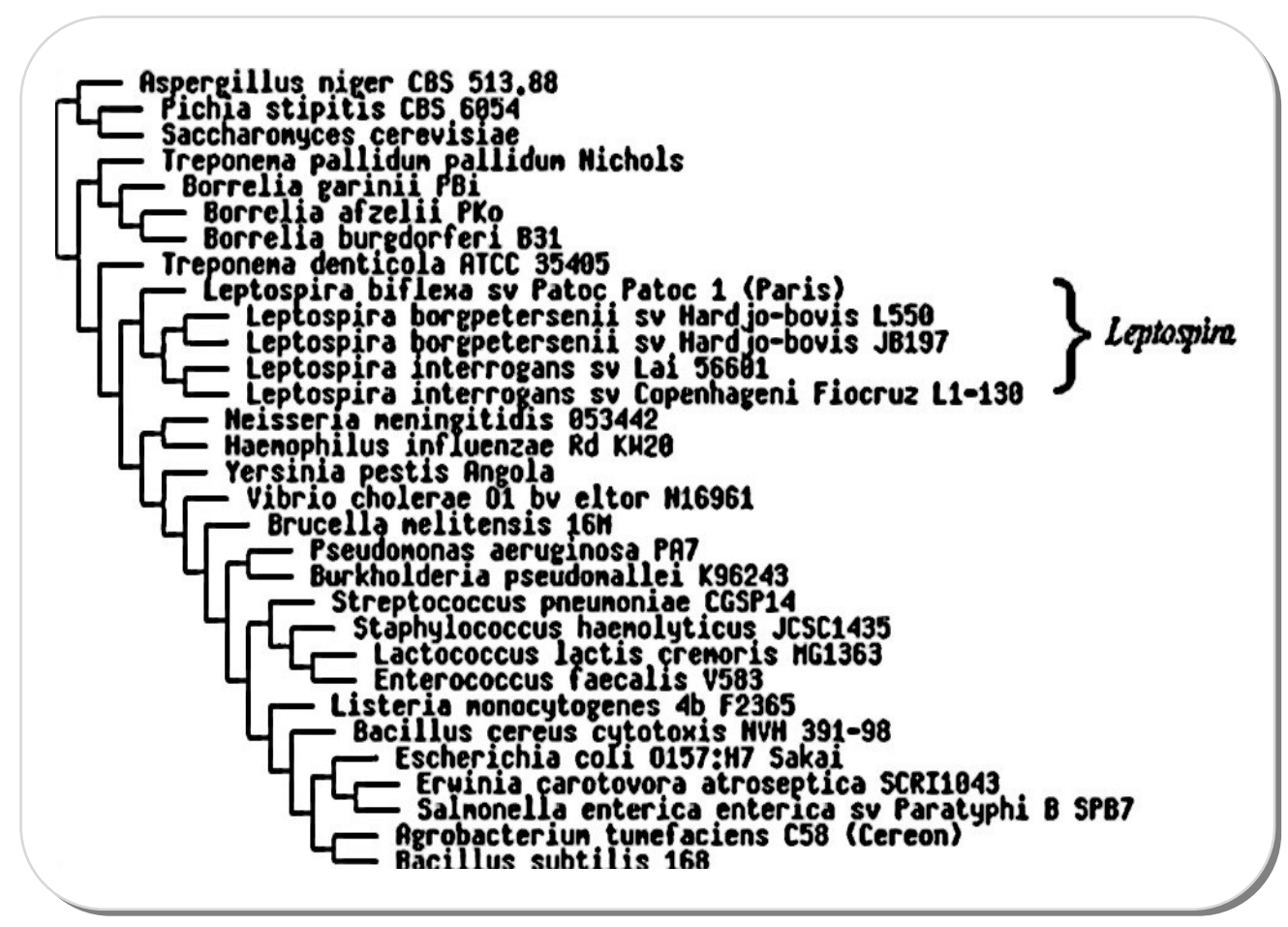

Figura 1.3 Estado evolutivo de Leptospira spp. Agrupamiento jerárquico de Clusters of Orthologous Groups (COGs) de proteínas (http://img.jgi.doe.gov/cgibin/w/main.cgi). Las especies fueron seleccionadas entre las secuencias genómicas completas disponibles. (Adaptado de Xue, 2008).

En 1989, basándose en una clasificación serológica, el género Leptospira fue dividido en dos especies: $L$. interrogans, que comprende todas las especies 
patogénicas y L. biflexa que abarca a todas las especies saprófitas de vida libre (Johnson and Faine, 1984). L. biflexa se diferencia de L. interrogans tanto en el crecimiento a $13^{\circ} \mathrm{C}$ como en el crecimiento en presencia de 8-azaguanina (225 $\mathrm{mg} / \mathrm{ml}$ ) y también en la forma esférica que adoptan las células de $L$. biflexa en presencia de $\mathrm{NaCl} 1 \mathrm{M}$.

Tanto L. interrogans como L. biflexa se dividen en numerosos serovares. Esta clasificación está basada en la expresión diferencial de los epitopes expuestos en la superficie, donde la especificidad del epitope depende de la composición y orientación del azúcar del lipopolisacárido.

Se reconocen alrededor de 60 serovares de L. biflexa (Johnson and Faine, 1984) y más de 200 serovares de L. interrogans. Los serovares antigénicamente relacionados se agrupan en serogrupos (Kmety and Dikken, 1993). Estos serogrupos no constituyen una unidad taxonómica pero son de gran utilidad para el entendimiento de la epidemiología. Los distintos serovares presentan cierta especificidad aunque no exclusividad en la preferencia por el huésped. Por ejemplo, el serovar Icterohaemorragiae prevalece en ratas, Ballum en ratones, Hardjo en bovinos, Pomona en cerdos y Canicola en perros.

Actualmente, y en base a estudios de homología de ADN, patrones de polimorfismo y tipificación de ARN ribosómico, la taxonomía del género Leptospira ha sido reorganizada en 19 genoespecies las cuales no se corresponden con la clasificación serológica y, más aún, serovares patógenos y no patógenos se encuentran en la misma especie.

En el año 2008, el Comité Internacional en Sistemática de Procariotas, agrupó a las especies de Leptospira en tres subgrupos. El primer subgrupo está constituido por las genoespecies saprófitas Leptospira biflexa, Leptospira wolbachii, Leptospira kmetyi, Leptospira vanthielii, Leptospira terpstrae y Leptospira yanagawae, todos microorganismos de vida libre en superficie y agua y no patogénicos para el hombre. El segundo grupo está integrado por 8 
genoespecies patogénicas: Leptospira interrogans, Leptospira kirschneri, Leptospira borgpetersenii, Leptospira santarosai, Leptospira noguchii, Leptospira weilii, Leptospira alexanderi y Leptospira alstoni. Por último, un tercer subgrupo reúne a todas las genoespecies de "comportamiento intermedio" cuyo rol en la patogenicidad aún no ha sido demostrado: Leptospira inadai, Leptospira broomii, Leptospira fainei, Leptospira wolffii y Leptospira licerasiae.

Más allá de la clasificación genética, la clasificación fenotípica (serológica) aún permanece vigente, debido a su gran utilidad, sobre todo con propósitos epidemiológicos.

\subsection{Epidemiología}

La leptospirosis ha sido recientemente categorizada como una enfermedad infecciosa reemergente que presenta una mayor incidencia en regiones tropicales y subtropicales y es causada por las especies patogénicas de Leptospira (Plank and Dean, 2000).

La leptospirosis en el pasado se asociaba mayormente con individuos cuyo lugar de trabajo o localización geográfica los colocaba en estrecha proximidad de animales salvajes o de cría (Stanchi, 2006). Sin embargo, en el presente se la asocia, en el caso de países desarrollados, con actividades de recreación (outdoors, trekkings, triathlons, etc.) (Plank and Dean, 2000), mientras que en los países en vías de desarrollo se ha vuelto prevalente en ciudades donde el rápido crecimiento poblacional y la falta de normas de urbanización por parte de las autoridades favorece la presencia de villas, con viviendas precarias, cada vez más grandes y con medidas sanitarias deficientes, que resultan en una población creciente de roedores, animales que actúan como reservorios y que contaminan el medio ambiente con su orina (Feigin and Anderson, 1975). 
La incidencia de la leptospirosis aumenta en épocas de lluvias e inundaciones, cuando ocurre contacto con agua contaminada por leptospiras patogénicas, eliminadas principalmente por la orina de roedores, aunque también puede ser por orina de perros, ganado o cerdos (Abb, 2002). Es por esto que también es considerada una enfermedad ocupacional ya que afecta a trabajadores de servicios sanitarios, cloacales, arrozales, bebederos, o aquellos que están en contacto con animales como los veterinarios, pastores, agricultores, matarifes y mineros entre otros (McBride et al., 2005).

\subsection{Reservorio}

La infección es común en roedores y otros animales tanto domésticos como silvestres. Como ya se mencionó, cada serovar tiene su o sus huéspedes predilectos, pero cada especie puede ser huésped de uno o más serovares (Faine et al., 1999).

En general, los roedores y animales silvestres no manifiestan síntomas o lesiones. En los animales portadores se produce una infección asintomática a nivel de los túbulos renales que trae como consecuencia que la bacteria se excrete en la orina por un largo período de tiempo (leptospiruria), contaminando así el agua y la tierra. A modo de ejemplo, una vaca puede eliminar $10^{7}$ leptospiras $/ \mathrm{ml}$ de orina durante varias semanas o meses. Los reservorios más eficaces, desde el punto de vista de la propagación bacteriana, son aquellos animales que tienen leptospiruria prolongada como los roedores (Hasnain and Ahmed, 2004). En contraste, la eliminación por orina en el ser humano es relativamente corta (Rossetti et al., 2003).

\subsection{Mecanismo de transmisión}

La transmisión de la infección del animal al hombre ocurre tanto por contacto de la piel, especialmente si ésta se encuentra erosionada, o de las 
mucosas de ojos y nariz, con agua, tierra húmeda o vegetación contaminadas con la orina de animales infectados (Figura 1.4). Este contagio puede ocurrir al nadar o inmersión accidental, por contacto directo con la orina o tejido de animales infectados en excoriaciones que pueden ser ocupacionales, o a veces, por la ingesta de alimentos contaminados con orina de ratas infectadas. Rara vez se produce por inhalación de aerosoles de líquidos contaminados y aún menos frecuentemente por la transmisión directa de persona a persona (Faine et al., 1999; Feigin and Anderson, 1975; Stanchi, 2006).

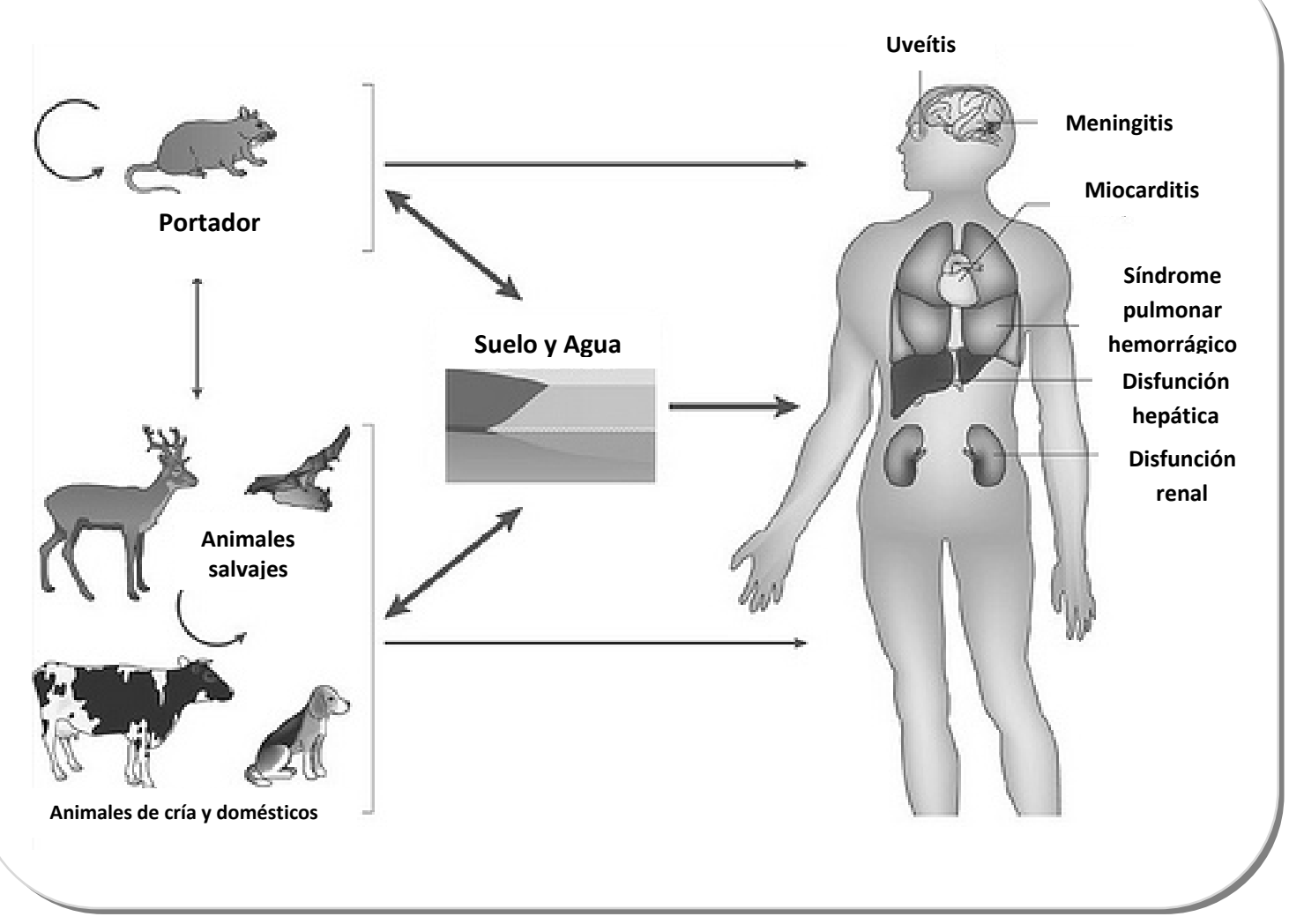

Figura 1.4 Ciclo de infección de Leptospira Los roedores actúan como portadores crónicos y asintomáticos contaminando suelo y agua con leptospiras y produciendo el contagio tanto de animales como del ser humano. Al penetrar estas a través de la piel erosionada o de las membranas mucosas entran a la circulación y se diseminan rápidamente hacia los tejidos blanco (Adaptado de Ko, 2009). 


\subsection{Historia Natural}

El período de incubación es alrededor de 10 días, con límites de 4 a 19 días. Permanece largamente subdiagnosticada debido en parte al gran espectro de signos y síntomas que los pacientes pueden presentar (Levett, 2001; Stanchi, 2006). Si bien suele ser autolimitada y sin secuelas, 5 al 15\% de los casos evolucionan de forma más severa, con una tasa de mortalidad variable entre el 5 al $40 \%$, presentando hemorragias y fallas renales y/o hepáticas, lo que se conoce como Síndrome de Weil (Rossetti et al., 2005; Stanchi, 2006). En los últimos años, ha sido cada vez más frecuente el compromiso pulmonar hemorrágico (Heisey et al., 1988; Plank and Dean, 2000).

En el curso natural de la leptospirosis se distinguen 2 fases: la septicémica o leptospirémica y la inmune o leptospirúrica (Figura 1.5). Entre ambas fases el paciente puede presentar alguna mejoría durante un periodo breve (1-3 días).

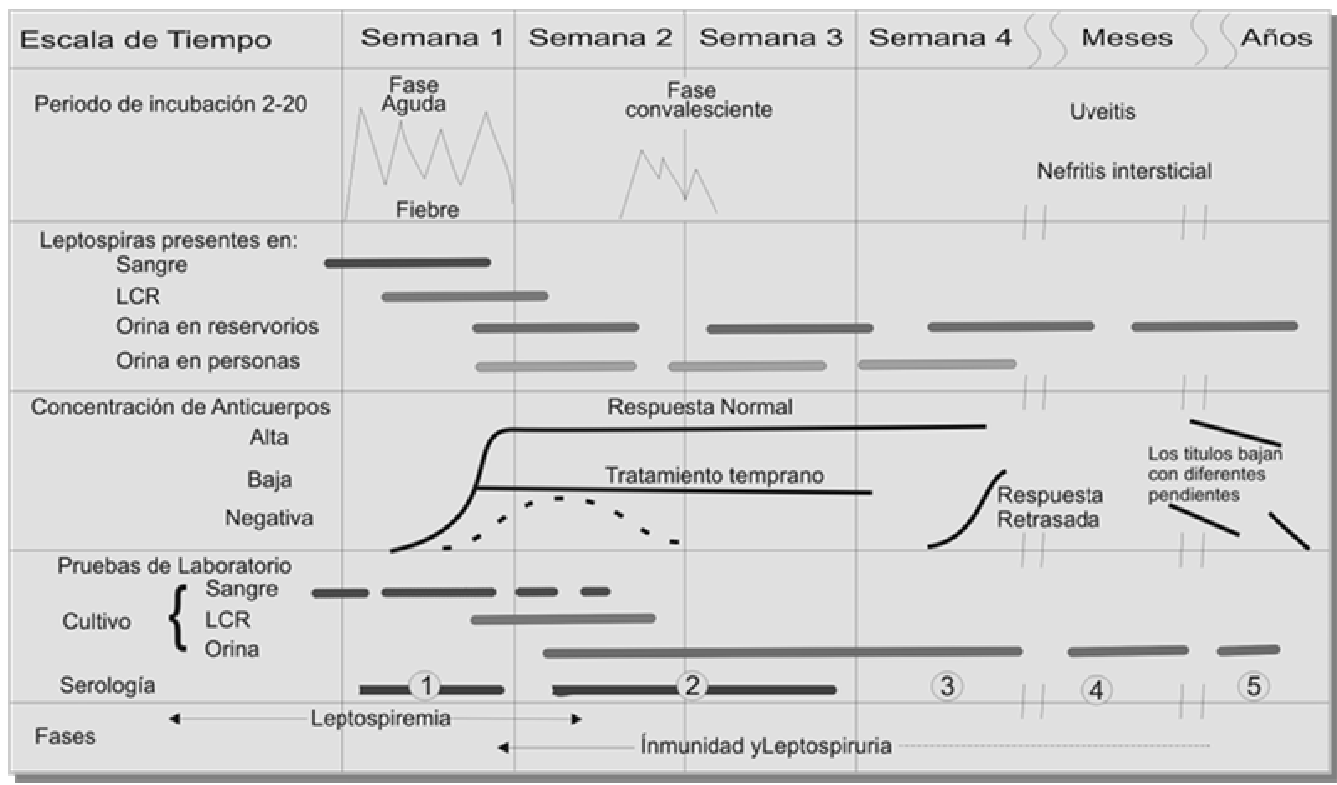

Figura 1.5 Naturaleza bifásica de la leptospirosis y sus características en la enfermedad en los diferentes estadios. La serología de las etapas 1 y 2 representan la fase aguda de la enfermedad; la de la etapa 3 la fase convaleciente lo que facilita la detección de la respuesta inmune y la de las etapas 4 y 5 son consideradas seguimientos de muestras que pueden tener valor (Adaptado de Turner, 1969). 
Primer estadio: esta fase es denominada septicémica o leptospirémica porque la leptospira puede ser aislada de cultivos a partir de sangre, líquido cefalorraquídeo (LCR) y otros tejidos. En esta etapa, que dura de 4 a 7 días, el paciente desarrolla una enfermedad no específica parecida a una gripe de variada intensidad. Se caracteriza por fiebre, escalofríos, debilidad y mialgias, afectando primariamente las pantorrillas, espalda y abdomen (Faine et al., 1999). Otros síntomas pueden ser dolor al tragar, tos, dolor en el pecho, erupción, hemoptisis, jaqueca, confusión mental, fotofobia y otros síntomas del síndrome meníngeo. Con frecuencia, el paciente puede referir exactamente cuándo fue el comienzo, ya que en esta enfermedad es característico el comienzo abrupto de los síntomas.

Entre ambos estadios hay un breve lapso que dura de 1 a 3 días donde el paciente presenta mejoría con descenso de la temperatura pudiendo estar asintomático. Luego la fiebre retorna indicando el comienzo de la segunda fase cuando se presenta una meningitis clínica o subclínica.

Segundo estadio: esta fase es denominada inmune o leptospirúrica porque se pueden detectar anticuerpos circulantes o el microorganismo puede ser aislado de la orina y ya no de sangre o del LCR. Esta etapa ocurre como consecuencia de la respuesta inmune del huésped y puede durar de 1 a 30 días o más. La enfermedad en esta etapa está referida a la afección de órganos específicos, incluyendo meninges, hígado, ojos y riñón. Síntomas no específicos como fiebre y mialgia son menos severos que en la primera fase y pueden durar de días a semanas. Alrededor del $75 \%$ de los pacientes experimentan jaquecas que no ceden ante analgésicos y que con frecuencia anticipa el comienzo de una meningitis.

A partir de este punto la enfermedad puede tomar dos presentaciones: anictérica o ictérica. En la primera el síndrome clínico más importante es la meningitis aséptica y a pesar de que usualmente dura pocos días, éste puede persistir hasta 1 o 2 semanas. La falta de síntomas específicos puede hacer que se sospeche de una meningitis viral. Con menor frecuencia aparecen cambios en la 
conciencia y/o encefalitis. Si bien los síntomas meníngeos se presentan en el 50\% de los pacientes, la muerte es extremadamente rara en la presentación anictérica de la enfermedad.

En la presentación ictérica de la enfermedad las leptospiras pueden ser aisladas de la sangre entre 24 y 48 horas luego del comienzo de la ictericia. Esta etapa puede ser acompañada por dolor abdominal, diarrea, constipación, hepatoesplenomegalia, nauseas, vómitos y pérdida del apetito. Entre el 2 al 10\% de los casos pueden presentar otras complicaciones como uveítis, que puede ocurrir concomitantemente con la enfermedad o hasta 1 año después (Vijayacharit et al., 2004; Wagenaar et al., 2004). Aunque la iridociclitis y la coriorretinitis pueden persistir por años, la hemorragia subconjuntival es la complicación oftalmológica más frecuente de la leptospirosis, ocurriendo en el 92\% de los pacientes. Las leptospiras pueden estar presentes en el humor acuoso.

Los síntomas renales tales como azotemia, piuria, hematuria, proteinuria y oliguria están presentes en el $50 \%$ de los pacientes con leptospirosis. Las leptospiras pueden estar presentes en el riñón. Las manifestaciones pulmonares pueden ocurrir entre el 20 y el 70\% de los pacientes (Guedes e Silva et al., 1980). En los últimos años el porcentaje de compromiso pulmonar parece haber aumentado en particular en su forma hemorrágica (Murdoch, 1980). También pueden observarse adenopatías, erupciones y dolor muscular.

Aunque no existe correlación entre síndromes clínicos y serotipos involucrados, se ha observado que la ictericia está presente en el $83 \%$ de los pacientes infectados con el serovar Icterohaemorrhagiae y en el 30\% de los pacientes infectados con Pomona. La erupción eritematosa pretibial puede ser observada en pacientes infectados con Autumnalis. En forma similar, los síntomas gastrointestinales predominan en pacientes infectados con Grippotyphosa. La meningitis aséptica ocurre más frecuentemente en pacientes infectados con Pomona o Canicola (Lee et al., 1981). 
La leptospirosis puede presentarse como una erupción macular o maculopapular, con dolor abdominal mimetizando una apendicitis aguda, o como adenopatía generalizada simulando una mononucleosis infecciosa. Otras presentaciones incluyen meningitis aséptica, encefalitis, o fiebre de origen desconocido.

La leptospirosis debe considerarse en un paciente que presente una enfermedad parecida a una gripe, con meningitis aséptica y mialgia.

\subsection{Síndrome de Weil}

El Sindrome de Weil es la forma severa de leptospirosis que se manifiesta primariamente como ictericia, con disfunción renal, necrosis hepática, disfunción pulmonar y diátesis hemorrágica (Seijo et al., 2002). Suele presentarse al final de la primera fase y se agudiza durante la segunda fase aunque la condición del paciente puede deteriorarse súbitamente en cualquier momento siendo la transición entre fases poco marcada. No existen criterios para anticipar quien desarrollará Síndrome de Weil. Las manifestaciones respiratorias incluyen tos, disnea, dolor torácico, hemoptísis y fallo respiratorio. Las disfunciones vasculares y renales acompañadas por ictericia se desarrollan de 4 a 9 días luego del comienzo de la enfermedad y la ictericia puede durar semanas. Los pacientes con severa ictericia son más propensos a desarrollar fallo renal, hemorragia y colapso cardiovascular (Goldstein et al., 2006). Durante la segunda semana puede existir hepatomegalia y necrosis tubular aguda con oliguria o anuria debido a la hipovolemia y la disminución de la perfusión renal. También puede presentarse fallo multiorgánico, rabdomiólisis (Kobayashi, 2001), síndrome de dificultad respiratoria del adulto (Dupont et al., 1997), hemólisis, esplenomegalia, insuficiencia cardíaca congestiva, miocarditis y/o pericarditis (Turhan et al., 2006). 


\subsection{Datos de laboratorio}

En la presentación moderada de la leptospirosis, puede observarse una elevada tasa de sedimentación y leucocitosis periférica (3.000-26.000 x ml). Las aminotransferasas, la bilirrubina sérica y la fosfatasa alcalina pueden encontrarse elevadas. En el examen de orina puede observarse proteinuria, leucocitos, eritrocitos y cilindros hialinos y granulares. Cuando existe compromiso del sistema nervioso central (SNC), el LCR puede presentar inicialmente leucocitos polimorfonucleares que son reemplazados más tardíamente por monocitos. El contenido de proteína puede ser normal o estar elevado, mientras que los niveles de glucosa y la presión sanguínea son normales.

En el Síndrome de Weil los pacientes pueden presentar: trombocitopenia, frecuentemente acompañada por fallo renal; azotemia; marcada leucocitosis; elevación del tiempo de protrombina; elevación de la creatina fosfoquinasa (CPK) con elevación moderada de las transaminasas y anormalidades del electrocardiograma (ECG); en casos severos puede ocurrir insuficiencia cardíaca congestiva y shock cardiogénico.

\subsection{Respuesta inmune}

La respuesta humoral puede ser detectable por MAT (del inglés, microscopic aglutination test) a partir de los 5 a 7 días posinfección (dpi), elevándose a su máximo en las siguientes semanas, permaneciendo de meses a años y pudiendo ser afectada por el tratamiento. Como determinante antigénico se destaca el lipopolisacárido leptospiral, y otros componentes de la membrana. La producción de IgG es inconstante. La especificidad de las inmunoglobulinas es generalmente de serovar. La fagocitosis por polimorfonucleares parece ser más lenta comparada con otras bacterias. 


\subsection{Patogénesis}

Luego de ingresar por piel o mucosas, el microorganismo se multiplica en la sangre y los tejidos. La leptospiremia resultante permite la diseminación a cualquier parte del cuerpo aunque afecta particularmente al hígado, los riñones y el pulmón.

La bacteria invade los sinusoides hepáticos, el espacio de Disse, y las células parenquimatosas. También invade el espacio entre estas últimas desestabilizando el canalículo y expulsando bilis a la circulación sistémica, con la consecuente hiperbilirrubinemia sin elevación concomitante de las enzimas hepáticas. Los sinusoides pueden desorganizarse o incluso obliterarse. Las células de Kuppfer se hinchan y pueden contener leptospiras y eritrocitos. Se ha descripto hemorragia focal y petequias, edema intersticial y focos necróticos (Arean, 1962; Miller and Wilson, 1966). Se ha comprobado que Leptospira puede inducir la apoptosis del hepatocito, lo cual limitaría la respuesta inflamatoria, permitiendo la proliferación microbiana en este órgano (Merien et al., 1998).

Es común el compromiso renal, que históricamente da cuenta de la mayor proporción de muertes por leptospirosis. Los hallazgos patológicos son consistentes con una nefritis intersticial, aunque la escasez de lesiones junto con el daño de la función renal sugiere que existe un daño intracelular mediado por toxinas. La vasculitis aguda y las hemorragias acompañan al edema intersticial, como así también la necrosis epitelial tubular y el deterioro de la membrana basal (Arean and Henry, 1964). Estos cambios se reflejan en un análisis urinario anormal, que frecuentemente muestra proteinuria, piuria, hematuria y formas hialinas y granulares. También se ve un incremento en los niveles de urea en suero y de creatinina.

El fallo renal en los pacientes se desarrolla frecuentemente con hipocalemia y sin oliguria, incluso poliuria. La hipocalemia y la poliuria sugieren un incremento en la secreción distal de potasio, posiblemente como resultado de una 
falla en la absorción en el túbulo proximal. La patogénesis renal también puede involucrar una endotoxina que inhibe la sodio/potasio ATPasa (Burth et al., 1997). La pérdida de potasio en la leptospirosis puede estar potenciada por un incremento sérico de aldosterona y cortisol (Abdulkader et al., 1996), y la poliuria puede exacerbarse debido a la resistencia de los ductos colectores a la vasopresina (Magaldi et al., 1992).

A nivel pulmonar puede observarse hemorragia pulmonar profusa. Los hallazgos incluyen petequias difusas y hemorragia a lo largo del tracto respiratorio, incluyendo tráquea, alvéolos e intersticio. Los vasos pulmonares muestran ampollas, descamación endotelial y trombos leucocitarios y plaquetarios; lesiones piramidales sugieren infarto hemorrágico. La hipoxia resultante puede empeorar el daño vascular y exacerbar la hemorragia. El edema pulmonar es más pronunciado en los casos que se presentan con miocarditis. Se pueden observar membranas hialinas en alvéolos y bronquíolos y raramente fragmentos leptospirales y organismos enteros (Arean, 1962). Frecuentemente existe un rápido deterioro respiratorio.

La leptospirosis comúnmente involucra al SNC. Entre los signos y síntomas figuran dolor de cabeza, fotofobia, visión borrosa, rigidez de la nuca y estado mental alterado. Estos hallazgos pueden ocurrir en ausencia de compromiso renal, hepático o pulmonar (Torre et al., 1994). También han sido reportados delirio, alucinaciones, encefalitis y coma (Heron et al., 1997). La meningitis aséptica se estima como complicación entre el 5 a 24\% de los casos (Lecour et al., 1989). El rasgo ocular más común en leptospirosis es la subfusión conjuntival benigna sin exudado la cual se autolimita. Poco frecuente, pero aún subdiagnosticada, la inflamación del tracto uveal puede presentarse como iritis, iridociclitis, corioretinitis y coroiditis, que incluyen fotofobia, visión borrosa y dolor.

El compromiso del músculo esquelético es común y no bien localizado, aunque las mialgias tienen predilección por las extremidades inferiores. La biopsia 
muscular muestra leptospiras y también hemorragia focal y degeneración sarcoplasmática (Arean and Henry, 1964) y a veces rabdomiólisis (Solbrig et al., 1987).

El compromiso cardíaco es común en la enfermedad severa y puede manifestarse como miocarditis, daño congestivo, y alteración no específica del electrocardiograma. También arritmias, generalmente fibrilación atrial y muerte súbita.

El compromiso gastrointestinal frecuentemente se acompaña de infección, anorexia, dolor, diarrea, hematemesis y hemorragia gastrointestinal fatal (Lecour et al., 1989).

Aun considerando las posibles severas complicaciones, la enfermedad es frecuentemente autolimitada y no es fatal (Chee et al., 1985). La respuesta inmune sistémica puede eliminar al microorganismo del cuerpo, pero también puede conducir a una reacción inflamatoria que produzca injuria tisular secundaria (Ho and Scully, 1980).

\subsection{Modelos animales}

Los cobayos y los hámsters son los animales más utilizados como modelo animal ya que reproducen una cinética de infección y severidad aún con inóculos bajos (menos de 100 leptospiras) similar a la observada en humanos (Silva et al., 2008). Los ratones y los gerbos han sido usados para estudiar la respuesta inmune (Pereira et al., 1998; Viriyakosol et al., 2006) pero los ratones son relativamente resistentes a la infección, aún con inóculos de $10^{6}$ leptospiras. Las ratas son usadas frecuentemente como modelo para el estudio de colonización persistente, pero también se requiere de un inóculo elevado (Athanazio et al., 2008; Nally et al., 2005). Aún no ha sido esclarecido el porqué si bien estos animales son reservorios naturales es tan costoso reproducir la infección experimentalmente. La infección 
natural es reproducida en primates, los cuales son utilizados para estudiar el desarrollo del síndrome pulmonar hemorrágico (Pereira et al., 2005).

\subsection{Diagnóstico}

La leptospirosis es una enfermedad de difícil diagnóstico clínico, ya que son frecuentes las enfermedades con síntomas similares a ella. Es necesaria una buena anamnesis que abarque los antecedentes personales de 15 a 20 días anteriores a la presentación de la enfermedad.

El diagnóstico de leptospirosis se realiza frecuentemente utilizando una combinación de evidencias clínicas, pruebas de laboratorio y las características epidemiológicas como ser: locación, temporada, lugar de trabajo, hábitat, contacto con animales, viajes a áreas endémicas, etc. Los síntomas más característicos para un diagnóstico temprano son: fiebre abrupta, dolores musculares, malestar general, eritrosedimentación elevada y la presencia de leucocitos y neutrófilos en orina.

El aislamiento de Leptospira puede realizarse desde sangre en los primeros 7 días ya que una vez que el sistema inmune es activado, los cultivos a partir de sangre pueden volverse negativos (las leptospiras permanecen viables en sangre anticoagulada hasta 11 días). También puede realizarse el aislamiento desde LCR a partir del $4^{\text {to }}$ y hasta el $10^{\text {mo }}$ día, durante la fase aguda de la enfermedad o desde orina a partir del $10^{\mathrm{mo}}$ día y permaneciendo por semanas, inclusive meses o años. Los cultivos de orina positivos pueden tomar hasta 8 semanas para crecer. Actualmente, se utilizan las técnicas de inmunofluorescencia indirecta y ELISA para detectar las leptospira en muestras clínicas y de necropsia (Shpilberg et al., 1990). 


\subsection{Pruebas serológicas}

El diagnóstico positivo se realiza por una elevación de 4 veces en los títulos de las pruebas serológicas, como el MAT. Un diagnóstico presuntivo puede realizarse cuando el título de anticuerpo es igual o mayor a 1:100 en el MAT en conjunto con síntomas consistentes con la enfermedad. En el MAT se utilizan una batería de 5 a 20 cepas de las leptospiras vivas más frecuentes en ese lugar, que se incuban con sueros para detectar anticuerpos aglutinantes. La información derivada de este ensayo es frecuentemente utilizada para identificar el serovar o variante de la leptospira patógena; sin embargo, son comunes las reacciones paradójicas y cruzadas entre serovares (Lai et al., 1982). Otros tests incluyen la hemaglutinación indirecta, el test de aglutinación microcapsular, detección de IgM específica por ELISA (del inglés, enzyme-linked immunoabsorbent assay), y la examinación de sangre u orina por campo oscuro. Más recientemente, se encuentran también disponibles test comerciales rápidos como el Dip-S-Ticks (PanBio, Maryland, USA), que detectan anticuerpos antileptospira. El ELISA, al detectar IgM, puede ser útil para el diagnóstico de nuevas infecciones dentro de los 3 a 5 primeros días. Sólo laboratorios especializados realizan el MAT, no debiendo retrasar el tratamiento, que se deberá comenzar mientras se esperan los resultados. Más recientemente y en forma creciente, se han propuesto numerosos protocolos de PCR para el diagnóstico y la identificación serotípica (Shivakumar and Shareek, 2004).

\subsection{Diagnóstico diferencial}

El diagnóstico diferencial debe hacerse con dengue, influenza, hepatitis vírica, fiebre hemorrágica viral, septicemia con ictericia o una variedad de enfermedades semejantes localmente prevalentes, incluyendo diversas enfermedades eruptivas, paludismo, fiebre de origen desconocido, rickettsiosis (fiebre $\mathrm{Q}$, tifus), borreliosis, brucelosis, toxoplasmosis, pielonefritis y fiebre 
amarilla. En pacientes que presentan meningitis debe hacerse un diagnóstico diferencial para establecer el origen viral o bacteriano (Levett, 2003).

\subsection{Tratamiento}

En general, el tratamiento es bajo internación hospitalaria. La hidratación parenteral es la base del tratamiento en especial en pacientes con shock donde la rehidratación debe ser agresiva y la deshidratación debe ser corregida en 6 a 24 horas. La reposición de fluidos debe continuar hasta que los niveles diuréticos sean corregidos. La orina producida por un paciente sospechoso de leptospirosis deberá ser coleccionada y considerada de riesgo biológico. Otras medidas incluyen control de signos vitales, monitoreo de la oximetría (valoración de la saturación de oxígeno) y rayos x. Esta última permite observar en radiografías pulmonares un patrón alveolar punteado en general en la periferia de los lóbulos inferiores que corresponde a hemorragia pulmonar, laboratorio de función renal y hepática y administración de antibióticos. En este caso, según el siguiente esquema para casos pediátricos: penicilina G $250.000 \mathrm{U} / \mathrm{Kg} /$ día por vía intravenosa (iv) fraccionado en cuatro dosis (cada 6 horas) durante 7 a 10 días. Tetraciclina en mayores de 9 años $40 \mathrm{mg} / \mathrm{Kg} /$ día, cada 6 horas vía oral (vo) por 7 a 10 días. En casos de adultos: penicilina sódica, 2 a 4 millones $U$ cada 6 horas iv por 7 días (droga de elección). Para aquellos alérgicos a la penicilina: cefotaxina de 1 a 2 gr. cada 8 horas por 7 días iv o intramuscular (im). Tetraciclina 500 mg cada 6 horas por 7 días vo. Doxiciclina $100 \mathrm{mg} 2$ veces al día vo por 7 días. Otros esquemas también son empleados. 


\subsection{Pronóstico}

La mayoría de los pacientes se recupera aún sin tratamiento. La tasa de mortalidad más alta se observa en pacientes ancianos $\mathrm{y} / \mathrm{o}$ en aquellos que desarrollan Síndrome de Weil. Las mujeres embarazadas presentan una alta tasa de mortalidad fetal o abortos espontáneos, en especial si la infección se contrajo durante los primeros meses de embarazo. Los pacientes con disfunción hepática y falla renal que sobreviven tienen altas chances de recobrar sus funciones normales hepáticas y renales en el largo plazo.

\subsection{Profilaxis}

La doxiciclina, en dosis de 200 mg/semana, ha demostrado ser eficaz en el 95\% de los casos de leptospirosis y puede ser administrada para prevenir la enfermedad en aquellas personas que han sido expuestas (Barocchi et al., 2001; Oliveira et al., 2003; Ooteman et al., 2006).

Las vacunas de uso veterinario disponibles actualmente están basadas en preparaciones totales de membrana inactivada de leptospiras patogénicas y parecen inducir una respuesta protectora a través de la inducción de anticuerpos antilipopolisacáridos de leptospira (Edwards and Levett, 2004). Sin embargo, estas vacunas fallan en inducir una protección de largo plazo y en proveer inmunidad protectora cruzada contra serotipos de leptospira no incluidos en la preparación vacunal. El gran número de serotipos patogénicos (>200) y el costo de producir una vacuna que contenga componentes de múltiples serotipos han sido factores limitantes mayores en el desarrollo de protocolos de inmunización basados en célula entera o en preparaciones de membrana. Las mismas limitaciones ocurren a la hora de desarrollar una vacuna licenciada para uso humano sumado a las reacciones adversas por emplear preparaciones totales de membrana (Krick, 1984). 
La vacunación a grupos de riesgo constituye una de las medidas de protección más útiles en el hombre para evitar la infección, unida a otras de carácter personal y ambiental. La inmunización humana contra el riesgo de exposiciones ocupacionales a serovares específicos se ha utilizado con diversos resultados en Italia, Japón, Polonia, Israel, Francia, Rusia y China (Iagovkin et al., 1990; Torten et al., 1973). En Cuba se logró producir una vacuna bacteriana trivalente (vax-SPIRAL) que contiene los tres serogrupos de leptospiras patógenas que con mayor frecuencia circulan en ese país (Canicola, Pomona e Icterohaemorragiae) causando la enfermedad en el humano (Bourzac et al., 2005). Desde 1997, el preparado de células inactivadas de leptospira, adsorbidas en un gel de hidróxido de aluminio, brinda una protección superior al $70 \%$ de los inmunizados y su aplicación está recomendada en personas con riesgo de exposición a partir de los 15 años de edad.

No existe una vacuna licenciada de uso humano ni tampoco existen vacunas de uso veterinario basadas en antígenos recombinantes, es decir, altamente homogéneos, confiables y eficaces, por lo que cabe inferir que dichos productos tendrían una demanda importante de parte del mercado local e internacional y por lo tanto servirían para generar patentes de alto impacto económico (Faine et al., 1999; Levett, 2001).

\subsection{Medidas de control}

Entre la medidas de control pueden mencionarse la notificación de todos los casos a la autoridad correspondiente; el aislamiento del paciente y precauciones respecto a la sangre y los líquidos corporales de las personas enfermas; la desinfección concurrente de los artículos contaminados con orina; la investigación de todos los casos, contactos y de la probable fuente de infección. 


\subsection{Vigilancia epidemiológica}

Es una enfermedad que probablemente se pasa por alto y por ende esta subnotificada en muchos países, debido al difícil diagnóstico clínico y a la falta de laboratorios de diagnóstico. La OMS recomienda la inmediata notificación de casos sospechosos o confirmados a nivel periférico (en hospitales o laboratorios), debiéndose investigar todos los casos. La vigilancia con base en hospitales permite obtener así información sobre los casos más graves. La serovigilancia indica las variedades prevalentes.

La definición de caso recomendada corresponde a enfermedad febril aguda con cefalea, mialgia y postración asociada a: subfusión conjuntival, irritación meníngea, anuria u oliguria, proteinuria, ictericia, hemorragias (intestinal, pulmonar), arritmias o insuficiencia cardíaca, erupción cutánea y el antecedente de exposición a animales infectados o a un ambiente contaminado con orina de animales. El criterio recomendado para dar a un caso confirmado como positivo corresponde a aquel que es confirmado por un laboratorio competente, mediante aislamiento o serología positiva.

\subsection{Prevalencia e incidencia en la República Argentina}

En la República Argentina, la incidencia en la población humana ronda el $18 \%$ de positividad serológica frente a Leptospira spp. cuando se evalúan sueros de pacientes sospechosos. Mientras que en pacientes no sospechosos, el porcentaje varía entre el 2 y el $6 \%$. Aproximadamente, el $28 \%$ de los casos clínicos detectados corresponde a áreas densamente pobladas, lo que la clasifica como una importante zoonosis urbana de notificación obligatoria que puede presentarse tanto en forma esporádica como en brotes epidémicos (Stanchi, 2006). 
Los brotes más importantes ocurridos en nuestro país fueron en 1976 (Buenos Aires), 1998 (Santa Fe), 2003 (Entre Ríos) y 2007 (Santa Fe) (Figura 1.6), éste último ha sido el más importante, reportándose más de 400 casos. En los primeros 2 meses del año 2010 se informaron 32 casos en la provincia de Santa Fe, 6 de los cuales resultaron fatales.

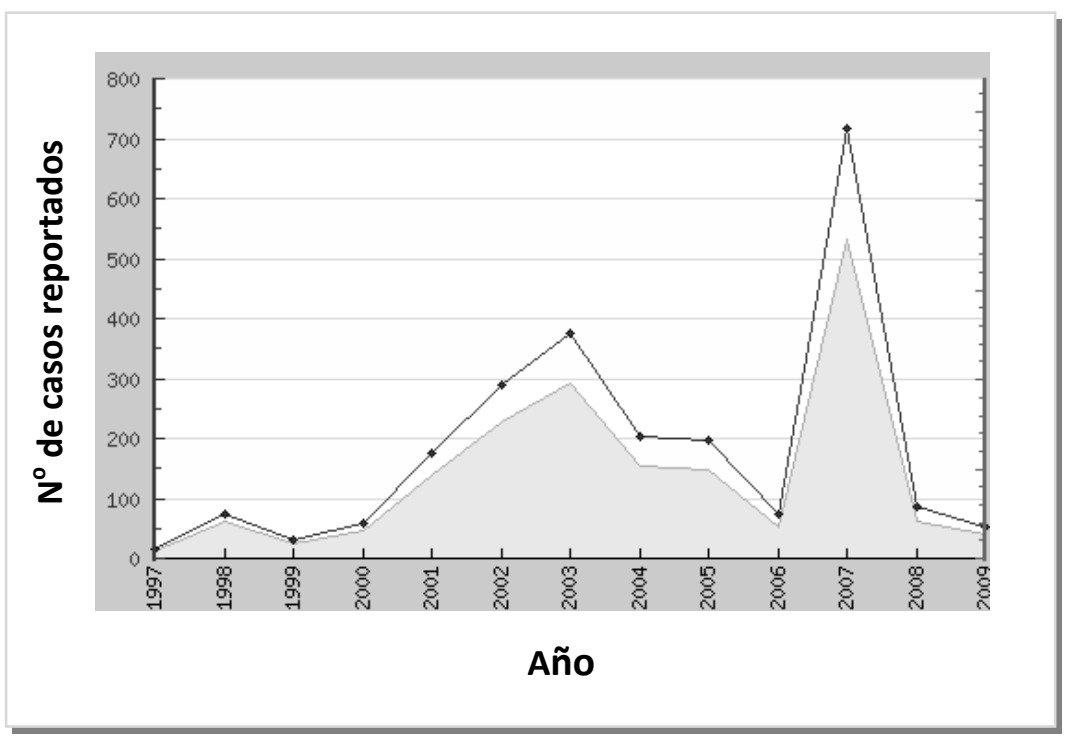

Figura 1.6 Casos reportados de leptospirosis en nuestro país desde 1997 hasta el año 2009. La mayoría de los casos fueron informados en Gran Buenos Aires y en las Provincias de Santa Fe, Entre Ríos, Córdoba y Neuquén (Guideon data base).

Durante la década del 70, se identificaron 12 serovares distintos en los pacientes infectados, aunque los serovares más frecuentes fueron Bratislava, Icterohaemorrhagiae y Butembo. En el periodo 1984-1994 el 41\% de los casos fue debido a L. interrogans serovar Canicola.

En nuestro país los reservorios más comunes son las ratas, los cerdos, caballos y los perros. Del $25 \%$ al $40 \%$ de las ratas y del $10 \%$ al $60 \%$ de los perros en Buenos Aires son seropositivos, frecuentemente a los serovares Canicola y Pyrogenes. 


\subsection{Impacto socio-económico}

La leptospirosis es un problema económico de suma importancia para la salud pública así como para la industria agropecuaria, ya que en los pacientes el tratamiento requiere hospitalización y frecuentemente diálisis renal (Alfonso et al., 2005; Koizumi and Watanabe, 2005), mientras que en el ganado induce abortos, partos prematuros, infertilidad, reducción de la producción de leche, pérdida de peso y hasta muerte (Koizumi and Watanabe, 2005).

Como la leptospirosis produce en el ganado una infección crónica, la industria agropecuaria sufre una pérdida económica adicional cuando se aplican a nivel nacional y/o internacional regulaciones de cuarentena.

Por la correlación directa con la situación económica y al afectar a países agroexportadores, no sorprende que tenga un fuerte impacto en un país como la Argentina. 


\section{Objetivos}

\section{Objetivo general}

El propósito general de este trabajo es:

1. Generar herramientas moleculares que sean útiles contra la leptospirosis, ya sea para su diagnóstico, prevención o un mejor conocimiento de su patogénesis.

2. Estudiar mecanismos patogénicos involucrados en la leptospirosis.

\section{Objetivos específicos}

1. Clonado, expresión y purificación de proteínas recombinantes.

2. Producción de antisuero contra las proteínas recombinantes.

3. Análisis de reactividad entre suero de pacientes y las proteínas recombinantes.

4. Caracterización de actividades biológicas de las proteínas recombinantes incluyendo la capacidad de inducir activación endotelial y de inhibir la apoptosis de polimorfonucleares.

5. Estudiar el papel de la óxido nítrico sintasa inducible (iNOS) en la leptospirosis. 


\section{Capítulo 2 Proteínas Recombinantes}

Herramientas moleculares para diagnóstico, prevención y estudios patogénicos de la leptospirosis 


\subsection{Introducción}

El advenimiento del secuenciamiento completo de los genomas ha tenido un impacto enorme en el campo de la biología molecular. El secuenciamiento completo del genoma del serogrupo B de Neisseria meningitidis permitió generar nuevas estrategias para la identificación de candidatos vacunales, dejando atrás las técnicas tradicionales aplicadas durante más de 4 décadas (Pizza et al., 2000).

De este modo surgió la vacunología reversa (reverse vaccinology), que consiste en la predicción de antígenos in sílico, sin la necesidad de purificar el antígeno del microorganismo (Adu-Bobie et al., 2003). Esta técnica ha sido aplicada en los últimos años y ha revolucionado el área de investigación en vacunas.

Desde hace relativamente poco tiempo se conoce el genoma de seis especies de Leptospira, patogénicas y no patogénicas, Estas especies son: L. interrogans serovar Lai cepa Lai, L. interrogans serovar Copenhageni cepa Fiocruz L1-130, L. borgpetersenii serovar Hardjo-bovis cepas L550 y JB197, y Leptospira biflexa serovar Patoc cepas Patoc I (Paris y Ames) (Tabla 2.1) (Bulach et al., 2006) (Nascimento et al., 2004b; Picardeau et al., 2008; Ren et al., 2003). Estas tres especies de Leptospira son representativas de diferentes estilos de vida: L. biflexa no es patogénica y es un organismo de vida libre que habita en el agua y en los suelos mientras que $L$. interrogans y $L$. borgpetersenii son los principales agentes de la leptospirosis y causantes de enfermedad severa tanto en animales como en humanos. Sin embargo, L. interrogans es capaz de sobrevivir en el medio ambiente, incrementando de este modo el riesgo de transmisión de la enfermedad, mientras que L. borgpetersenii no puede sobrevivir fuera de su huésped (Bulach et al., 2006). 
Tabla 2.1. Especies secuenciadas de Leptospiras hasta el momento (Xue et al., 2009).

\begin{tabular}{cccccc}
\hline Especies & Cepa & Serogrupo & Serovar & Origen & $\begin{array}{c}\text { Huésped o } \\
\text { fuente }\end{array}$ \\
\hline L. interrogans & Lai 56601 & Icterohaemorrhagiae & Lai & China & Humano \\
L. interrogans & $\begin{array}{c}\text { Fiocruz L1- } \\
130\end{array}$ & Icterohaemorrhagiae & Copenhageni & Brasil & Humano \\
L. borgpetersenii & L550 & Sejroe & Hardjo & Australia & Humano \\
L. borgpetersenii & JB197 & Sejroe & Hardjo & USA & Ganado \\
L. biflexa & $\begin{array}{l}\text { Patoc I } \\
\text { (Paris) }\end{array}$ & Semaranga & Patoc & Italia & Agua de arroyo \\
L. biflexa & Patoc I & Semaranga & Patoc & Italia & Agua de arroyo \\
& (Ames) & & & & \\
\hline
\end{tabular}

Tanto L. interrogans como L. borgpetersenii tienen dos cromosomas circulares y ambos genomas están caracterizados por un alto grado de plasticidad genómica, con evidencia de rearreglos genómicos a gran escala. La diferencia más marcada entre $L$. interrogans y $L$. borgpetersenii es el mayor número de pseudogenes, secuencias de inserción y secuencias residuales en esta última (Tabla 2.2).

Tabla 2.2 Comparación de los genomas de tres especies de leptospira (Adler and de la Pena Moctezuma, 2010).

\begin{tabular}{cccc}
\hline & L. borgpetersenii & L. interrogans & L. biflexa \\
\hline Tamaño $(\mathrm{kb})$ & 3931 & 4627 & 3956 \\
Número de genes & 2844 & 3379 & 3590 \\
Porcentaje codificante (\%) & 80 & 75 & 92 \\
Número de pseudogenes & 368 & 41 & 33 \\
Número de transposasas & 246 & 26 & 9 \\
\hline
\end{tabular}

El análisis comparativo de las 2 especies patogénicas y la saprófita muestra la presencia de 2052 genes en común constituyendo el core genómico leptospiral (Figura 2.1), sugiriendo un origen común para las tres especies. El análisis comparativo también permite identificar genes específicos de las especies patógenas. La proporción de genes que codifica para proteínas de función desconocida es del $40 \%$. Sin embargo, este tipo de genes forman parte de los genes específicos de cada especie patogénica. De los 627 genes únicos de $L$. interrogans, más de 500 (80\%) codifica para proteínas hipotéticas. Para L. 
borgpetersenii más de 200 de un total de 265 (75\%) genes únicos codifican para proteínas de función desconocida. Estos datos son consistentes con el hecho de que Leptospira posee factores de virulencia propios que no han sido identificados por similitud con otras bacterias.

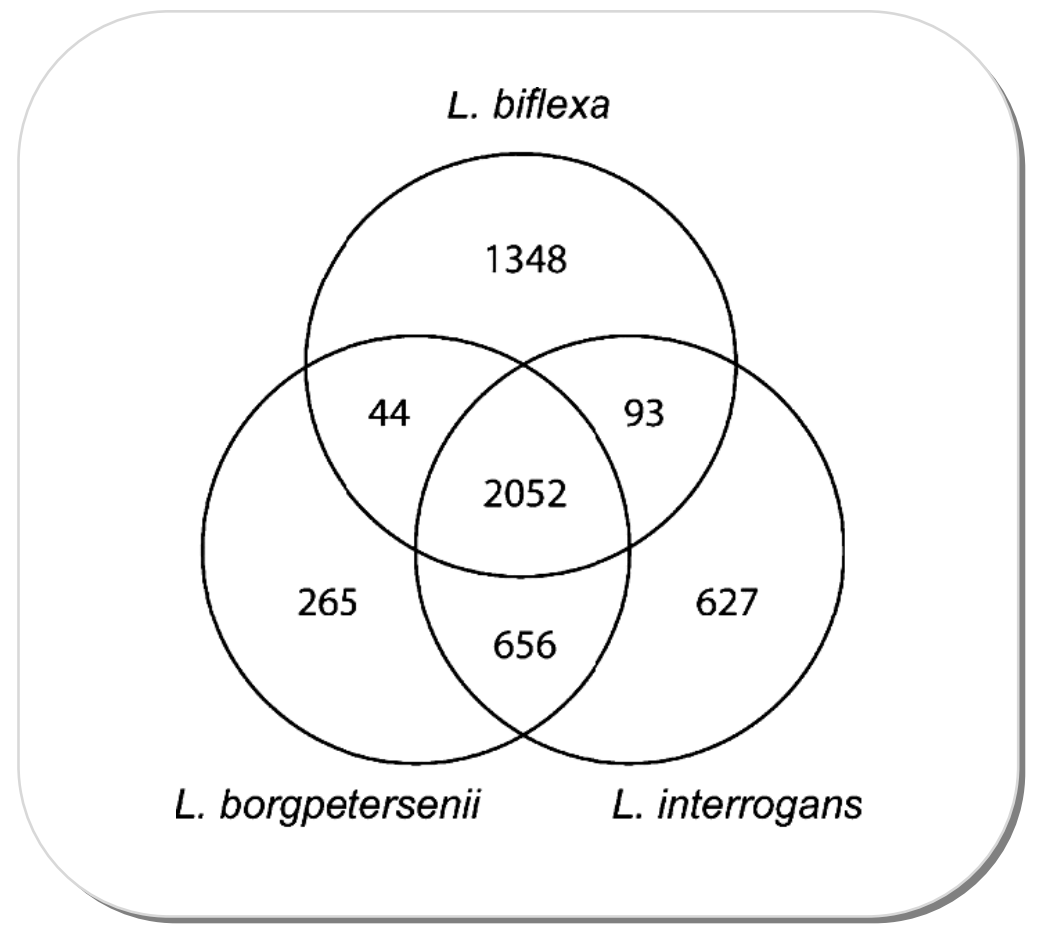

Figura 2.1 Análisis comparativo de los genomas de las dos especies patogénicas de Leptospira, interrogans y borgpetersenii y la saprófita biflexa. Los números representan los ORF detectados (Adler and de la Pena Moctezuma, 2010).

El genoma de Leptospira interrogans serovar Copenhageni cepa Fiocruz L1-130, LIC, fue totalmente secuenciado por el Consorcio AEG-Agronomical \& Environmental Genomes/ONSA/FAPESP, bajo la coordinación general de la Dra. Ana Lucia Tabet Oller do Nascimento (Centro de Biotecnología Molecular, Instituto Butantán). Las secuencias han sido depositadas en el GenBank bajo los números de acceso AE016823 (cromosoma I) y AE016824 (cromosoma II). El genoma de $L$. interrogans consiste en 2 cromosomas circulares con un total de 4, 627, 366 pares de bases (bp), correspondiendo 4, 277, 185 bp al cromosoma I y 350, 181 bp al cromosoma II (Figura 2.2). 


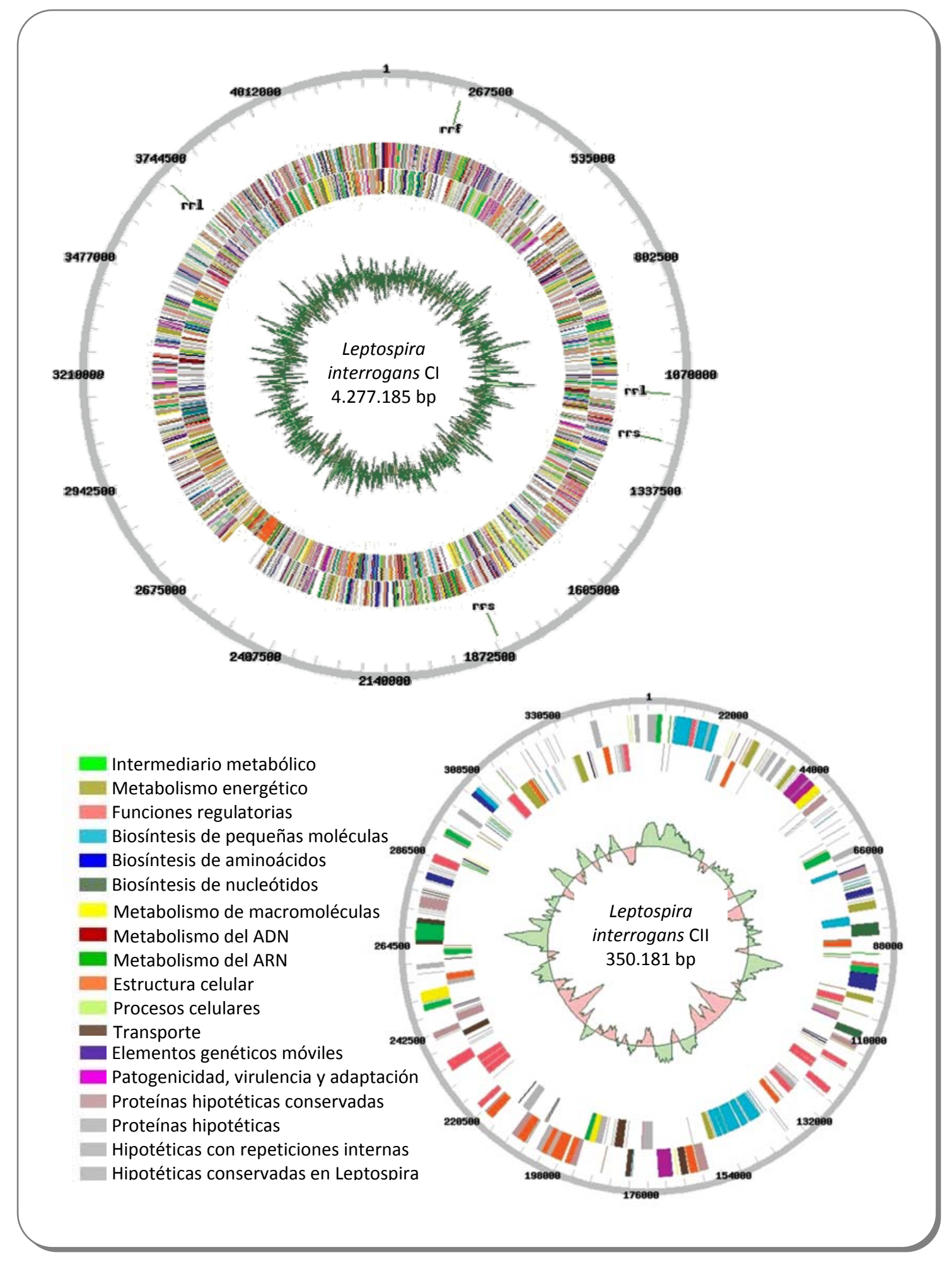

Figura 2.2 Mapa circular de los dos cromosomas de Leptospira interrogans. Círculo 1 y 2 (de afuera hacia adentro), muestran todas las regiones codificantes (hebra directa y complementaria) en distintos colores según su función; círculo 3: contenido de $\mathrm{G}+\mathrm{C}$. Los números del círculo externo indican las pares de bases. Los genes del ARNr, rrl, rrs y rrf corresponden a la subunidad 23S, $16 \mathrm{~S}$ y $5 \mathrm{~S}$. Nota: Los dos replicones no han sido dibujados a escala. El tamaño del cromosoma II (CII) es 12 veces menor con respecto al cromosoma I (CI) (Nascimento et al., 2004b). 
El origen de replicación del replicón mayor se encuentra entre los genes dnaA y dnan como en los genomas de otras bacterias. El análisis del contenido de G y $\mathrm{C}$ en cada hebra de ADN confirma la posición del origen de replicación del replicón mayor e indican dos sitios putativos para el replicón menor. Los genes $A R N r$ en $L$. interrogans no se organizan en operones como en la mayoría de las bacterias si no que están dispersos por todo el cromosoma. LIC posee un gen rrf, dos rrs para la subunidad 5S, 235 y $16 S$ del ARNr, respectivamente. Los genes que codifican enzimas de diversas vías metabólicas como la glucólisis y el ciclo de Krebs y vías biosintéticas de aminoácidos y cofactores, se encuentran distribuídos entre ambos cromosomas. En el cromosoma II se encuentra presente un grupo de genes cuyo productos intervienen en la biosíntesis del grupo hemo, (hemAIBCENYH), un grupo de 13 genes esenciales para la biosíntesis de la cobalamina (cobC, cobD, cbiP, cobP, cobB, cobO, cobM, cobJ, cbiG, cobl, cobL, $c o b H, c o b F)$ y $m e t F$, que codifica a la metilenotetrahidrofolato reductasa.

En el cromosoma I se encuentra cysG, un gen que codifica para una proteína multifuncional con actividad metilasa, oxidasa y ferroquelatasa, y cobA, cobT/cobU, cobS que participan en la biosíntesis de la vitamina B12. De hecho se ha comprobado que las leptospiras pueden crecer en un medio desprovisto vitamina B12, contrario a lo que se sostenía anteriormente.

También existe un gran número de genes que codifica para transportadores primarios, impulsados por la hidrólisis de ATP (transportadores $A B C)$, y transportadores secundarios impulsados por el potencial electroquímico transmembrana. Otros genes codifican enzimas con actividad catalasa, glutatión peroxidasa y tiolperoxidasas las cuales proveen un sistema de defensa contra el daño oxidativo. Dos bacterioferritinas codificadas por los genes lic11310 y lic13209 se encargan tanto de la detoxificación como el almacenamiento de hierro. Muchos genes de $L I C$ codifican señales de transducción lo que demuestra un vasto sistema de regulación capaz de responder a las señales del entorno. Además, posee un amplio número de genes comprometidos en la movilidad y en 
la quimiotaxis y un grupo de genes que codifican hemolisinas, las cuales jugarían un papel muy importante en los procesos tóxicos. Las leptospiras patogénicas poseen un alto número de proteínas expuestas en su superficie implicadas en la colonización y supervivencia dentro del huésped. Entre estas proteínas de membrana encontramos porinas no específicas, canales específicos de entrada de nutrientes, canales de flujo de salida, lipoproteínas, adhesinas, glicoproteínas, proteínas de membrana periférica, y proteínas de mantenimiento de superficie. El genoma leptospiral contiene homólogos de $\operatorname{Sec} Y$ y de otras proteínas secretorias involucradas en el transporte de proteínas con péptido señal a lo largo de la membrana citoplasmática. También contiene los genes que codifican para una peptidasa señal estándar y una peptidasa señal de lipoproteínas. En LIC se han identificado 184 lipoproteínas de membrana externa (OMPs del inglés, outer membrane proteins).

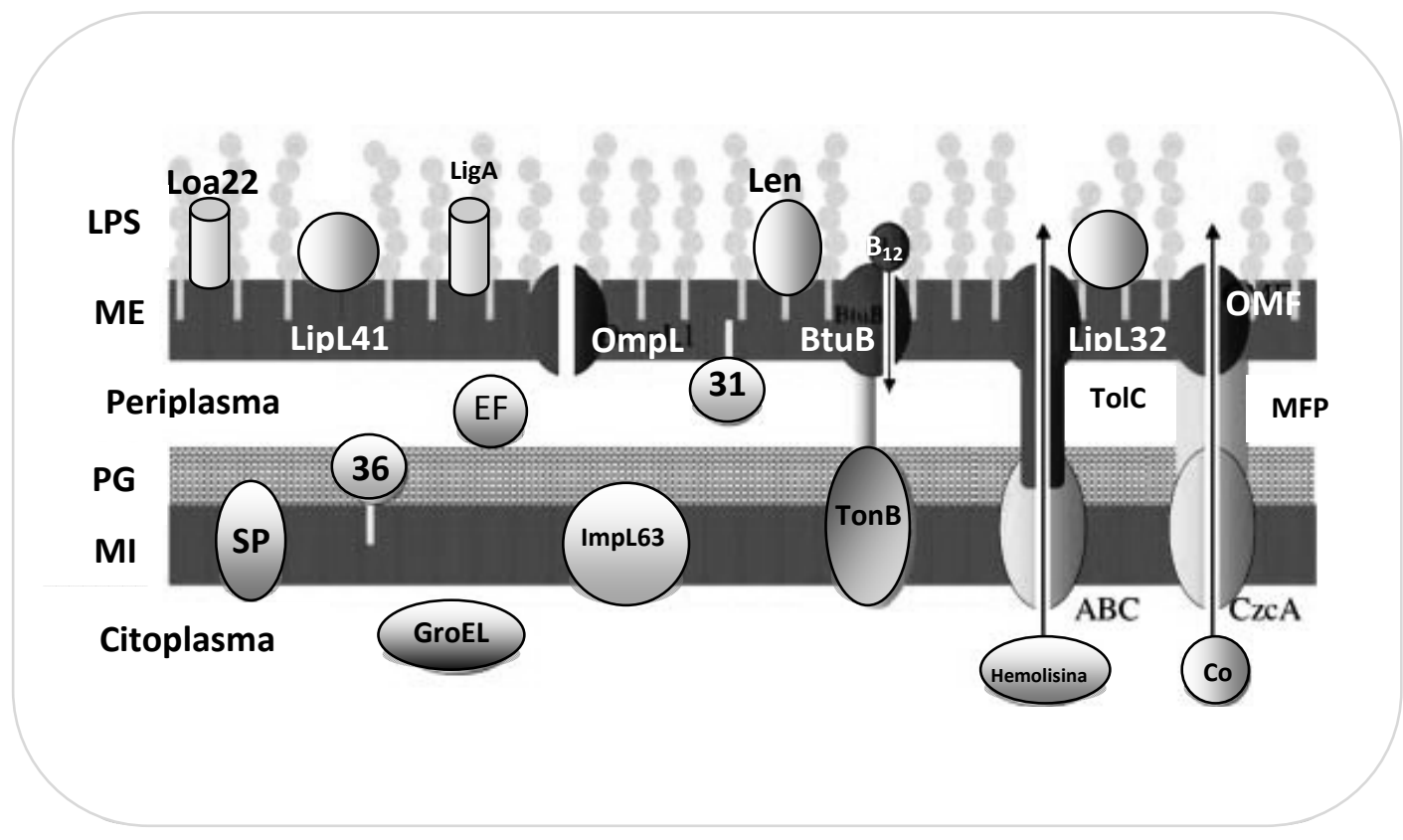

Figura 2.3. Modelo de la arquitectura de la membrana leptospiral. La superficie leptospiral está dominada por las cadenas laterales de los carbohidratos del lipopolisacárido (LPS). Las proteínas citoplasmáticas incluyen GroEL, y el endoflagelo periplásmico. La membrana interna (MI) contiene lipoproteínas como LipL31, la peptidasa señal (SP) e ImpL63. La membrana externa (ME) contiene lipoproteínas como LipL41, Loa22, LigA, LenA, LipL36, LipL32, OmpL1, OMPs dependientes de TonB, responsables de la adquisición de nutrientes, como BtuB y otras tal como TolC que son transportadores responsables de la salida de componentes citoplasmáticos. Se muestra el factor de membrana externa (OMF), la proteína de fusión de membrana (MFP), y un trasportador interno (CzcA) involucrado en la detoxificación de metales pesados (Nascimento et al., 2004b). 


\subsection{Justificación de los candidatos seleccionados}

La lesión principal en la leptospirosis se relaciona con el daño producido en los capilares y pequeños vasos (Faine et al., 1999). Algunos investigadores creen que una o varias toxinas bacterianas podrían jugar un papel importante en la progresión de la enfermedad. Varias proteínas fueron identificadas como potenciales candidatos vacunales, y algunas de ellas están relacionadas con la patogénesis de la enfermedad (Nascimento et al., 2004a). La mayoría de ellas son lipoproteínas como colagenasas, metaloproteasas, termolisinas y adhesinas, con dominios similares tanto a inmunoglobulinas como a integrinas. En este sentido, un amplio rango de moléculas celulares puede funcionar como receptores para la adhesión de la bacteria al huésped (Nascimento et al., 2004b). Las proteínas de superficie se consideran el primer contacto por el cual el microorganismo interactúa y se adhiere a los tejidos del huésped. Esta unión parece ser un primer estadio esencial en el establecimiento de la infección de varios patógenos bacterianos.

Las moléculas de adhesión o CAMs (del inglés, cell adhesion molecules) son receptores celulares de superficie presentes en células eucariotas que median las interacciones célula-célula o célula-matriz extracelular. Un número significativo de bacterias patógenas invaden los tejidos del huésped a través de su habilidad de unirse a las CAMs (Gomez et al., 2008). Además del esperado efecto del lipopolisacárido de la pared, se ha observado en Borrelia spp. y Treponema spp. la activación del endotelio vascular por OMPs con el consecuente aumento de la expresión de distintos receptores de adhesión (Boyle and Finlay, 2003; Finlay and Cossart, 1997; Kerr, 1999).

Las lipoproteínas son actualmente consideradas de gran interés en la búsqueda de candidatos vacunales y marcadores diagnóstico (Lee et al., 2000; Lee et al., 2005; Sellati et al., 1996; Sellati et al., 1995; Shamaei-Tousi et al., 2000). Algunas lipoproteínas de espiroquetas ya han sido aisladas y estudiadas como OspA de Borrelia burgdorferi (Bunikis and Barbour, 1999), SmpA de Brachyspira 
hiodysenteriae (Thomas and Sellwood, 1993), LipL32 de Leptospira interrogans (Haake et al., 2000), y Tpp47 de Treponema pallidum (Weigel et al., 1994). Existe en la actualidad una vacuna licenciada en los EUA que utiliza la lipoproteína OspA para prevenir la enfermedad de Lyme causada por la espiroqueta Borrelia burgdorferi (Poland and Jacobson, 2001). Además, las lipoproteínas pueden activar al sistema inmune innato a través de receptores Toll-like (Yoder et al., 2003). Se demostró que existe sinergismo en la protección de animales contra leptospirosis utilizando 2 proteínas externas, OmpL1 y LipL41 (Haake et al., 1999). Otros estudios mostraron que el suero de pacientes convalecientes reaccionaban con LipL32, LipL41 y otras 2 proteínas de 62 y 76 kDa identificadas como proteínas de shock térmico (Gamberini et al., 2005). Se ha sugerido que estas proteínas podrían servir como marcadores diagnósticos. En conjunto, estos datos indican que las lipoproteínas de $L I C$ son de gran importancia como candidatos vacunales y marcadores diagnóstico.

Como ya se ha mencionado, en la secuenciación del genoma de LIC se han identificado 184 lipoproteínas, siendo conocidas al momento de comenzar este estudio menos de 20. Entre las lipoproteínas nuevas, muchas son hipotéticas, es decir que no se han identificado homólogos en otros organismos. En la divergencia entre las secuencias lipoproteicas espiroquetales y las de otras bacterias se encuentra implicada una región consenso en el péptido señal denominada lipobox (Figura 2.4). A partir de estas secuencias es posible concluir que las lipoproteínas espiroquetales son secretadas a través de la membrana citoplasmática vía péptido señal pero el extremo c-terminal del lipobox difiere significativamente de una a otra especie bacteriana. Las diferencias en la secuencia del lipobox dan como resultado diferencias en la especificidad de sustrato en el sitio activo de la gliceriltransferasa y la peptidasa señal tipo II, que transfiere un grupo diacilgliceril hacia una Cys y remueve el péptido señal, respectivamente (Paetzel et al., 2002). 
Todas las OMPs leptospirales estudiadas hasta la fecha fueron sintetizadas con un péptido señal en su extremo N-terminal, el cual inicia la exportación de la proteína con el posterior clivaje del mismo. Si bien los péptidos señal no comparten secuencias homólogas, todos comparten cierta forma estructural. Los péptidos señal en general poseen entre 1 y 3 cargas positivas en su extremo $\mathrm{N}$ terminal seguido de una mezcla de entre 9 y 15 residuos neutros e hidrofóbicos y un sitio consenso de clivaje para la peptidasa señal (von Heijne, 1985). Los péptidos señal de las lipoproteínas son clivados por una peptidasa señal específica de lipoproteínas (Lsp) y las OMPs transmembrana lo son por una peptidasa líder (Lep); por lo tanto, los respectivos péptidos señal poseen secuencias señal consenso para sus correspondiente enzimas (Hayashi and Wu, 1990). Ala-X-Ala en las posiciones 3 a 1 son las secuencias más comúnmente observadas que preceden al sitio de clivaje reconocido por Lep, junto con pequeños aminoácidos de cadenas laterales neutras (von Heijne, 1986). Las lipoproteínas seleccionadas en este proyecto se listan en la Tabla 2.3.

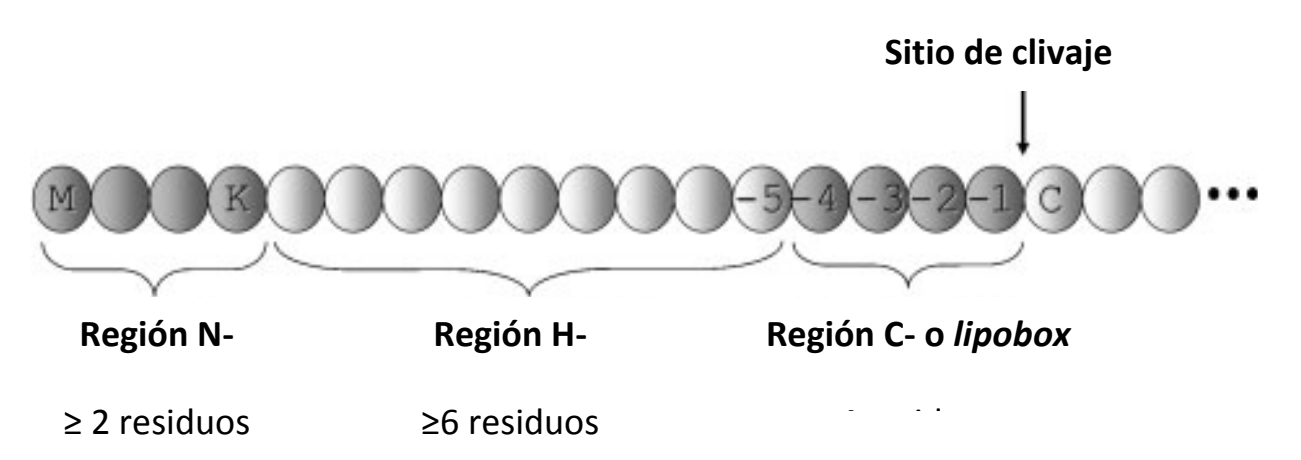

Figura 2.4 Esquema de las regiones aminoacídicas del péptido señal. La región N-terminal abarca desde la metionina de inicio hasta el último residuo cargado. La región H-hidrofóbica se extiende desde el último residuo cargado y debe tener al menos 6 aminoácidos de longitud. La región C-terminal o lipobox contiene 4 aminoácidos de longitud donde la posición 1 es ocupada por Ser, Asn, Ala, Gly, Cys, Thr o Gln y la tercer o cuarta debe contener al menos Leu, Phe, Val, lle o Tyr. Los residuos cargados tales como Lys, Arg, Asp, Glu e His no están permitidos tanto en la región H-como en la C- (Setubal et al., 2006). 
Tabla 2.3 Genes seleccionados de LIC que codifican para potenciales proteínas. El peso molecular las proteínas están expresados en kilodaltons.

\begin{tabular}{cccccc}
\hline Gen & Similaridad & Nts & AA & MW & Péptido Señal \\
\hline LIC11207 & Lipoproteína & 1092 & 364 & 37.99 & $1-19$ \\
LIC12690 & Lipoproteína & 2526 & 842 & 94.41 & $1-16$ \\
LIC12922 & Lipoproteína & 1089 & 363 & 42.34 & $1-46$ \\
\hline
\end{tabular}

Datos preliminares indican que las probables lipoproteínas LIC11207 y LIC12690 son reactivas al suero de ratas inmunizadas con extractos de Leptospira. Por otro lado, LIC12922 fue reconocida por los anticuerpos presentes en suero de hámsters infectados experimentalmente. Por esta razón decidimos incluir LIC11207, LIC12690 y LIC12922 en este trabajo. 


\subsection{Resultados}

\subsubsection{Cultivo de diferentes especies de leptospiras}

Se realizó el cultivo de 8 especies de leptospiras patogénicas: Leptospira interrogans serovar Canicola, Grippotyphosa, Icterohaemorrhagiae, Copenhageni y Pomona; Leptospira borgpetersenii serovar Hardjo, Ballum y Tarassovi y el de una especie saprófita: Leptospira biflexa serovar Patoc. El crecimiento bacteriano se detectó por turbidez en los medios líquidos y por la formación de un anillo de crecimiento (zona de Dinger) en los medios semisólidos EMJH luego de 15 días a 30 으, en aerobiosis y en oscuridad (Figura 2.5A). También se observó una ligera turbidez hacia arriba y hacia abajo del anillo (Figura 2.5B). El crecimiento fue confirmado por medio de preparaciones húmedas observadas con un microscopio de campo oscuro (Figura 2.5C).

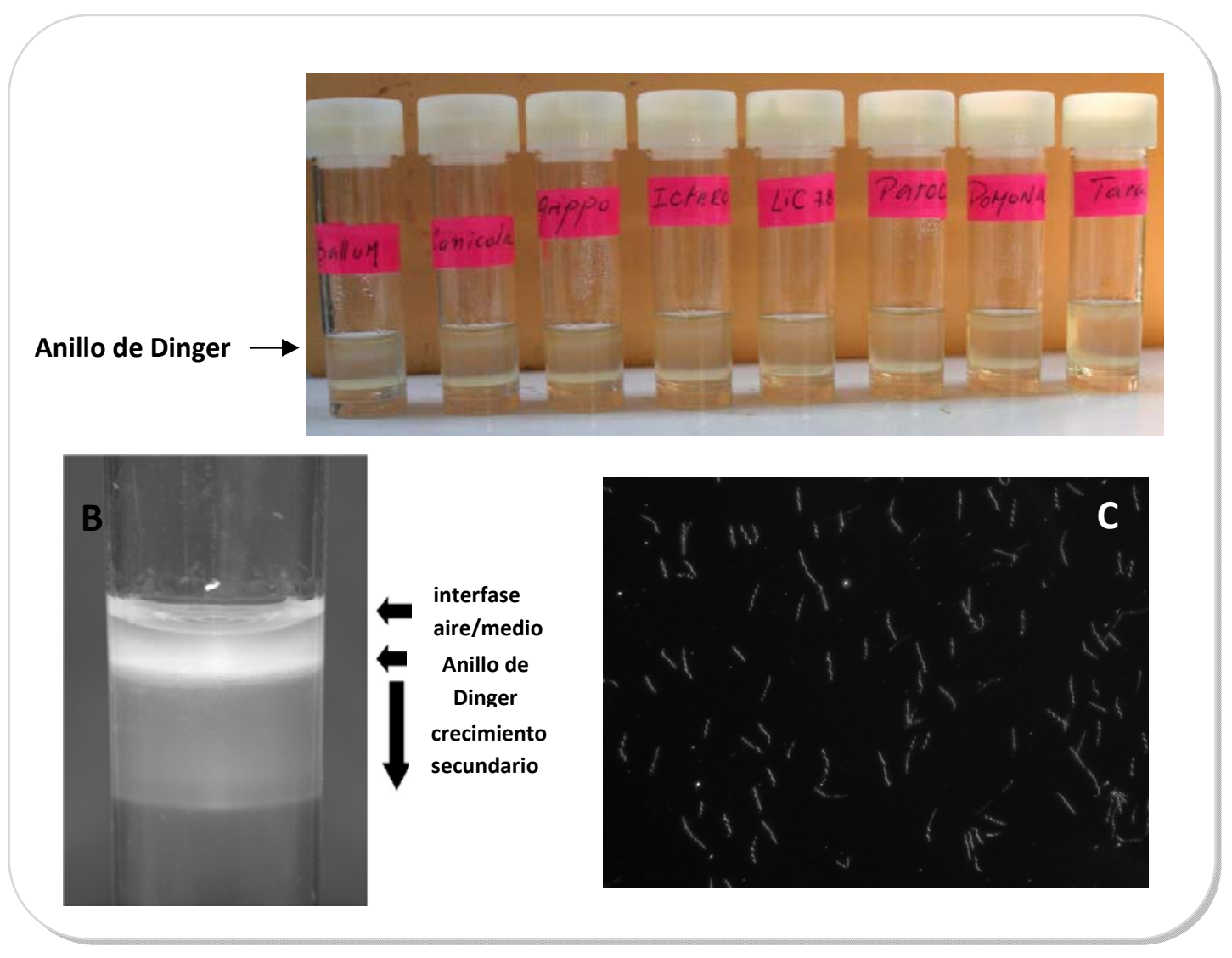

Figura 2.5 Crecimiento de distintas especies de Leptospira. A. Cultivo de 15 días en medio EMJH semisólido. Puede observarse el anillo de crecimiento (zona de Dinger). B. Ligera turbidez hacia arriba y hacia abajo del anillo. C. Microscopía de campo oscuro mostrando leptospiras en suspensión. 


\subsubsection{Análisis bioinformático de la secuencia de LIC12690, LIC11207 y LIC12922}

Los genes que codifican para LIC12690, LIC11207 y LIC12922 fueron identificados en el cromosoma I mediante el análisis de los probables ORFs presentes en el genoma de L. interrogans serovar Copenhageni (Nakai and Horton, 1999; Nascimento et al., 2004a). Basándose en la búsqueda de motivos secuenciales en el servidor PSORT (Nakai and Kanehisa, 1991b) se encontró que LIC12690 es prevista como una proteína de membrana externa (>90\%), LIC12922 se encuentra en el espacio periplásmico (>90\%) y LIC11207 fue prevista como una proteína de membrana externa/interna. Los servidores DAS y TOPpred predijeron un dominio transmembrana para LIC12690 y LIC11207 y ninguno para LIC12922. Se encontró la presencia de un péptido señal en las 3 proteínas analizadas mediante el uso de los servidores LipoP y SignalP (Emanuelsson et al., 2007; Juncker et al., 2003) y estos acordaron en que LIC12690 es una lipoproteína con sitio de clivaje para la peptidasa señal II en los aminoácidos 16 y 17; LIC11207 contiene un sitio de clivaje para esta misma enzima en los aminoácidos 18 y 19 y LIC12922 un sitio de clivaje en los aminoácidos 46 y 47 . El análisis por BLAST mostró que LIC12690 posee entre un 17 y $23 \%$ de identidad con otras proteínas tipo endostatinas leptospirales, la superfamilia LEN. Tanto las proteínas LEN como LIC12690 contienen un dominio en común de función desconocida (DUF1554) de acuerdo con el servidor PFAM (Finn et al., 2006). Se identificaron dominios similares conservados de LIC12690 en L. interrogans serovar Lai (99\% de identidad) (Ren et al., 2003), pero ausentes en las secuencias de L. borgpetersenii (Bulach et al., 2006) y L. biflexa (Picardeau et al., 2008). En cuanto a LIC11207 se encontró que esta posee un dominio DUF1565 de acuerdo a PFAM y el análisis por BLAST indica que dominios similares fueron identificados en $L$. interrogans serovar Lai (98\% de identidad), en L. borgpetersenii (62\% de identidad) pero ausentes en L. biflexa.

LIC12922 contiene un dominio común a la superfamilia de las rotamasas, un dominio prsA, de peptidilprolil-isomerasa y un dominio SurA de peptidilprolil- 
isomerasa tipo parvulina. Se identificaron dominios conservados de LIC12922 en L. interrogans serovar Lai ( $100 \%$ de identidad), en L. borgpetersenii ( $89 \%$ de identidad) y L. biflexa (48\% de identidad) como así también en otras espiroquetas. Los resultados obtenidos se muestran en la tabla 2.4 .

Tabla 2.4. Análisis bioinformático de LIC12690, LIC11207 y LIC12922.

\begin{tabular}{|c|c|c|c|}
\hline & LIC12690 & LIC11207 & LIC12922 \\
\hline $\begin{array}{l}\text { Localización } \\
\text { (pSORT) }\end{array}$ & Membrana externa & $\begin{array}{c}\text { Membrana } \\
\text { externa/interna }\end{array}$ & $\begin{array}{c}\text { Espacio } \\
\text { periplásmico }\end{array}$ \\
\hline $\begin{array}{l}\text { Péptido Señal } \\
\text { (LipoP y SignalP) }\end{array}$ & $\begin{array}{l}\text { Clivaje en } \\
\text { aas } 16 \text { y } 17\end{array}$ & $\begin{array}{l}\text { Clivaje en } \\
\text { aas } 18 \text { y } 19\end{array}$ & $\begin{array}{l}\text { Clivaje en } \\
\text { aas } 46 \text { y } 47\end{array}$ \\
\hline $\begin{array}{c}\text { Dominios } \\
\text { Transmembrana } \\
\text { (DAS y TOPpred) }\end{array}$ & uno & uno & ------- \\
\hline $\begin{array}{l}\text { Dominios } \\
\text { Funcionales } \\
\text { (PFAM) }\end{array}$ & DUF1554 & DUF1565 & $\begin{array}{l}\text { Rotamasas } \\
\text { prsA } \\
\text { SurA }\end{array}$ \\
\hline $\begin{array}{l}\text { Homología } \\
\text { (BLAST) }\end{array}$ & $\begin{array}{c}\text { L. interrogans sv Lai } \\
\text { Familia LEN, edostatinas } \\
\text { leptospirales }\end{array}$ & $\begin{array}{l}\text { L. interrogans sv Lai } \\
\qquad \text { L. borgpetersenii }\end{array}$ & $\begin{array}{l}\text { Leptospira spp. y } \\
\text { otras espiroquetas }\end{array}$ \\
\hline
\end{tabular}

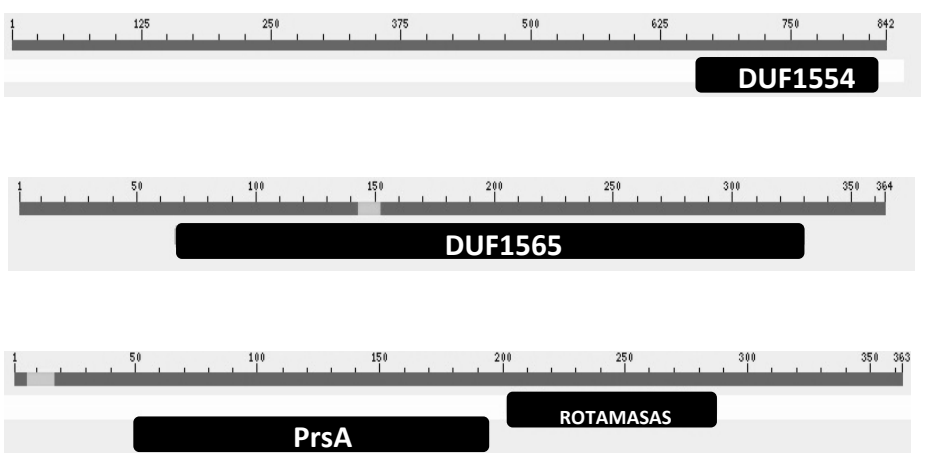

LIC12690

LIC11207

LIC12922

Figura 2.6 Esquema de los dominios funcionales presentes en LIC12690, LIC11207 y LIC12922. 


\subsubsection{Comparación de secuencias de LIC12690, LIC11207 y LIC12922 con otras}

adhesinas leptospirales reportadas

Para evaluar el grado de similitud de las proteínas LIC12690, LIC11207 y LIC12922 con otras proteínas de unión a la ECM previamente identificadas en la misma especie (Barbosa et al., 2006; Hauk et al., 2008; Stevenson et al., 2007), se realizó un alineamiento usando el algoritmo ClustalX (Setubal et al., 2006; Thompson et al., 1997). Los resultados se dispusieron en forma de árbol donde distancias menores indican una mayor relación entre proteínas (Figura 2.7). Podemos observar que LIC11207 agrupa con proteínas de la familia LEN, las cuales son endostatinas leptospirales, mientras que LIC12690 y LIC12922 no agrupan con esta superfamilia.

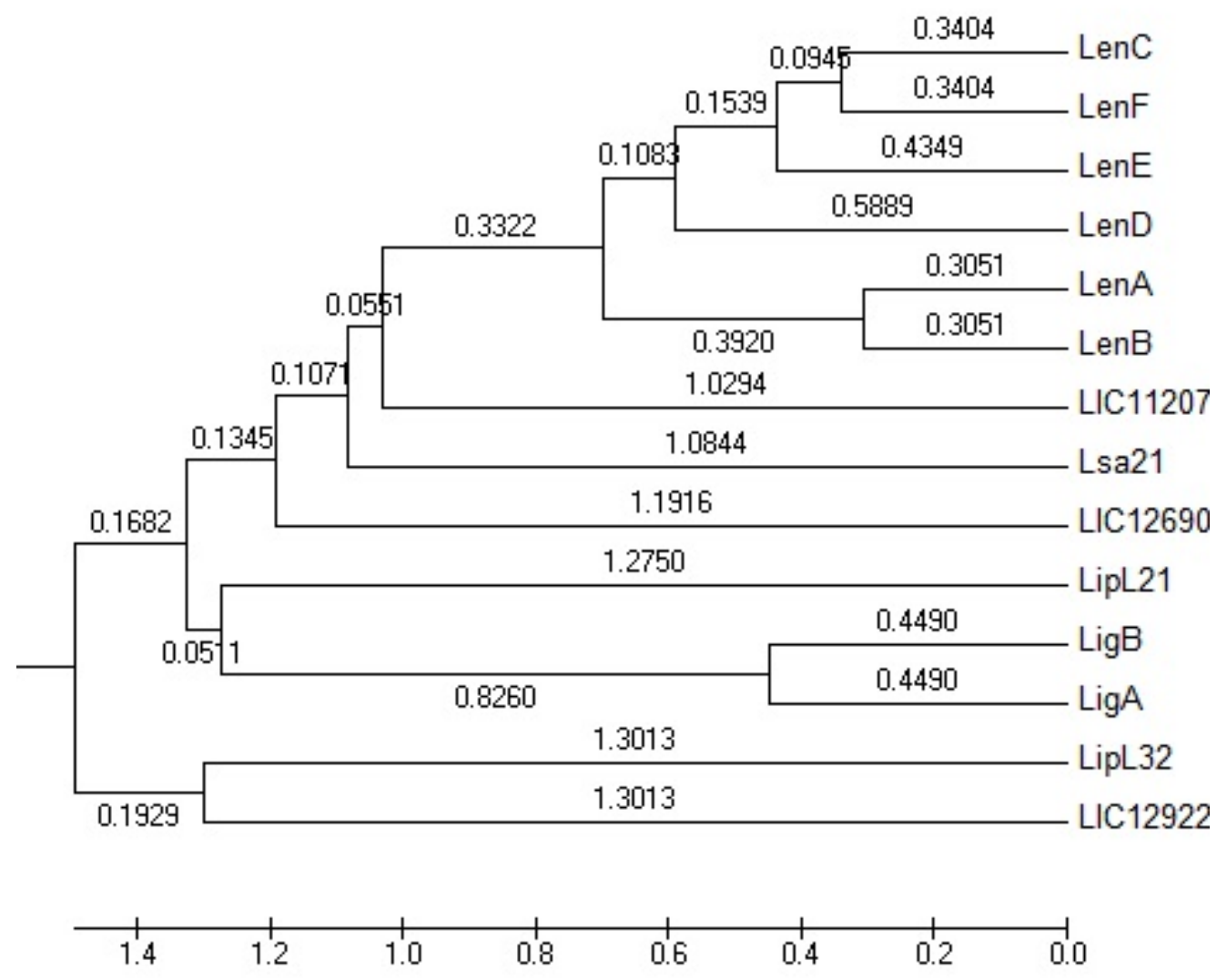

Figura 2.7 Análisis comparativo entre LIC12690, LIC11207, LIC12922 y otras proteínas leptospirales previamente reportadas, tales como las de la familia Len, LigA/LigB, Lsa21, LipL21 y LipL32. El alineamiento fue realizado con el programa ClustalX y el árbol de similitud fue generado con el Mega5. En la figura se muestran las distancias. 
2.3.4 Distribución del gen lic12690, lic11207, lic12922 entre las distintas especies de leptospira

La presencia de los genes lic12690, lic11207 y lic12922 fue examinada en ocho especies patogénicas y en una saprófita de Leptospira por PCR empleando pares de primers diseñados en base a la secuencia genómica de $L$. interrogans serovar Copenhageni. Un fragmento de ADN con un tamaño de 399pb correspondiente al gen lic12690 fue amplificado en cuatro de las especies patogénicas de L. interrogans (serovares Canicola, Copenhageni, e Icterohaemorrhagiae) y L. borgpeterseni serovar Hardjo. No se detectó dicho producto en las especies pertenecientes a los serovares Grippotyphosa, Pomona y tampoco en la especie no patogénica $L$. biflexa serovar Patoc (Figura 2.8A). Un fragmento de ADN con un tamaño de $855 \mathrm{pb}$ perteneciente al gen lic11207 fue amplificado en cuatro de las especies patogénicas de L. interrogans (serovares, Copenhageni, Icterohaemorrhagiae, Canicola y Pomona). No se detectó dicho producto en las especies de $L$. Interrogans serovar Grippotyphosa y $L$. borgpetersini serovar Ballum y Tarassovi y tampoco en la especie saprófita $L$. biflexa serovar Patoc (Figura 2.8B). Un fragmento de ADN con un tamaño de 880pb pertenecientes al gen lic12922 fue amplificado en todas las especies de leptospira spp. (Figura 2.8C). Con el fin de verificar la integridad del templado se llevó a cabo la amplificación de un fragmento de 331pb correspondiente al gen que codifica el ARNr16S (Figura 2.8D).

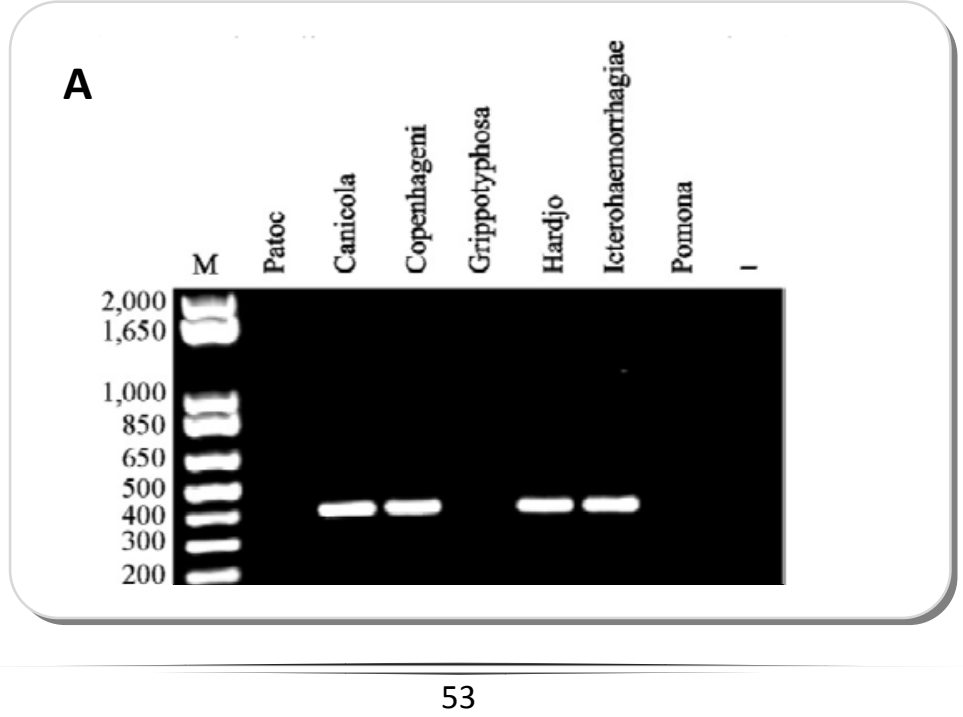




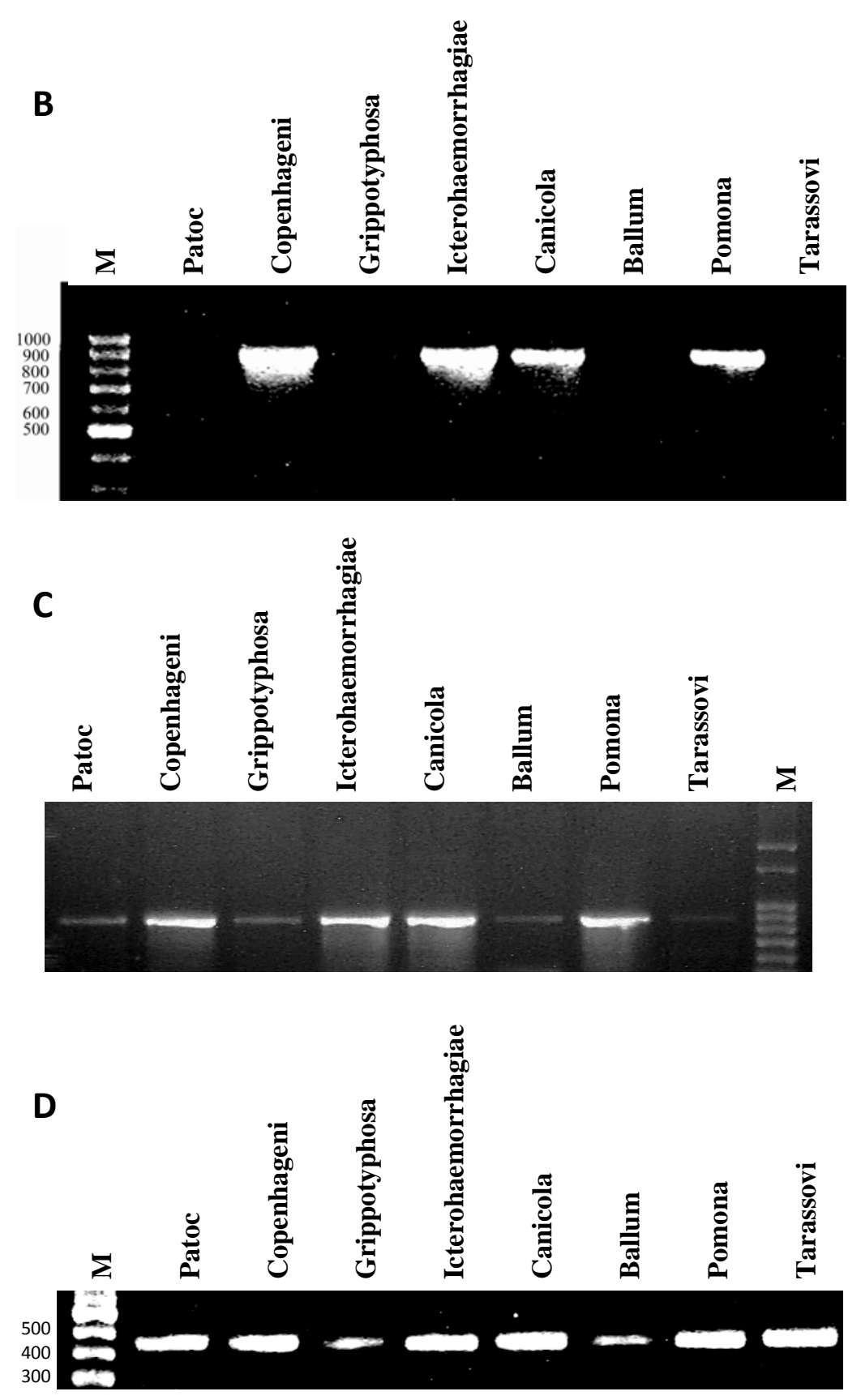

Figura 2.8 Distribución de los genes lic12690, lic11207 y lic12922 en especies patogénicas de leptospiras y en la especie saprófita Análisis por PCR del ADN genómico de L. biflexa serovar Patoc y de ocho serovares patogénicos de L. interrogans usando primers específicos para lic12690 (A), lic11207 (B) y lic12922 (C). La amplificación de un fragmento de $331 \mathrm{pb}$ del gen ARNr16S muestra la integridad del templado (D). El tamaño esperado del producto de PCR es 399pb, $855 \mathrm{pb}$ y $880 \mathrm{pb}$ para los fragmentos pertenecientes a lic12690, lic11207 y lic12922, respectivamente. Como control negativo se empleó una muestra sin el agregado de ADN. M: marcador de peso molecular. 
2.3.5 Análisis transcripcional de los genes lic12690, lic11207 y lic12922 entre las distintas especies de leptospiras

La expresión de lic12690, lic11207 y lic12922 en cultivos de leptospiras fue evaluada por transcripción reversa seguida de la reacción en la cadena de la polimerasa (RT-PCR). Los resultados obtenidos revelaron la presencia de los transcriptos de lic12690 en las especies L. interrogans serovares Canicola, Copenhageni, Hardjo e Icterohaemorrhagiae mientras que L. interrogans serovares Grippotyphosa y Pomona y en la especie no patogénica L. biflexa serovar Patoc no se encontró la presencia del mismo (Figura 2.9A). El transcripto de lic11207 fue encontrado en L. interrogans serovares, Copenhageni, Icterohaemorraghie, Canicola y Pomona pero no lo fue en las especies pertenecientes a los serovares Grippotyphosa, Ballum, Tarassovi y tampoco en $L$. biflexa serovar Patoc (Figura 2.9B). El transcripto de lic12922 fue encontrado en todas las especies evaluadas (Figura 2.9C). La contaminación con ADN fue descartada a partir de la inexistencia de amplificación observada en ausencia de transcriptasa reversa. La integridad del ARN total usado en la RT-PCR en todas las muestras fue evidenciada mediante la presencia del fragmento de $331 \mathrm{pb}$ que se corresponde con el ADNc de ARNr16S (Figura 2.9D).

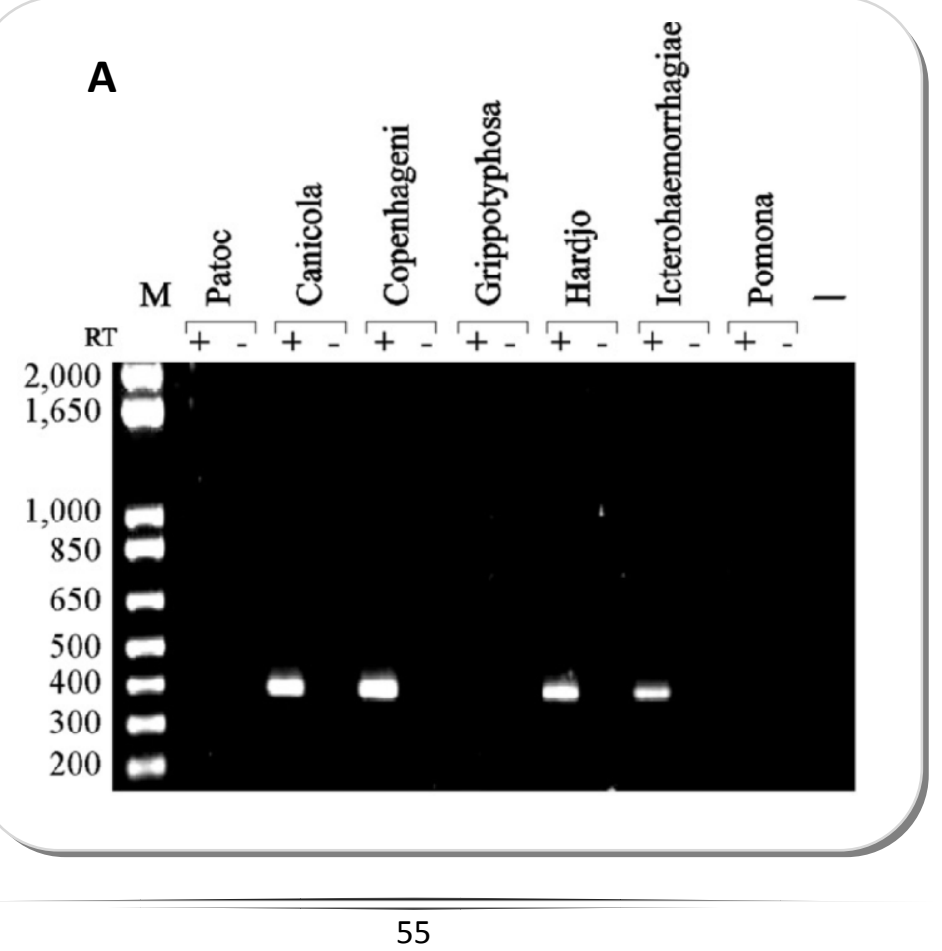




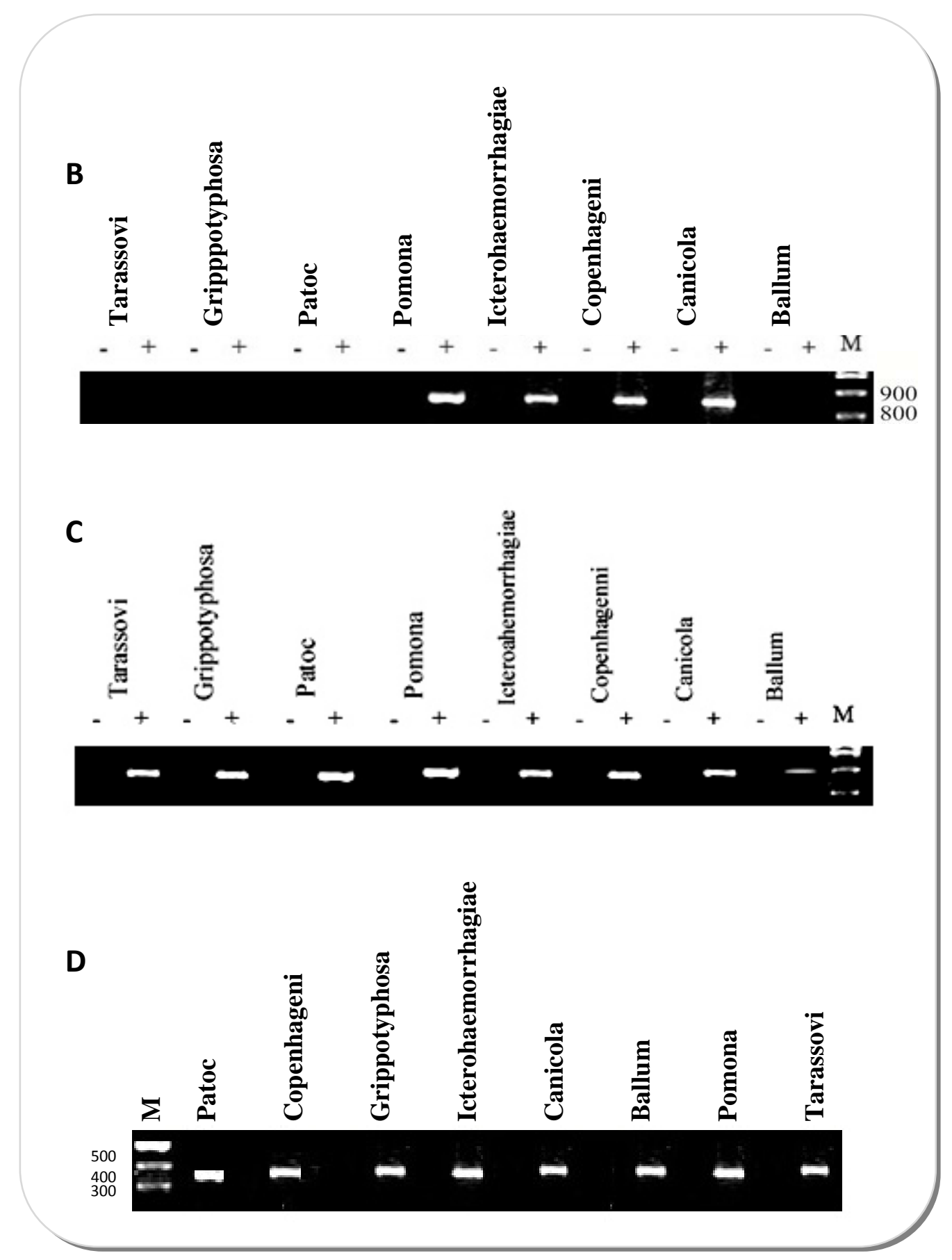

Figura 2.9 Análisis transcripcional de lic12690, lic11207 y lic12922 en especies patogénicas de leptospiras y en la especie saprófita. Se analizó mediante RT-PCR los transcriptos de lic12690 (A), lic11207 (B) y lic12922 (C) en L. biflexa serovar Patoc y en ocho especies patogénicas empleando los mismos pares de primers mencionados en la Figura 2.8. La cantidad e integridad de las muestra fue verificada mediante la amplificación de un fragmento de $331 \mathrm{pb}$, correspondiente al ADNc del gen ARNr16S (D). RT +: transcriptasa reversa presente. RT -: transcriptasa reversa omitida. $\mathbf{M}$ : marcador de peso molecular $(\mathrm{pb})$ 


\subsubsection{Clonado, expresión y purificación de las proteínas recombinantes}

Los genes lic12690, lic11207 y lic12922 fueron amplificados por PCR sin la secuencia del péptido señal, y los productos fueron clonados y expresados como proteínas entera en E. coli. Las proteínas recombinantes, que a partir de ahora Ilamaremos rLp95, rLIC11207 y rLIC12922, respectivamente, fueron expresadas con una cola de 6 histidinas en el extremo $\mathrm{N}$-terminal que permitió su posterior purificación por cromatografía de afinidad metálica utilizando una columna de flujo rápido cargada con $\mathrm{Ni}^{+2}$. Una alícuota de cada etapa del proceso fue analizada por SDS-12\% PAGE. En el caso de rLp95 (Figura 2.10A), la banda esperada de $94.5 \mathrm{KDa}$ se observó en los cultivos de E.coli BL21-SI inducidos con $\mathrm{NaCl}$ y también en los pellets como cuerpos de inclusión (Figura 2.10A calle 3 y 5 , respectivamente). A pesar de que rLp95 presentó un bajo nivel de expresión, se recuperó consistentemente de la columna en ausencia de urea (Figura 2.10A calle 6).

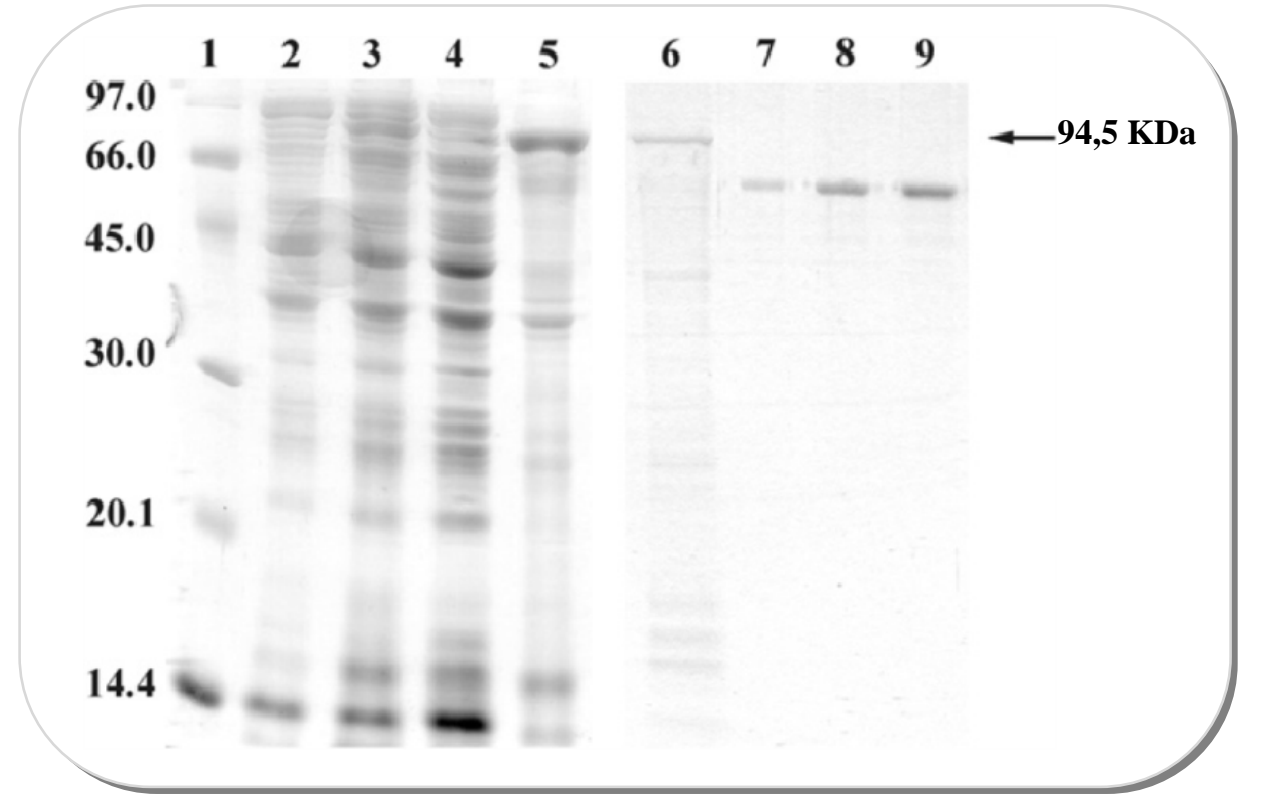

Figura 2.10A Análisis por SDS-12\% PAGE de rLp95 en E. coli BL21-SI inducida con NaCl. 1, marcador de peso molecular (en $\mathrm{KDa}$ ); 2 : cultivo no inducido; $\mathbf{3}$ : cultivo inducido; $\mathbf{4}$ y $\mathbf{5}$ : sobrenadante y cuerpos de inclusión luego de la lisis celular por sonicado/centrifugación, respectivamente; 6: proteína purificada eluída con imidazol $1 \mathrm{M}$ desde columna de sefarosa cargada con $\mathrm{Ni}^{+2} ; \mathbf{7}, 8$ Y 9, BSA $250 \mathrm{ng}, 500 \mathrm{ng}$ y $750 \mathrm{ng}$, usado para estimar la concentración de proteína. Las bandas de proteínas fueron visualizadas con el colorante Coomassie blue. 
La banda esperada de rLIC11207 de 34 KDa pudo observarse en los cultivos de E.coli BL21-SI inducidos con $\mathrm{NaCl}$ y también en los pellets como cuerpos de inclusión (Figura 2.10B, calles 3 y 4, respectivamente). rLIC11207 fue recuperada tras la purificación en condiciones desnaturalizantes (urea 8M) detectándose en las eluciones efectuadas con urea $8 \mathrm{M} \mathrm{pH:} 4$ (Figura 2.10C, calles 5-9). Si bien la banda esperada de 42 kDa correspondiente a rLIC12922 no se observó en los cultivos de E. coli BL21 inducidos con $\mathrm{NaCl}$, si pudo detectarse tras la purificación en condiciones desnaturalizantes (Figura 2.10D).

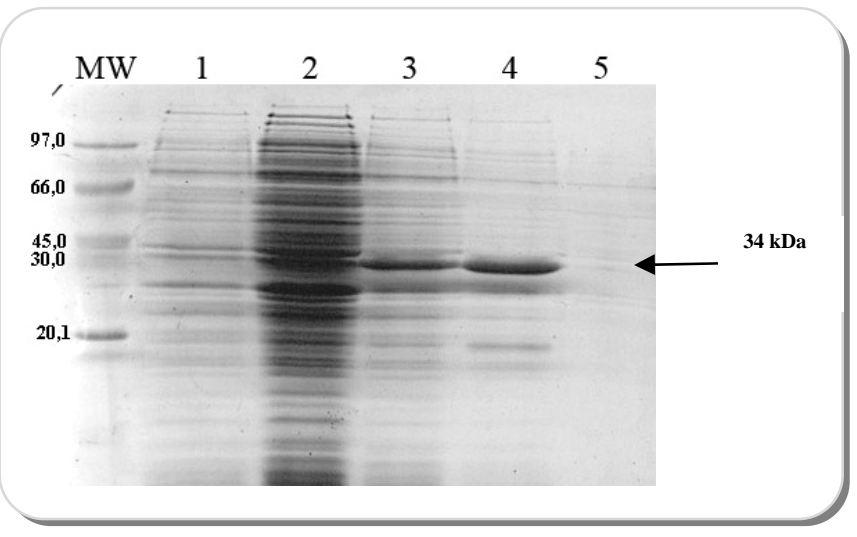

Figura 2.10B Análisis por SDS-12\% PAGE de rLIC11207 en E. coli BL21-SI inducida con $\mathrm{NaCl}$. MW: marcador de peso molecular (en KDa); 1: cultivo sin inducir a tiempo 0 horas 2: cultivo a 3 horas sin inducir; 3 : cultivo inducido; 4 y 5 : cuerpos de inclusión y sobrenadante luego de la lisis celular por sonicado/centrifugación, respectivamente. Las bandas de proteínas fueron visualizadas con el colorante Coomassie blue. Las posiciones correspondientes a los pesos moleculares se ven indicadas a la izquierda (en KDa).

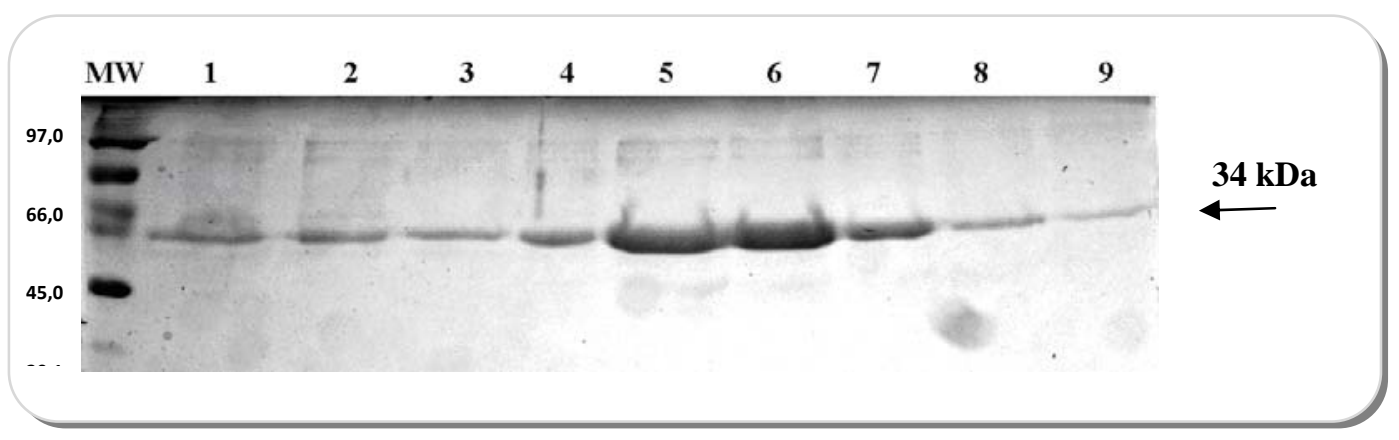

Figura 2.10C Análisis por SDS-12\% PAGE de la purificación de rLIC11207 eluída con urea $8 \mathrm{M}$ desde columna de sefarosa cargada con $\mathrm{Ni}^{+2}$. $\mathbf{M W}$ : marcador de peso molecular (en KDa); calle 1 y 2: primer y segundo lavado con solución de urea $8 \mathrm{M} \mathrm{pH:} 6$ respectivamente; calle 3 y 4: primer y segundo lavado con solución de urea $8 \mathrm{M} \mathrm{pH:} \mathrm{5,3} \mathrm{respectivamente;} \mathrm{calle} \mathrm{5-9:} \mathrm{primer} \mathrm{a}$ quinta elución con solución de urea $8 \mathrm{M} \mathrm{pH}$ : 4.5 fracciones de $1 \mathrm{ml}$ fueron guardadas a -20ㅡ en glicerol $33 \%$ hasta su posterior utilización. 


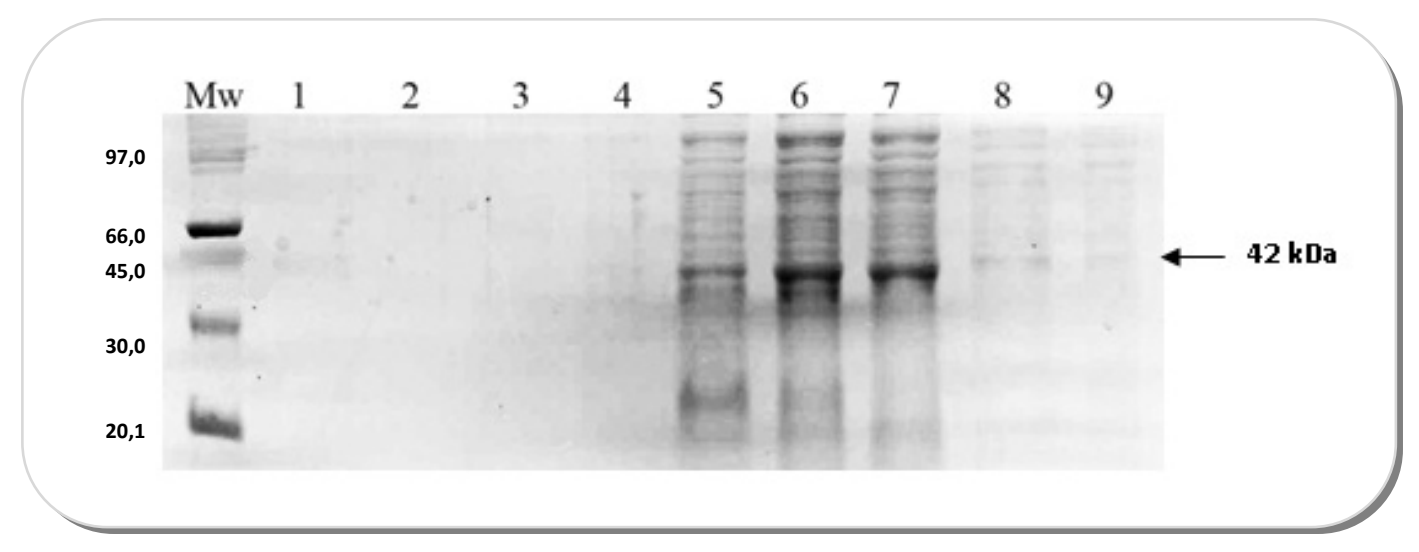

Figura 2.10D Análisis por SDS-12\% PAGE de la purificación de rLIC12922 eluída con urea $8 \mathrm{M}$ desde columna de sefarosa cargada con $\mathbf{N i}^{+2}$. $\mathbf{M W}$ : marcador de peso molecular (en $\mathrm{KDa}$ ); calle 1 y 2: primer y segundo lavado con solución de urea $8 \mathrm{M} \mathrm{pH:} \mathrm{6,} \mathrm{respectivamente;}$

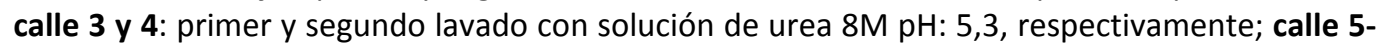
9: primer a quinta elución con solución de urea $8 \mathrm{M} \mathrm{pH:} 4.5$ fracciones de $1 \mathrm{ml}$ fueron guardadas a -20 으 en glicerol $33 \%$.

En los tres casos se realizó el análisis por western blot para confirmar la identidad de la proteína purificada (no se muestra).

rLp95 fue expresada y purificada en condiciones nativas, mientras que rLIC11207 y rLIC12922 lo fueron en condiciones desnaturalizantes. En estos dos últimos casos se aplicó un protocolo de replegado (ver refolding buffer en el capítulo 5).

\subsubsection{Evaluación inmunohistoquímica con sueros anti-rLIC}

Para evaluar si rLp95, rLIC11207 y rLIC12922 son proteínas que se expresan durante la infección, se obtuvieron tejidos de riñón de hámsters infectados a los $14 \mathrm{dpi}$, los cuales se enfrentaron con sueros anti-rLp95, anti-rLIC11207 y antirLIC12922, respectivamente. El uso de anti-rLp95, anti-rLIC11207 y anti-rLIC12922 reveló la presencia de estas proteínas de $L$. interrogans en el lumen tubular renal y en sitios de infiltrado celulares inflamatorios intersticiales (Figura 2.11 A, B y C, 
respectivamente). En el control negativo, el pool de antisueros no mostró reactividad en los cortes de riñones sanos (Figura 2.11D).
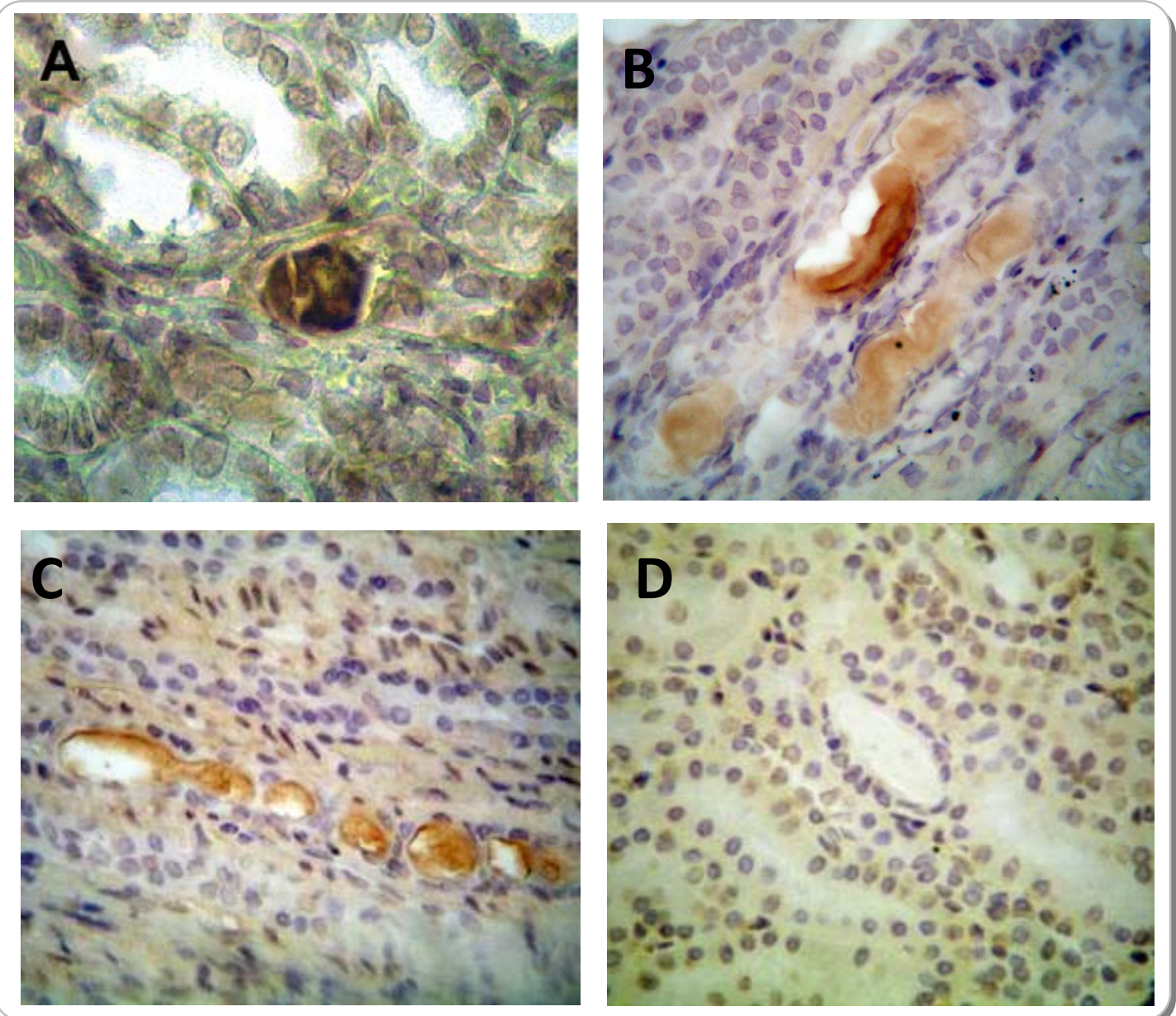

Figura 2.11 Inmunohistoquímica. Tejidos de riñón de hámsters obtenidos 14 días después de la infección con L. interrogans serovar Copenhageni Fiocruz L1-130 que fueron tratados con suero anti-rLp95, anti-rLIc11207 y anti-rLIC12922. (A, B y C). Reconocimiento de Lp95, LIC11207 y LIC12922 dentro del lumen tubular renal, respectivamente. (D) No se observó reactividad cuando los sueros se emplearon en riñones de animales no infectados. Los preparados fueron contracoloreados con hematoxilina. Aumento empleado 350X en B, C y D y $400 \mathrm{X}$ en A . 


\subsubsection{Reactividad de las proteínas recombinantes con sueros de pacientes infectados}

A fin de conocer si las proteínas obtenidas rLp95, rLIC11207, rLIC12922 eran reconocidas por anticuerpos presentes en los sueros de pacientes infectados, se realizaron ensayos de ELISA. En cada ensayo se incubó una de las proteínas recombinantes tanto con sueros de pacientes sanos cómo con los de pacientes convalecientes. Como control positivo se utilizaron los antisueros generados antirLp95, anti-rLIC11207 y anti-rLIC12922, respectivamente y como control negativo de antígeno se utilizó este mismo antisuero y BSA como sustrato en lugar de la proteína recombinante. Los resultados expuestos en las Figuras 2.12, 2.13 y 2.14 indican que ambos tipos de sueros reconocen a rLp95, rLIC11207 y a rLIC12922, pero el título de anticuerpos específicos es significativamente mayor en los pacientes enfermos para rLp95 y rLIC11207, definiendo título a la inversa de la dilución interpolada a la que se alcanza el valor de absorbancia correspondiente a la mitad de la absorbancia máxima. En contraste, no se observaron diferencias significativas en el título de anticuerpos específicos contra rLIC12922 entre pacientes sanos y enfermos. 

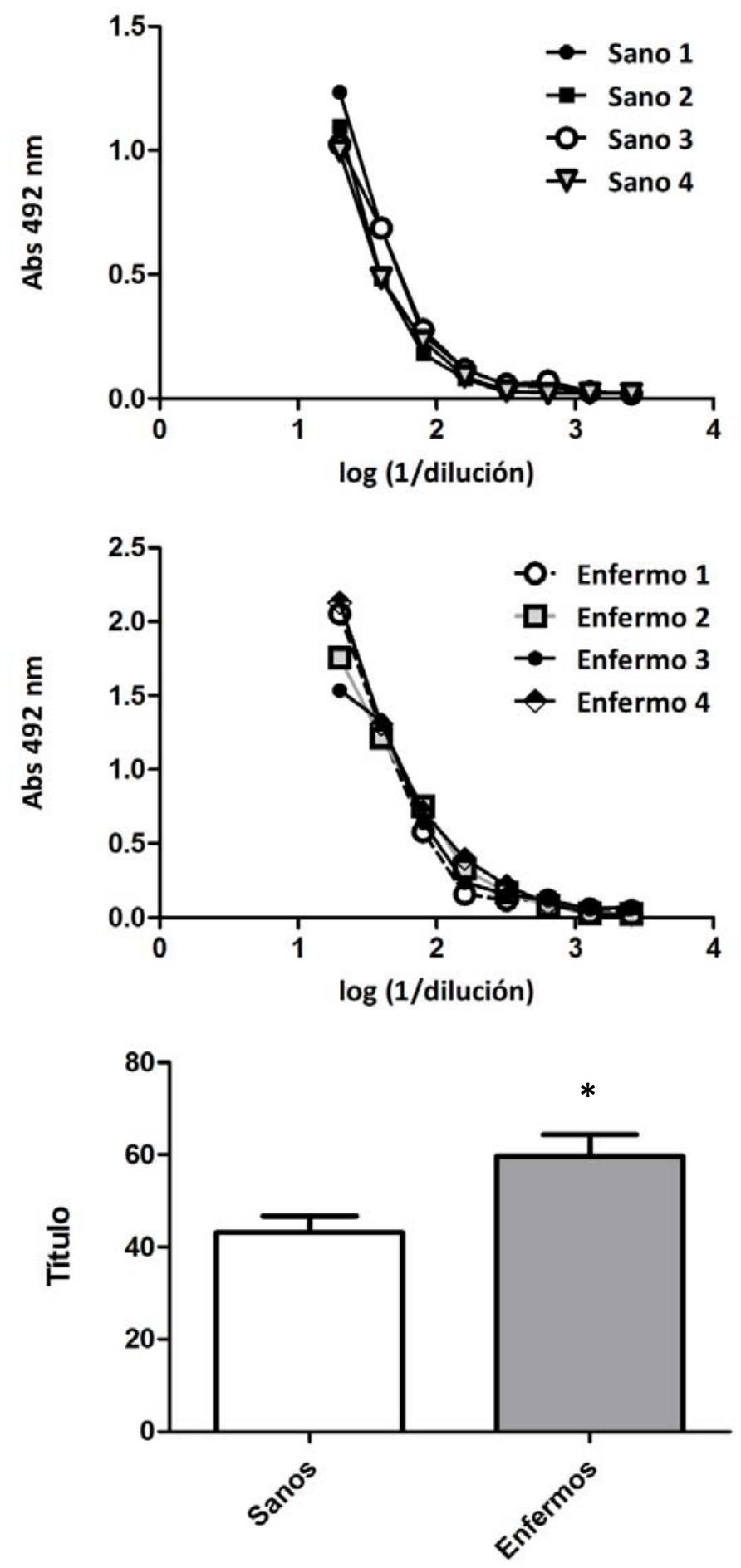

Figura 2.12 Reactividad de rLp95 con suero de pacientes infectados. Una placa de ELISA fue incubada ON con rLp95. A y B: Reactividad de rLp95 con diluciones seriadas de pacientes sanos y enfermos respectivamente. C: Se representa la media del título de anticuerpos definido como la inversa de la dilución correspondiente a la mitad de la absorbancia máxima $\pm \mathrm{DE}$. El * indica un valor de $p<0,05$. 

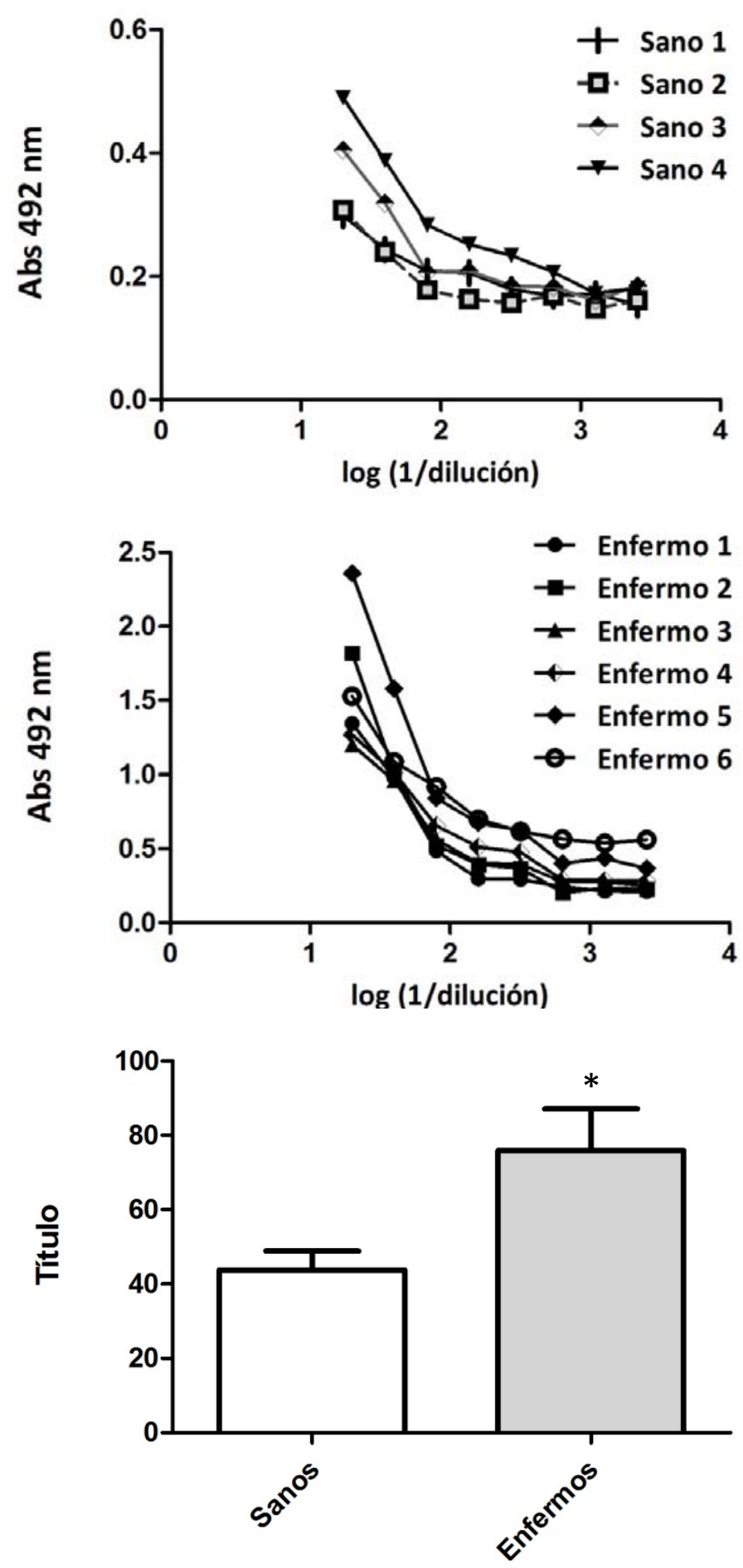

Figura 2.13 Reactividad de rLIC11207 con suero de pacientes infectados. Una placa de ELISA fue incubada ON con rLIC11207. A y B: Reactividad de rLIC11207 con diluciones seriadas de pacientes sanos y enfermos, respectivamente. C: Se representa la media del título de anticuerpos definido como la inversa de la dilución correspondiente a la mitad de la absorbancia máxima $\pm \mathrm{DE}$. El * indica un valor de $\mathrm{p}<0,05$. 

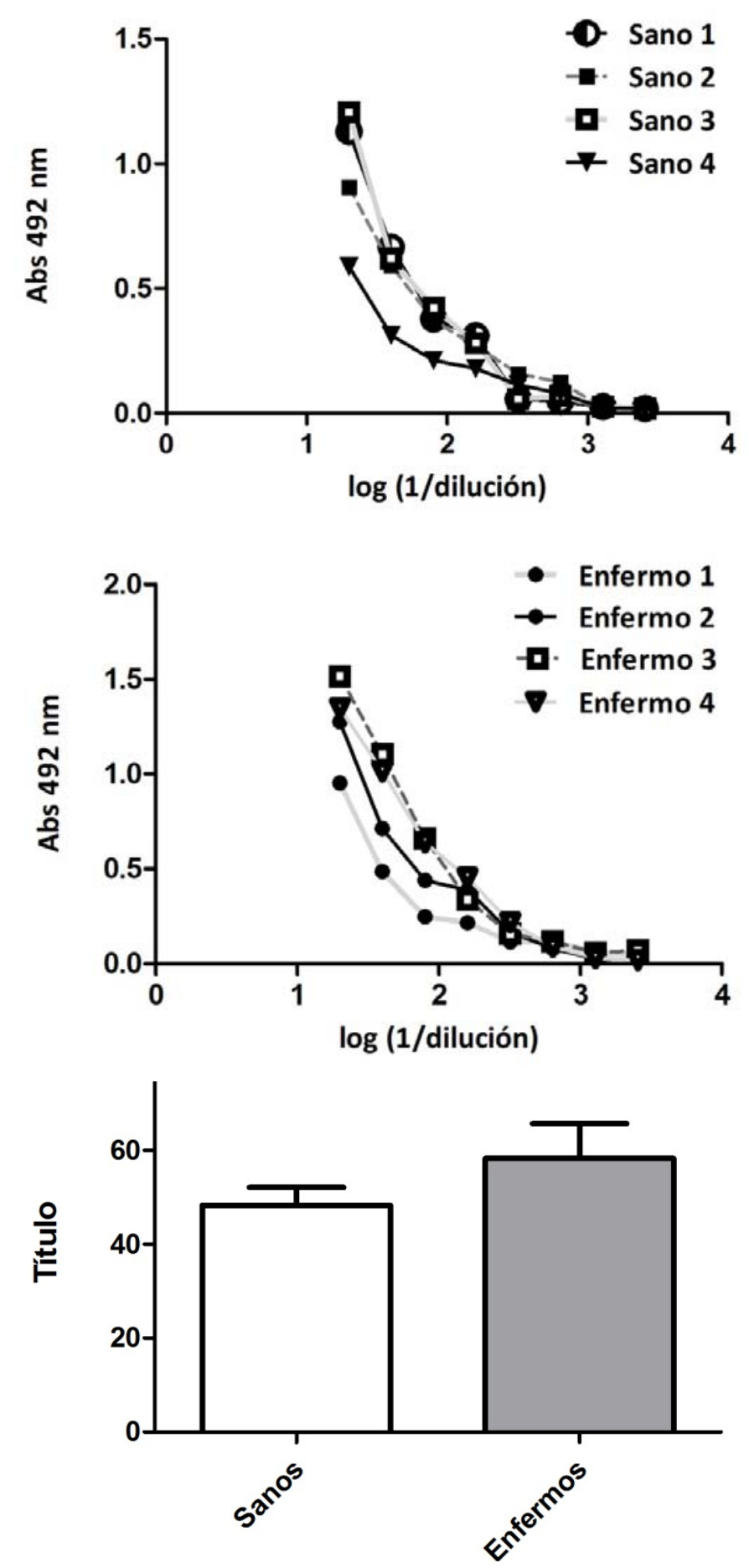

Figura 2.14 Reactividad de rLIC12922 con suero de pacientes infectados. Una placa de ELISA fue incubada ON con rLIC12922 A y B: Reactividad de rLIC12922 con diluciones seriadas de pacientes sanos y enfermos respectivamente. C: Se representa la media del título de anticuerpos definido como la inversa de la dilución correspondiente a la mitad de la absorbancia máxima \pm DE. No se observan diferencias significativas en el título de anticuerpos de los sueros evaluados. 
Los resultados obtenidos en los tres ensayos de ELISA fueron comprobados por inmunoblotting, demostrando el reconocimiento de rLp95 y rLIC11207 solo por los sueros de los pacientes convalecientes, mientras que rLIC12922 es reconocida de igual modo por ambos tipos de sueros. Luego de correr las proteínas obtenidas en un gel de $12 \%$ de poliacrilamida, se transfirieron a la membrana y cada una de ellas fue expuesta tanto a un pool de pacientes sanos y a otro de enfermos. Los resultados obtenidos se muestran en la Figura 2.15

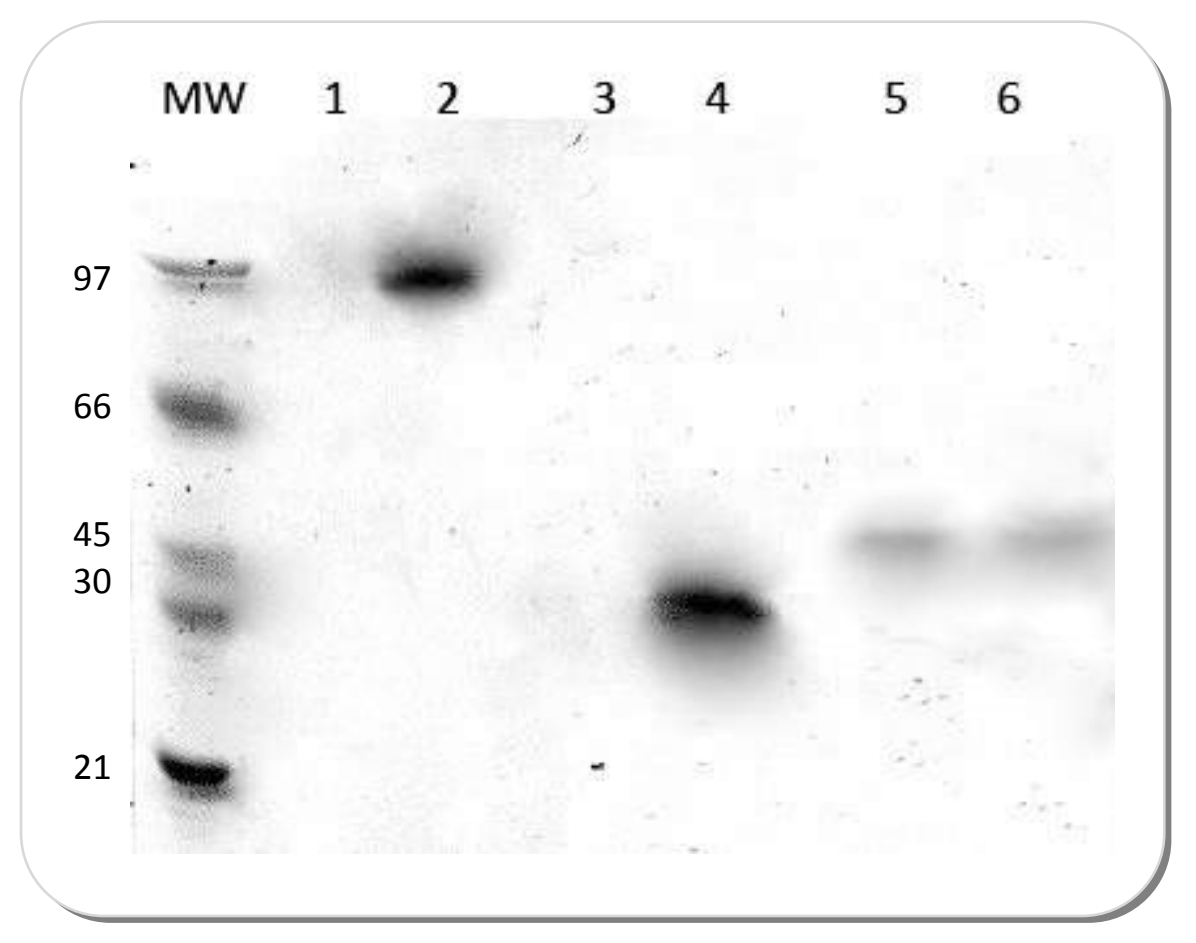

Figura 2.15 Inmunobloting. Calle 1 y 2: reactividad de rLp95 con un pool de pacientes sanos y enfermos, respectivamente. Calle 3 y 4: reactividad de rLIC11207 con un pool de pacientes sanos y enfermos, respectivamente. Calle 5 y 6: reactividad de rLIC12922 con un pool de pacientes sanos y enfermos, respectivamente. 


\subsubsection{Activación endotelial}

El endotelio está involucrado en numerosos procesos fisiológicos, que tienen como objetivo principal el de mantener la fluidez de la sangre. En condiciones normales, las células endoteliales en reposo presentan un fenotipo anticoagulante, antiadhesivo y vasodilatador. Sin embargo una vez activadas, las mismas presentan actividad procoagulante, proadhesiva y vasoconstrictora. El endotelio juega un rol fundamental en la cascada inflamatoria mediada por citoquinas ya que no solo las sintetiza y las libera al medio extracelular sino que además expresa receptores para numerosos de estos mediadores celulares. La activación endotelial puede ser inducida por un amplio rango de agentes y estímulos, como por ejemplo, ciertas bacterias, virus y citoquinas tales como interleuquina-1 (IL-1) y factor de necrosis tumoral (TNF $\alpha$ ), estrés físico y oxidativo, lipoproteínas de baja densidad oxidadas, complejos inmunes, y activación de linfocitos B y T. Hoy se considera que muchas patologías de diversos orígenes coinciden en una activación endotelial descontrolada. Esta tendría un rol patofisiológico central en varias condiciones incluyendo diabetes, ateroesclerosis, síndrome de respuesta inflamatoria sistémica (SRIS), daño isquémico/reperfusión, rechazo de transplante, y vasculitis, síntoma principal de la leptospirosis. Las cinco manifestaciones principales de la activación endotelial son: pérdida de la integridad vascular, expresión de moléculas de adhesión leucocitarias, cambio del fenotipo antitrombótico a protrombótico, producción de citoquinas y una sobreexpresión de moléculas del sistema de histocompatibilidad. Se reconocen dos tipos de respuestas de activación endotelial denominadas tipo I y tipo II respectivamente. La primera no requiere síntesis de proteínas de novo, ocurre en segundos y está mediada por la liberación del contenido de moléculas proadhesivas y proinflamatorias depositadas en los cuerpos de Weibel Palade de la célula endotelial incluyendo la P-selectina y el Factor von Willebrand (vWF). La segunda requiere la transcripción de genes y la síntesis de proteínas por lo tanto ocurre algunas horas después del estímulo. Entre las proteínas que están 
reguladas por este tipo de respuesta se encuentra la expresión de E-selectina, ICAM-1 (intercellular cell adhesion molecule-1) y VCAM-1 (vascular cell adhesion molecule-1) y moléculas proinflamatorias como IL-6 e iNOS (inducible nitric oxide synthase). Estos efectos comparten un mecanismo de control intracelular común a través de la activación del factor de transcripción nuclear NF-к $\beta$.

\section{a) Cultivo de HUVEC (human umbilical vein endothelial cells)}

Los estudios de activación endotelial se realizaron utilizando células endoteliales humanas de la vena umbilical o HUVEC. Las mismas fueron obtenidas según se describió previamente (Gómez, 2008). Brevemente, se limpió el cordón con alcohol y se cortaron los extremos con tijera estéril, se canuló la vena umbilical con una llave de tres vías y se clampeó el mismo extremo para asegurar que la llave quedase fija. Se inyectó una solución de colagenasa tipo IV 0,1\% y se incubó en estufa a $37^{\circ} \mathrm{C}$ por 15 minutos. Luego se liberó el extremo sin cánula, se recogió la suspensión celular en un tubo estéril y nuevamente se realizó un lavado con solución fisiológica para extraer las células remanentes. Luego de la centrifugación el pellet de células endoteliales se resuspendió en el medio de crecimiento RPMI 1640 y se transfirió a un frasco de cultivo previamente gelatinizado el cual se mantuvo en estufa a $37^{\circ} \mathrm{C}$ en una atmósfera con $5 \%$ de $\mathrm{CO}_{2}$ hasta que las células formaran una monocapa (Figura 2.16). Las células fueron inicialmente identificadas por morfología. Como se observa en la Figura 2.16A, las células endoteliales se diferencian de los fibroblastos en que son más pequeñas, con estructura más romboidal, mientras que los fibroblastos son mas alargados y grandes (Figura 2.16B). La confirmación de la identidad fue realizada por marcación con un anticuerpo anti Factor von Willebrand (VWF) (Immunotech, France) por citometría de flujo. La pureza fue del $90 \%$. Una vez alcanzada la confluencia, las células fueron despegadas con un tratamiento suave de tripsinaEDTA (0.05\% y $0.1 \mathrm{mM}$, respectivamente), lavadas con PBS ( $\sin \mathrm{Ca}^{2+}$ y $\mathrm{Mg}^{2+}$ ) 
suplementado con $10 \%$ de FBS y finalmente sembradas en placas de 96 wells. Las HUVEC fueron usadas entre los pasajes 1-3.

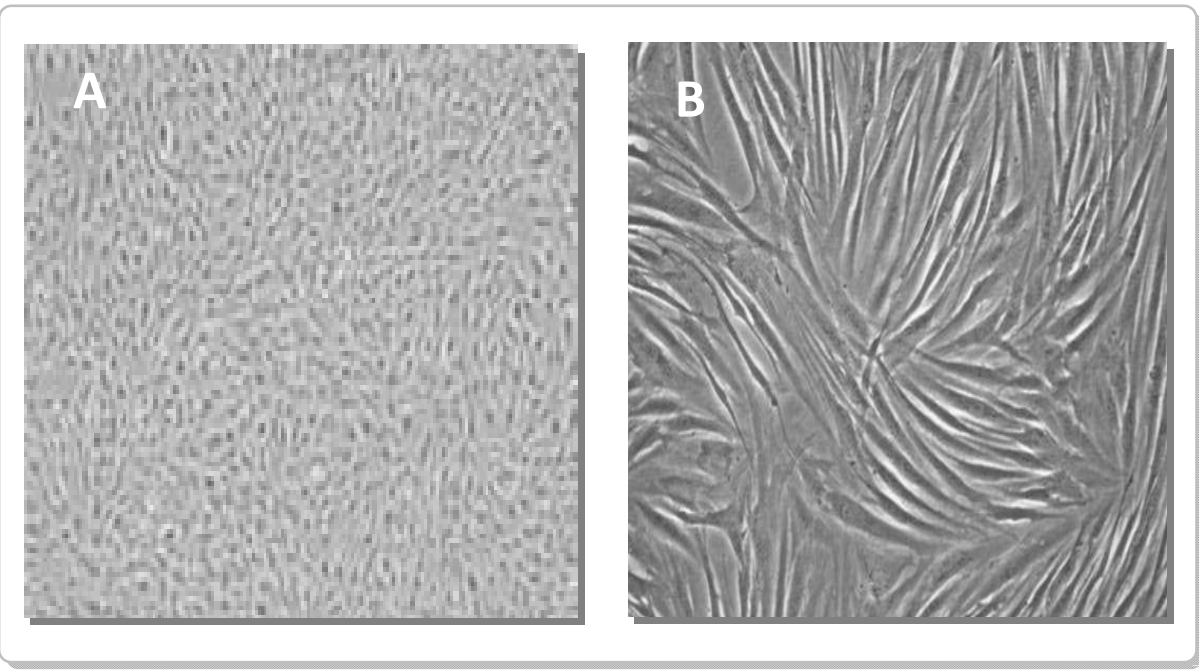

Figura 2.16 Cultivo de células endoteliales de cordón umbilical. A Observación de monocapa de HUVEC donde se aprecian células pequeñas y romboidales. B Observación de fibroblastos, células de mayor tamaño y aspecto alargado. Aumento 100X.

\section{b) Presencia de LPS en las proteínas recombinantes}

Las proteínas recombinantes expresadas en $E$. coli generalmente están contaminadas con LPS. EI LPS es capaz de activar las HUVEC y también de inducir inhibición de la apoptosis de los polimorfonucleares. Por esta razón antes de realizar los ensayos fue necesario conocer la contaminación por LPS presente en cada muestra. Los niveles de LPS se determinaron utilizando un LAL-test (del inglés, Limulus amebocyte lysate assay). Los resultados obtenidos se muestran en la tabla 2.5 . 
Tabla 2.5. Cantidad de LPS en cada muestra, obtenida mediante ELISA

\begin{tabular}{ccc}
\hline Proteína & LPS $(\mu \mathrm{g} / \mathrm{ml})$ & $\begin{array}{c}\mu \mathrm{g} \text { de LPS } / \mu \mathrm{g} \text { de proteína } \\
\text { recombinante }\end{array}$ \\
\hline rLp95 & $1.4 \times 10^{-3}$ & $1.1 \times 10^{-4}$ \\
rLIC11207 & $1 \times 10^{-4}$ & $8 \times 10^{-6}$ \\
rLIC12922 & 1470 & 117.6 \\
rLIC12906 & 294 & 82 \\
\hline
\end{tabular}

\section{c) Expresión endotelial de E-selectina e ICAM-1}

Para evaluar si las células endoteliales son activadas por la presencia de rLp95, rLIC11207 y rLIC12922 se trataron cultivos de HUVEC con $25 \mu \mathrm{g}$ de cada proteína recombinante y luego de 4 o 16 horas se analizaron por citometría de flujo los niveles superficiales de E-selectina e ICAM-1, respectivamente, usando anticuerpos monoclonales conjugados a FITC. Los resultados mostraron que la expresión de E-selectina fue notoriamente mayor luego del tratamiento con rLp95 pero no luego del tratamiento con rLIC11207 (Figura 2.17A). Tanto rLp95 como rLIC11207 no aumentaron la expresión de ICAM-1 (Figura 2.17B). Aunque el contenido estimado de LPS en la muestra de rLp95 fue $1.1 \times 10^{-4} \mu \mathrm{g}$ por $\mu \mathrm{g}$ de Lp95 se descartó que el aumento en la expresión de E-selectina sea debida al LPS realizando el ensayo en presencia de polimixina $B(P M B)$, antibiótico que neutraliza al LPS mediante la unión al lípido $A$, componente principal de la endotoxina. La PMB en la concentración utilizada $(7 \mu \mathrm{g} / \mathrm{ml}$, máxima concentración que no ejerce efectos citotóxicos) es capaz de secuestrar cantidades de LPS de hasta $1 \mu \mathrm{g} / \mathrm{ml}$. Además, el tratamiento de las HUVEC con la proteína recombinante rLIC12906 que expresaba niveles más altos de LPS que la rLp95 $\left(1.1 \times 10^{-4} \mu \mathrm{g}\right.$ de LPS/ $\mu \mathrm{g}$ de rLp95) no fue capaz de aumentar la expresión de Eselectina e ICAM-1 (Figura 2.17, barras de color negro). Sin embargo la expresión aumentada de E-selectina e ICAM-1 debida a rLIC12922 muy probablemente esté asociada al LPS residual el cual debido a su alta concentración $(1470 \mu \mathrm{g} / \mathrm{ml})$, no 
llega a ser totalmente inhibido por la presencia de PMB.
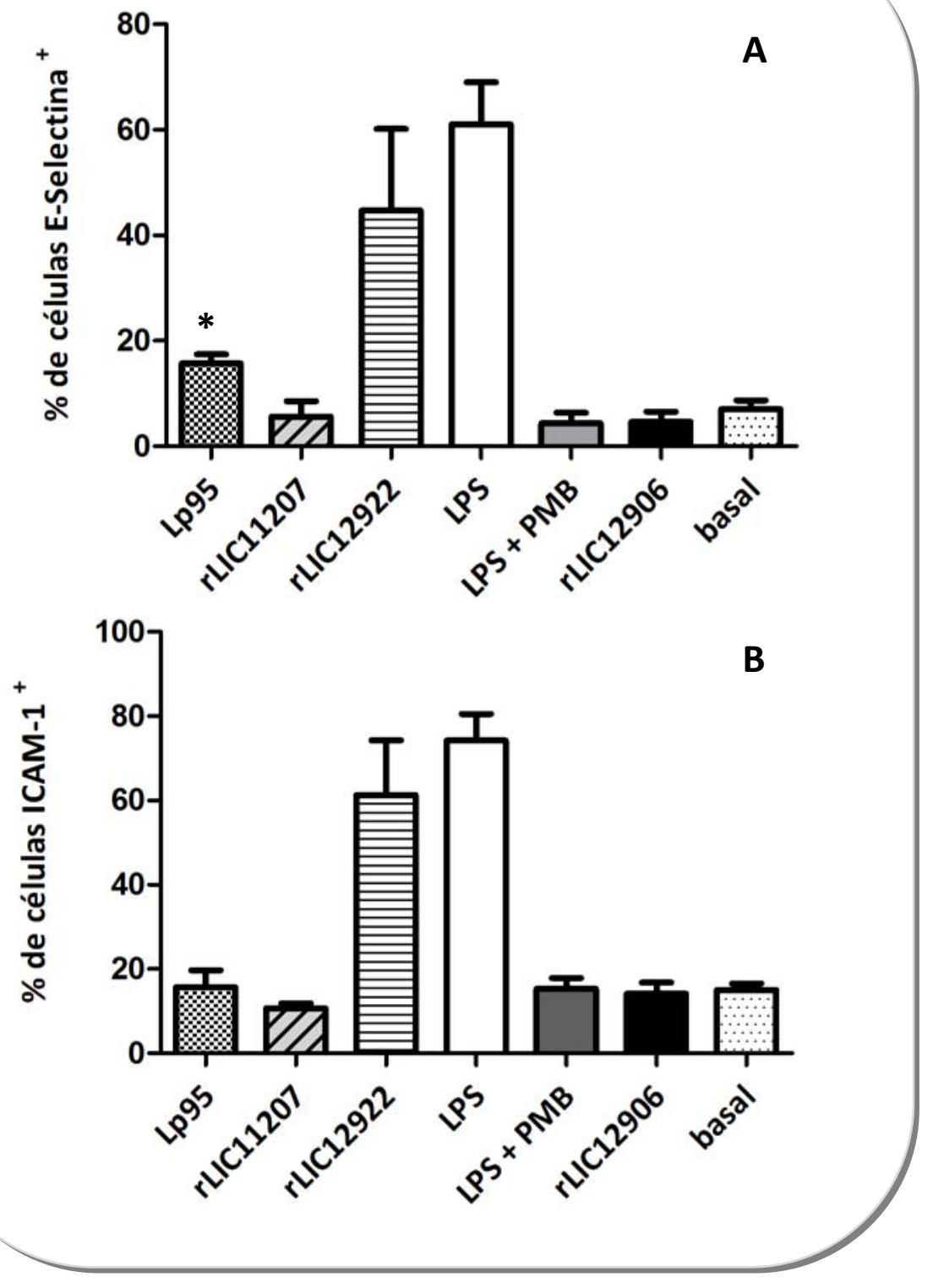

Figura 2.17 Inducción de la expresión de E-selectina e ICAM-1 en HUVECs por rLp95, rLIC11207 y rLIC12922. Monocapas confluentes de HUVEC tratadas con PMB $(7 \mu \mathrm{g} / \mathrm{ml})$ fueron tratadas durante 1 hora con $25 \mu \mathrm{g} / \mathrm{ml}$ de proteína recombinante. Luego el medio fue removido y las células se cultivaron más de 4 horas en RPMI-1640 suplementado con FBS al 10\%. Como control negativo se realizó la incubación con rLIC12906 $(50 \mathrm{mg} / \mathrm{ml}$ ) (barra negra). Como control positivo se usó LPS $(1 \mu \mathrm{g} / \mathrm{ml})$ con y sin el agregado de PMB $(7 \mu \mathrm{g} / \mathrm{ml}$ ) (barra y gris y blanca, respectivamente). A y B muestran el porcentaje de células E-selectina ${ }^{+}$y de células ICAM- $1^{+}$, respectivamente. Los datos mostrados son la media \pm SEM de tres experimentos independientes. ${ }^{*} p<0,01$ vs basal. 
Para determinar con mayor precisión si la activación endotelial era inducida únicamente por las proteínas recombinantes y no por el LPS contaminante se trataron las mismas con proteinasa $\mathrm{K}(\mathrm{PK}, 500 \mathrm{ng} / \mathrm{ml})$, enzima que degrada proteínas. El tratamiento con PK se llevó a cabo también con TNF- $\alpha$ (10 ng/ml), incluido en el experimento como control positivo y susceptible a la acción de la PK y con LPS $(1 \mu \mathrm{g} / \mathrm{ml})$, el cual induce la expresión de ICAM-1 y de Eselectina y no se ve afectado por el agregado de PK. La inducción de las CAMs fue medida antes y después del tratamiento con la enzima.

Puede observarse que tanto el tratamiento de $\operatorname{rlp} 95(25 \mu \mathrm{g} / \mathrm{ml})$ como de TNF$\alpha$ con PK, suprimió completamente la inducción de E-selectina (Figura 2.18A y 2.18B). Como se esperaba, la sobreexpresión de E-selectina promovida por LPS no fue modificada por la presencia de PK (Figura 2.18C).
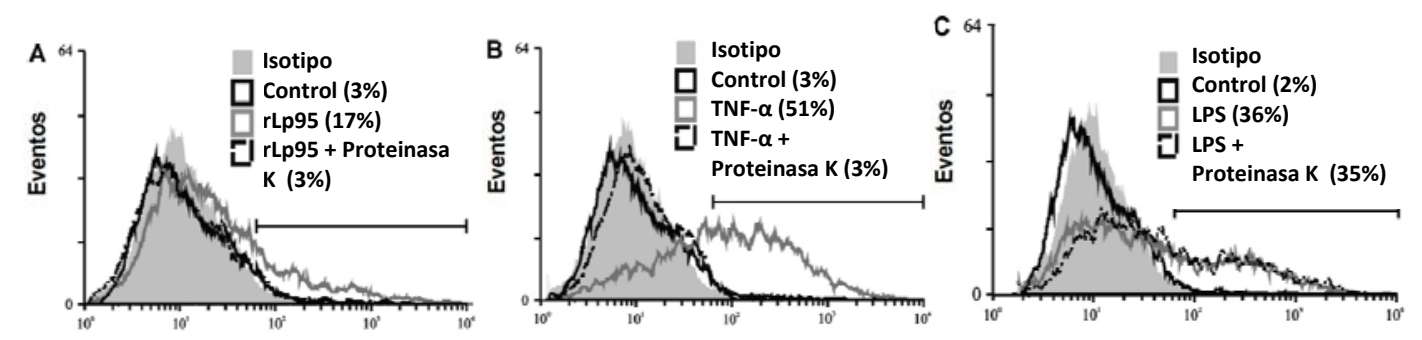

Figura 2.18 Efecto de PK sobre la inducción de la expresión de E-selectina en HUVEC por Lp95. Los histogramas de citometría de flujo muestran los efectos del tratamiento de $\mathrm{rLp95}(25 \mu \mathrm{g} / \mathrm{ml})$ (A), TNF- $\alpha(10 \mathrm{ng} / \mathrm{ml})$ (B) y LPS $(1 \mathrm{mg} / \mathrm{ml})$ (C) con proteinasa $\mathrm{K}(500 \mathrm{ng} / \mathrm{ml})$ previo a la inducción de Eselectina.

d) Comparación de la expresión endotelial de E-selectina e ICAM-1 promovida por Leptospira interrogans y Leptospira biflexa.

Si bien la inducción de moléculas de CAM en HUVEC por varias proteínas recombinantes de leptospira ha sido evaluada anteriormente (Vieira, 2007; 
Gómez, 2008), el efecto directo por Leptospira spp. aun no se conoce. La Figura 2.19 muestra que tanto la patógena $L$. interrogans como la saprófita L. biflexa indujeron la expresión de ICAM-1 y de E-selectina. Sin embargo el aumento inducido por $L$. interrogans fue significativamente mayor que el de L. biflexa.

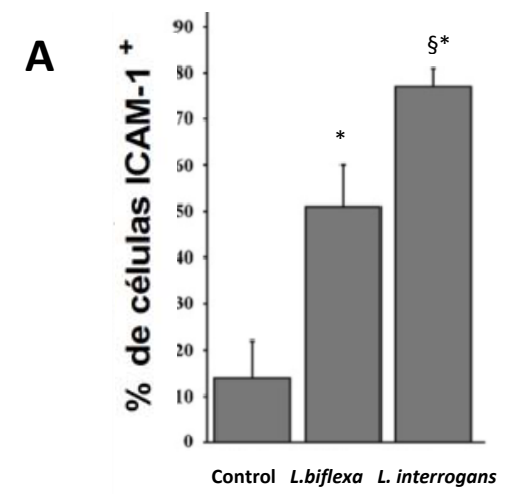

B

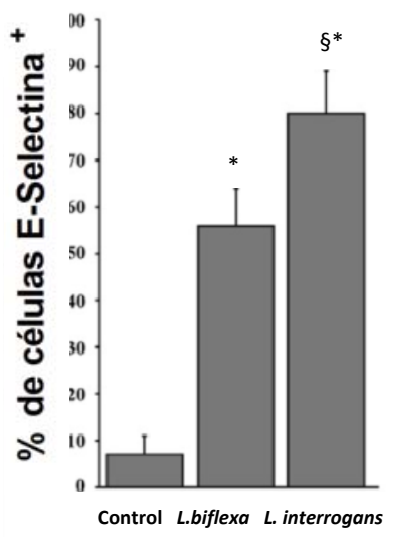

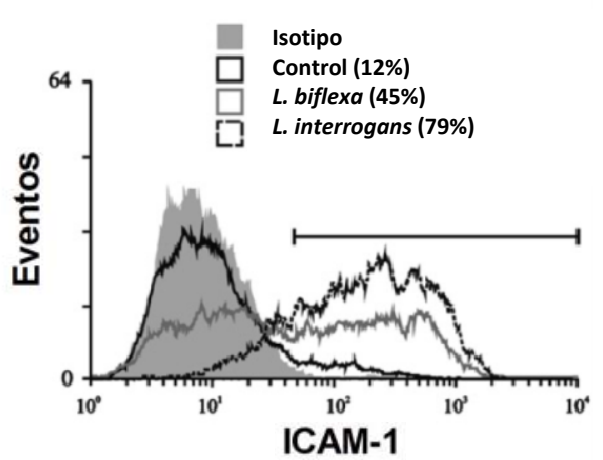

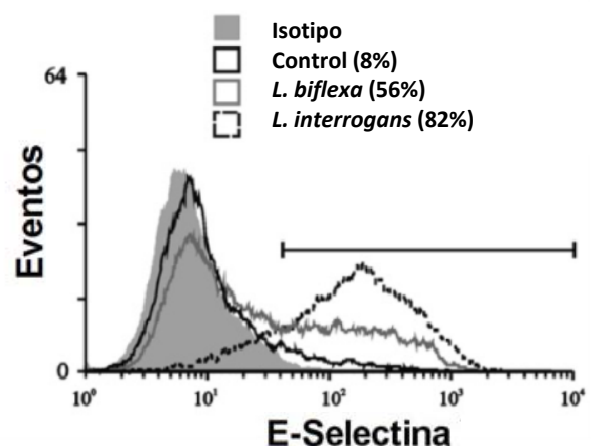

Figura 2.19 Inducción de la expresión de CAMs por cepas de Leptospira spp. A y B inducción de ICAM-1 y E-selectina por L. biflexa serovar Patoc y por L. interrogans serovar Copenhageni. * $p<0,01$ vs control y $* \S p<0,01$ vs leptospiras no patogénicas. Los paneles de la derecha muestran los histogramas de citometría de flujo para ambos experimentos. Los datos mostrados son la media $\pm \mathrm{DE}$ de tres experimentos independientes.

\section{e) Liberación de Factor de von Willebrand}

El vWF es una glicoproteína que se sintetiza y almacena en las células endoteliales (cuerpos de Weibel-Palade), megacariocitos y plaquetas (gránulos alfa). Asimismo, presenta un importante papel favoreciendo la adhesión de las 
plaquetas a la matriz subendotelial y la agregación plaquetaria (actuando como nexo de unión entre las glicoproteínas lb (vía clásica) o llb-Illa (vía alternativa) expresadas en su superficie. Se ha propuesto el incremento de liberación del mismo como indicador de daño endotelial y este proceso es dependiente del $\mathrm{Ca}^{+2}$.

Para saber si rLp95, rLIC11207 y rLIC12922 son capaces de inducir la liberación de VWF se expusieron HUVEC durante 1 hora con $25 \mu \mathrm{g}$ de proteína recombinante. Luego, las células HUVEC fueron tripsinadas, centrifugadas y la cantidad de VWF fue determinada en el sobrenadante por ELISA. Los resultados se expresan en $\mathrm{ng} / \mathrm{ml}$ y fueron extrapolados de una curva estándar realizada con diluciones seriadas de un pool de plasma normal asumiendo que la concentración de vWF en el mismo es de $10 \mu \mathrm{g} / \mathrm{ml}$. Como control positivo se realizó la incubación de HUVEC con trombina, la cual induce la liberación de vWF. Como puede observarse en la Figura $\mathbf{2 . 2 0}$ ninguna de las tres proteínas utilizadas en este ensayo fueron capaces de producir la liberación del vWF.

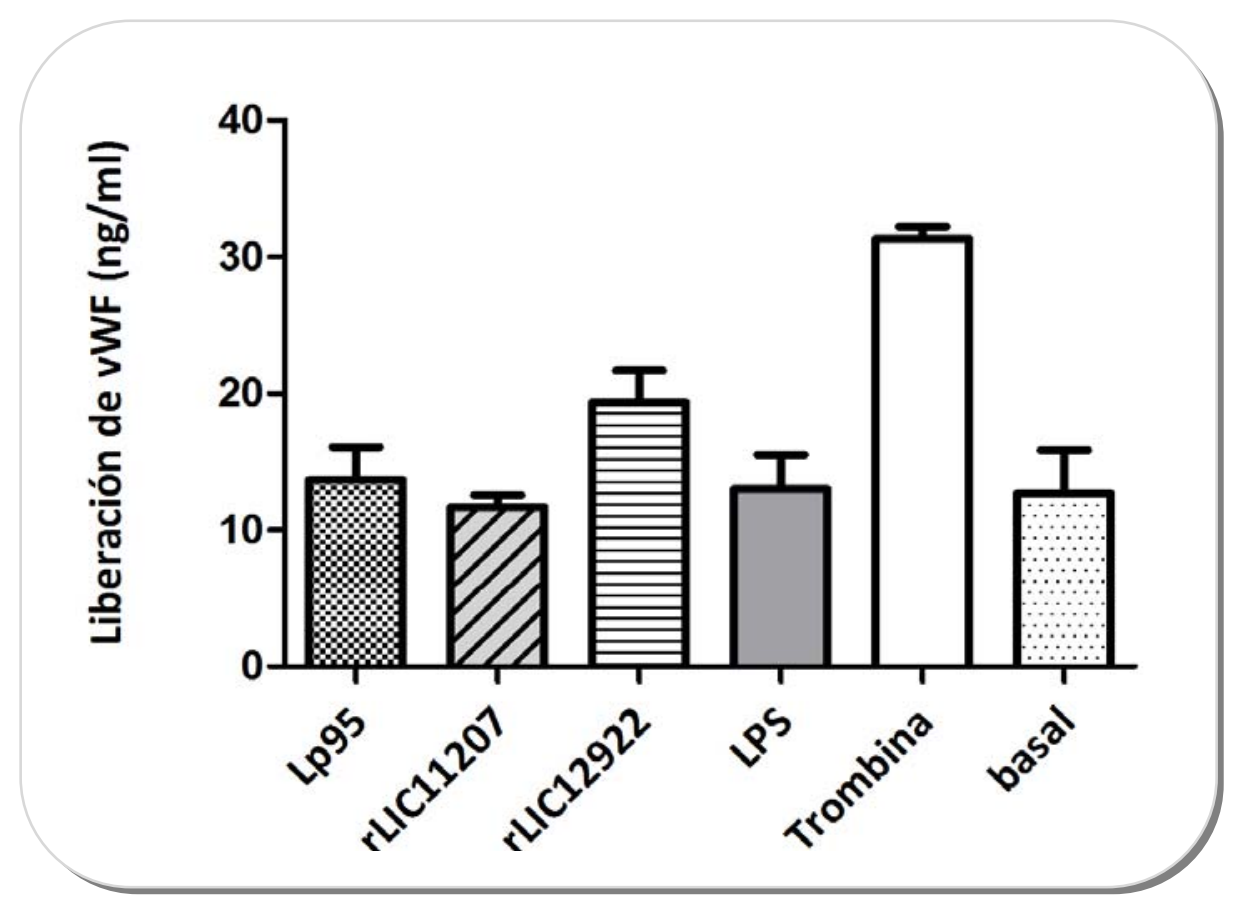

Figura 2.20 Liberación de Factor de von Willebrand en el sobrenadante de HUVEC que fueron expuestas durante 1 hora a $25 \mu \mathrm{g}$ de proteína recombinante estimada por ELISA. Puede observarse la ausencia de diferencias significativas entre los valores observados y el control. 


\subsubsection{Inhibición de la apoptosis}

La apoptosis o muerte celular programada es un proceso normal en el desarrollo por el cual células débiles, dañadas, o innecesarias en un organismo mueren de manera controlada y regulada. Sin embargo, cuando por algún motivo este programa se encuentra desregulado, las células o tejidos sufren una apoptosis insuficiente o excesiva que está implicada en la patogenia de varias enfermedades. Dentro de la célula existen señales de sobrevida y señales de muerte que están perfectamente balanceadas para mantener la homeostasis celular. Cuando este balance se ve alterado y los mecanismos de muerte predominan, se desencadena el proceso apoptótico

\section{Tinción de Naranja de Acridina /Bromuro de Etidio}

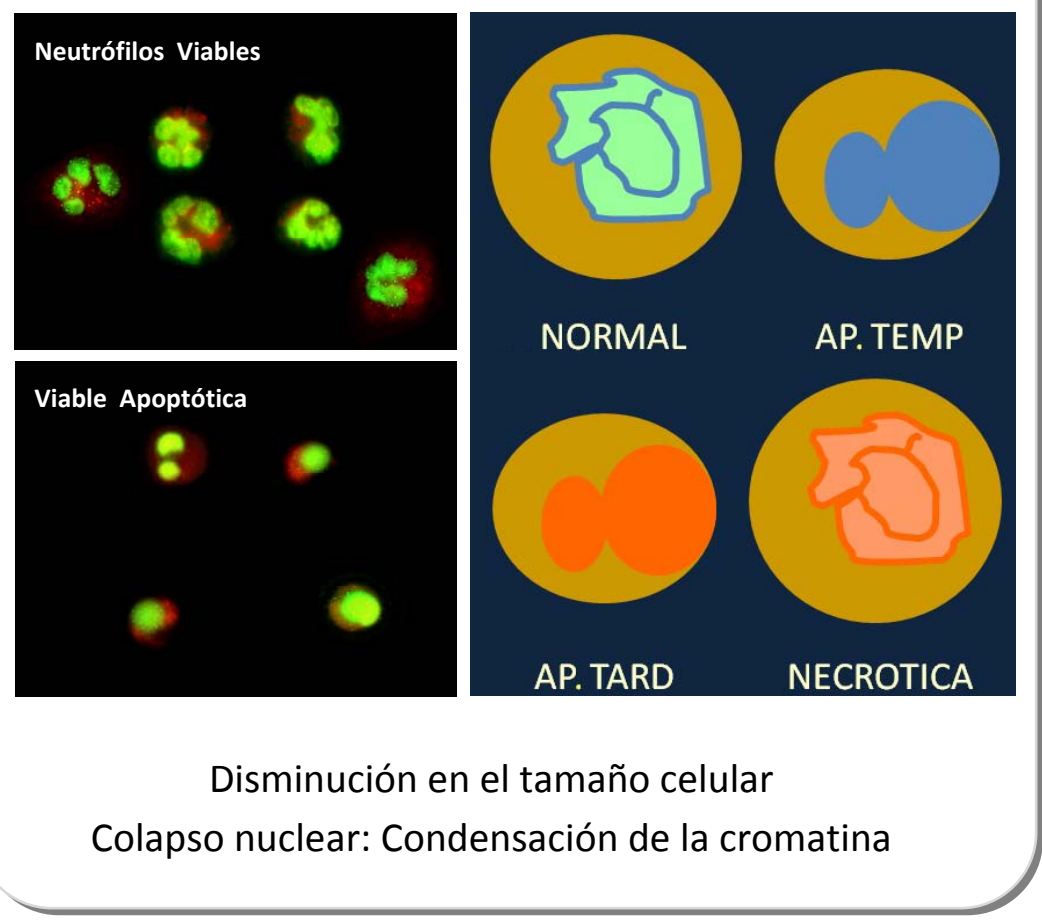

Figura 2.21 Tinción con naranja de acridina (NA) y bromuro de etidio (BrEt) frente a la luz UV. El NA, que emite fluorescencia verde tiene la capacidad de atravesar la membrana plasmática de las células y unirse al ADN. El BrEt, que emite fluorescencia naranja es excluido de las células viables que conservan la integridad de la membrana plasmática. Cuando las células son normales o apoptóticas tempranas su membrana se encuentra intacta, permitiendo sólo el paso del NA y se ven verdes. Sin embargo, entre ellas se diferencian por los pequeños núcleos con la cromatina condensada típicos de células apoptóticas. Cuando las células son apoptóticas tardías o necróticas son permeables a los dos colorantes y en estas condiciones, la fluorescencia del BrEt supera a la de NA y los núcleos se ven naranjas. Nuevamente nos remitimos a la condensación nuclear para diferenciarlas ya que solamente las células apoptóticas tardías presentan núcleos picnóticos. 
Los patógenos bacterianos han desarrollado diversas estrategias para modificar las funciones de la célula huésped en su beneficio. Por ejemplo, la inducción de la apoptosis inducida por un patógeno puede servir para eliminar las células inmunes claves o para evadir los otros sistemas de defensa del huésped (Weinrauch and Zychlinsky, 1999). En particular, las bacterias intracelulares han adaptado sus mecanismos de infección para modular la vía de apoptosis de las células de su huésped. La inducción resultante o la inhibición de la apoptosis son a menudo cruciales para el éxito de la infección. Varias bacterias provocan un proceso inflamatorio mediante la inducción de la muerte celular por apoptosis, que en el lugar de la infección conduce a la ruptura de barreras de tejido y por lo tanto pueden propagarse de manera más eficiente en el huésped (Hersh et al., 1999; Hilbi et al., 1998). En contraste, la inhibición de la apoptosis puede ser esencial para los patógenos intracelulares a la hora de establecer una infección crónica. El mecanismo antiapoptótico disparado por el patógeno en las células huésped infectadas enlentece la replicación microbiana y permite la persistencia de la infección.

Con el objeto de evaluar la capacidad de rLp95, rLIC11207 y rLIC12922 de inhibir o inducir apoptosis de neutrófilos se purificaron leucocitos polimorfonucleares (PMN) de sangre periférica. Luego de incubar 18 horas en presencia de las proteínas recombinantes, se realizó la tinción de NA/BrEt y se contaron las células viables y apoptóticas. Como control positivo se usó LPS el cual es un potente inhibidor de la apoptosis de estas células. A fin de evidenciar si el resultado obtenido es debido a las proteínas recombinantes y no al LPS se realizó una medida con las proteínas recombinantes junto con PMB.

Para corroborar la funcionalidad de la PMB se realizó también la incubación conjunta de los PMN con LPS y polimixina, obteniéndose resultados similares al control. 


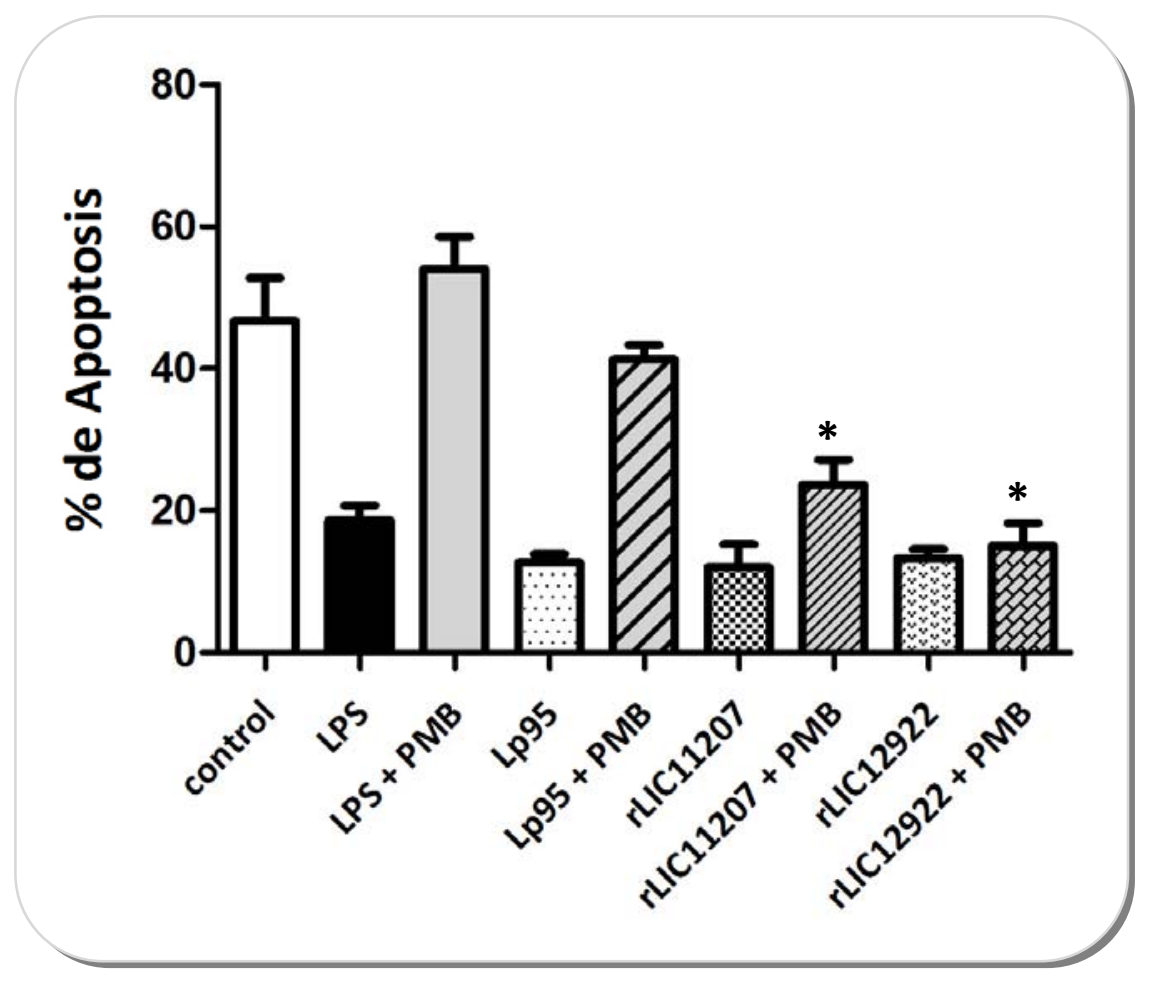

Figura 2.22 Inhibición de la apoptosis. Los PMN se incubaron con $25 \mu \mathrm{g}$ de cada proteína recombinante en presencia y en ausencia de PMB $(7 \mu \mathrm{g} / \mathrm{ml})$. Luego de 18 horas, se realizó la tinción de NA/BrEt y se determinó el porcentaje de células apoptóticas. Como control positivo se usó LPS con y sin PMB. Los resultados, expresados como \% de apoptosis corresponden a la media \pm 3DE de tres experimentos independientes. Solo rLIC11207 y rLIC12922 inhiben la apoptosis de polimorfonucleares de manera significativa. ${ }^{*} p<0,05$ vs control.

La figura 2.22 muestra que luego de 18 horas en cultivo, 50\% de los PMN sufren apoptosis. La presencia de cada una de las tres proteínas analizadas previno significativamente la muerte celular programada. Sin embargo, el efecto antiapoptótico de rLp95 fue completamente inhibido por la PMB; indicando que el mismo no es específico de la proteína sino del LPS contaminante. Si bien la PMB redujo el efecto antiapoptótico de la rLIC11207, el porcentaje de células apoptóticas fue significativamente menor con respecto al control. Teniendo en cuenta el bajo nivel de LPS presente en esta proteína $\left(8 \times 10^{-6} \mu \mathrm{g}\right.$ de LPS / $\mu \mathrm{g}$ de LIC11207) consideramos que la rLIC11207 protege a los PMN de la muerte celular programada. En forma contraria la elevada concentración de LPS presente en la 
muestra de rLIC12922, (117,6 $\mu \mathrm{g}$ de LPS/ $\mu \mathrm{g}$ de LIC12922) y la falta de efecto de la PMB indica que el efecto estaría asociado a la presencia de LPS.

\begin{tabular}{|c|c|c|c|}
\hline & LIC12690 & LIC11207 & LIC12922 \\
\hline Localización & $\begin{array}{l}\text { membrana } \\
\text { externa }\end{array}$ & $\begin{array}{c}\text { memb. externa / } \\
\text { interna }\end{array}$ & $\begin{array}{c}\text { espacio } \\
\text { periplásmico }\end{array}$ \\
\hline Péptido señal & + & + & + \\
\hline $\begin{array}{l}\text { Dominios } \\
\text { trasmembrana }\end{array}$ & + & + & - \\
\hline $\begin{array}{l}\text { Dominios } \\
\text { funcionales }\end{array}$ & DUF1544 & DUF1565 & $\begin{array}{c}\text { rotamasas, PRSA, } \\
\text { SurA }\end{array}$ \\
\hline Homología & $\begin{array}{l}\text { L. familia LEN } \\
\text { interrogans, }\end{array}$ & $\begin{array}{l}\text { L. interrogans, } L . \\
\text { borgpeterseni }\end{array}$ & $\begin{array}{c}\text { Leptospira spp. } \\
\text { Otras espiroquetas }\end{array}$ \\
\hline Gen en LIC & + & + & + \\
\hline Gen en PATOC & - & - & + \\
\hline Transcripto en LIC & + & + & + \\
\hline $\begin{array}{c}\text { Transcripto en } \\
\text { PATOC }\end{array}$ & - & - & + \\
\hline Inmunohistoquimica & ++ & ++ & ++ \\
\hline $\begin{array}{c}\text { Reactividad con } \\
\text { sueros de pacientes } \\
\text { enfermos }\end{array}$ & $+/-$ & ++ & - \\
\hline $\begin{array}{l}\text { Inhibición de la } \\
\text { apoptosis de PMN }\end{array}$ & $+/-$ & ++ & - \\
\hline Expresión de ICAM & - & - & + \\
\hline Expresión de ELAM & + & - & + \\
\hline Liberación de vWF & - & - & - \\
\hline
\end{tabular}

Tabla 2.6 Resumen de los resultados expuestos en este capítulo. 


\section{4.- Discusión}

Las proteínas previstas como proteínas de membrana externa han sido identificadas en las especies patogénicas L. interrogans serovar Lai (Ren et al., 2003) y Copenhageni (Nascimento et al., 2004b) y L. borpertsenii (Bulach et al., 2006). La mayoría de estas fueron consideradas como proteínas hipotéticas de función desconocida pero, debido a su localización putativa, se cree que éstas juegan un rol en la interacción huésped-patógeno. Es bien sabido que la adhesión y colonización del tejido del huésped por el patógeno es un evento temprano y crítico en el proceso de infección. Se han publicado varias adhesinas de matriz extracelular (ECM) leptospirales, entre ellas, una proteína de unión a fibronectina de $36 \mathrm{kDa}$ de identidad desconocida aislada de la membrana externa de una variante virulenta de leptospiras (Merien et al., 2000), proteínas de la familia Len (Stevenson et al., 2007) que incluye a LenA, formalmente llamada LfhA/Lsa (Barbosa et al., 2006; Nascimento et al., 2004a; Verma et al., 2006), las proteínas LigA/LigB (Choy et al., 2007), Lsa21 (Atzingen et al., 2008) y LipL32 (Hauk et al., 2008; Hoke et al., 2008).

Varias proteínas de activación endotelial han sido descriptas para espiroquetas patogénicas Borrelia spp. y Treponema spp. (Lee et al., 2000; Lee et al., 2005; Sellati et al., 1996; Sellati et al., 1995) y para la especie patogénica $L$. interrogans (Gomez et al., 2008; Vieira et al., 2007).

En este trabajo, se ha descripto por primera vez una proteína de $L$. interrogans, predicha como hipotética, que es capaz de activar la CAM endotelial, E-selectina. La proteína codificada por el gen lic12690, Lp95, es prevista como una proteína de membrana externa (Nakai and Kanehisa, 1991a) y como una lipoproteína (Juncker et al., 2003). Esta contiene un dominio conservado llamado DUF1554, el cual está presente en la familia de las proteínas Len (Stevenson et al., 2007). Sin embargo, en contraste con éstas que se dividen dentro de su propia familia, Lp95 aparece sola. El transcripto de lic12690 es conservado entre los 
serovares patogénicos más importantes de L. interrogans como Canicola, e Icterohaemorrhagiae y en $L$. borgpetersenii serovar Hardjo pero está ausente en $L$. interrogans serovar Pomona y Grippotyphosa y en la especie no patogénica $L$. biflexa. La proteína codificada por lic12690 fue expresada en E. coli como una proteína recombinante de $95 \mathrm{kDa}$, recibiendo el nombre de rLp95. La activación de la molécula de adhesión endotelial E-selectina por rLp95 fue demostrada claramente. Adicionalmente, el tratamiento de rLp95 con proteinasa K suprimió la inducción de E-selectina en HUVEC. En contraste con lo reportado previamente para otras proteínas recombinantes obtenidas tales como rLIC10365, rLIC10507, rLIC10508, rLIC10509 (Gomez et al., 2008), rLp95 no promovió la sobreexpresión de ICAM-1 y tampoco la liberación de Factor de von Willebrand.

Sellati y col. (Sellati et al., 1995) han demostrado que sólo las formas lipidadas de las proteínas recombinantes OspA de B. burgdoferi son capaz de promover la sobreexpresión de las CAMs. La expresión heteróloga de lipoproteínas en $E$. coli no resultó en la expresión de las proteínas recombinantes aciladas ya que para ello se requiere el plásmido que contiene la secuencia señal apropiada (Cullen et al., 2003). Previamente se ha demostrado que proteínas recombinantes de Leptospira fueron capaces de inducir el incremento de CAMs en HUVEC (Gomez et al., 2008; Vieira et al., 2007). Esta información sugiere que en nuestro modelo experimental la porción lipídica no está involucrada en esta interacción y creemos que este es el caso de Lp95.

La matriz extracelular juega un papel importante en la regulación de la adhesión celular eucariótica, como así también en la diferenciación, proliferación, forma y función. Se ha sugerido que la unión de leptospiras a la ECM se correlaciona directamente con la virulencia, de hecho al comparar las mismas especies virulentas y no virulentas pudo observarse una unión menos efectiva a la matriz por estas últimas. Se vió que Lp95 cuenta con la capacidad de unirse a laminina y fibronectina celular y plasmática (Atzingen et al., 2009). 
La proteína codificada por el gen lic11207, prevista como una proteína de membrana externa/interna presenta un dominio de función desconocida DUF1565. Si bien encontramos in sílico su homóloga en $L$. borgpeterseni, ésta se halla ausente en L. biflexa. El transcripto de lic11207 se encuentra presente en la especies patogénicas de L. interrogans serovares, Copenhageni, Icterohaemorraghie, Canicola y Pomona pero ausente en las especies pertenecientes a los serovares Grippotyphosa, Ballum, Tarassovi y tampoco en $L$. biflexa serovar Patoc. La proteína codificada por lic11207 fue expresada en E. coli como una proteína recombinante de 34 kDa. A diferencia de Lp95, LIC11207 no parecería inducir la activación del endotelio ya que no fue capaz de inducir la expresión de moléculas de adhesión como así tampoco la liberación de Factor de von Willebrand. Sin embargo, LIC11207 tendría un efecto antiapoptótico específico sobre los leucocitos PMN.

La proteína codificada por lic12922 fue predicha como una proteína localizada en el espacio periplásmico y presenta un dominio común a la superfamilia de las rotamasas, un dominio PrsA y un dominio SurA. La determinación de la estructura cristalina reveló la presencia de dos dominios proteicos homólogos a la chaperona periplásmica SurA de E. coli (Giuseppe et al., 2011). El dominio de parvulina al igual que PpiD carece de actividad peptidilprolilisomerasa (Giuseppe et al., 2011; Weininger et al., 2010). El análisis filogenético sugieren una estrecha relación entre rLIC12922 y las chaperonas PrsA (Vitikainen et al., 2004), PpiD (Weininger et al., 2010), y SurA (Bitto and McKay, 2002). Recientemente se ha demostrado que SurA es esencial para la virulencia de los uropatógenos E. coli, Salmonella y Shigella spp convirtiéndolo en un posible blanco para nuevas drogas contra los patógenos Gram negativos (Behrens-Kneip, 2010). La identificación de un homólogo de SurA en leptospiras y en otras espiroquetas podría contribuir al desarrollo de nuevos tratamientos contra las infecciones causadas por miembros de este phylum. Se encontraron los ortólogos 
de lic12922 en todas las especies de leptospiras secuenciadas hasta la fecha, esto sugiere una gran importancia de esta proteína en la supervivencia de las mismas.

El transcripto de lic12922 se halla presente tanto en las especies patogénicas serovares, Copenhageni, Icterohaemorraghie, Canicola, Pomona Grippotyphosa, Ballum, Tarassovi como en L. biflexa serovar Patoc. La proteína codificada por lic12922 fue expresada en E. coli como una proteína recombinante de $42 \mathrm{kDa}$. A pesar de producir una elevada inducción de la expresión de Eselectina y de ICAM-1, la alta cantidad de LPS presente en la muestra indica que probablemente tal efecto es generado en respuesta a la endotoxina y no debido a la acción de rLIC12922. Esta proteína no indujo la liberación de Factor de von Willebrand pero sí estimuló la inhibición de la apoptosis de los polimorfonucleares aunque tampoco se puede afirmar que este efecto sea de la proteína ya que probablemente sea causado por el LPS contaminante. Ambas afirmaciones cuentan con el soporte que la PMB revirtió sólo parcialmente el efecto observado. Recientemente se ha demostrado que rLIC12922 es incapaz de reaccionar con el plasminógeno para generar plasmina activa (Vieira et al., 2010).

La respuesta inmune desencadenada luego de la infección con leptospiras es generalmente, pero no exclusivamente, mediada por anticuerpos contra el LPS leptospiral (Adler and de la Pena Moctezuma, 2010). Las células endoteliales expresan CAMs constitutivamente, en bajos niveles, y esta expresión se ve regulada en respuesta a las citoquinas, LPS y lipoproteínas bacterianas (Kishimoto and Rothlein, 1994; Riley et al., 1992). Aunque la estimulación de CAMs ha sido demostrada en otras espiroquetas tales como Borrelia y Treponema (Lee et al., 2005; Sellati et al., 1996), ésta nunca ha sido evaluada para Leptospira spp. En este capítulo se demostró que ambas especies, patogénica y no patogénica de Leptospira promueven la sobreexpresión de ICAM-1 y E-selectina en HUVEC. Esto es lo esperado ya que el LPS es un fuerte inductor de CAMs. Sin embargo, la especie patogénica, L. interrogans promovió una mayor activación que la no patogénica L. biflexa lo que sugiere la presencia de otros factores dentro de las 
especies patogénicas involucrados en el aumento de la activación endotelial. Es de valor mencionar que tanto Lp95 como LIC11207 están ausentes en la especie saprófita L. biflexa.

Los antígenos proteicos codificados por lic12690, lic11207 y lic12922 fueron identificados tanto en el lúmen tubular como asociados a infiltrados celulares inflamatorios en riñones de hámsters infectados experimentalmente, sugiriendo la expresión de estas proteínas durante la infección del animal. Si bien las CAMs han sido reportadas como moléculas extracelulares que son empleadas por varias células del huésped en defensa contra la infección, también son empleadas por varios microorganismos, incluyendo protozoos, hongos, bacterias y virus, durante su patogénesis (Kerr, 1999). Tanto selectinas e integrinas como ICAM-1 y VCAM son estimuladas por Staphylococcus aureus y su rol sugerido fue mitogénico y con liberación masiva de citoquinas (Malik and Lo, 1996). En el caso de Mycobacterium tuberculosis, la activación del receptor del complemento 3 (CR3) e integrina CD11b/ CD18 fue el disparador de la fagocitosis CR3 sin estallido respiratorio (Ehlers and Daffe, 1998).

Al enfrentarse sueros de pacientes convalecientes de leptospirosis y pacientes sanos con las proteínas recombinantes pudo observarse una diferencia significativa de anticuerpos específicos contra rLp95. Esta diferencia fue mayor al titular los sueros frente a rLIC11207. No se encontraron diferencias en el título de anticuerpos específicos anti-rLIC12922 en pacientes convalecientes respecto a pacientes sanos, lo que concuerda con los bajos títulos de anticuerpos encontrados en hámsters infectados (Atzingen, 2010). Sumado a esto, al realizar la inmunización de hámsters con esta proteína y el posterior desafío con una cepa virulenta de $L$. interrogans serovar Copenhagenni, pudo observarse tan solo una protección del 30\% (Atzingen et al., 2010). 


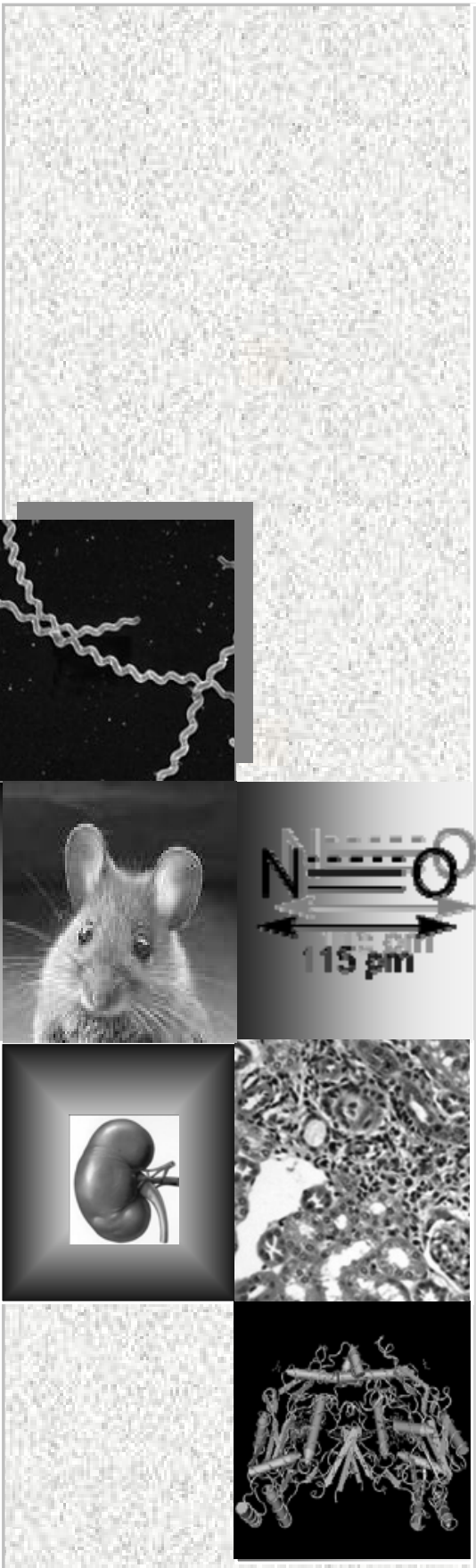

\section{Capítulo 3}

Mecanismos Patogénicos Involucrados El rol de la óxido nítrico sintasa inducible (iNOS) en la leptospirosis

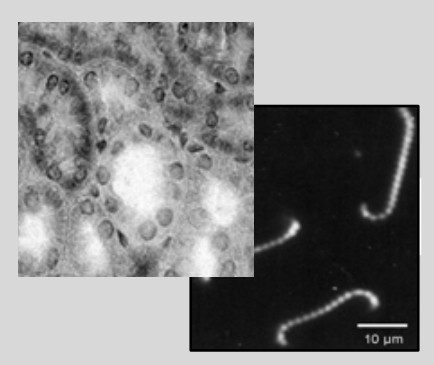




\subsection{Introducción}

El óxido nítrico (NO, del inglés nitric oxide), un radical libre gaseoso de vida media muy corta, es un potente mediador biológico en un gran número de eventos fisiológicos y patológicos (Knowles and Moncada, 1994).

El NO se sintetiza a partir de la L-arginina en presencia de oxígeno y de NADPH (nicotinamida adenina dinucleótido fosfato reducida), por medio de una familia de enzimas denominadas oxido nítrico sintasas (NOS). La reacción comprende la transferencia de electrones desde NADPH, a través de las flavinas FAD y FMN, desde el dominio de reductasa carboxiterminal, al hemo en el dominio oxigenasa amino terminal de la NOS, donde el sustrato L-arginina es oxidado a Lcitrulina y NO tal como se muestra en la Figura 3.1 (Andrew and Mayer, 1999).

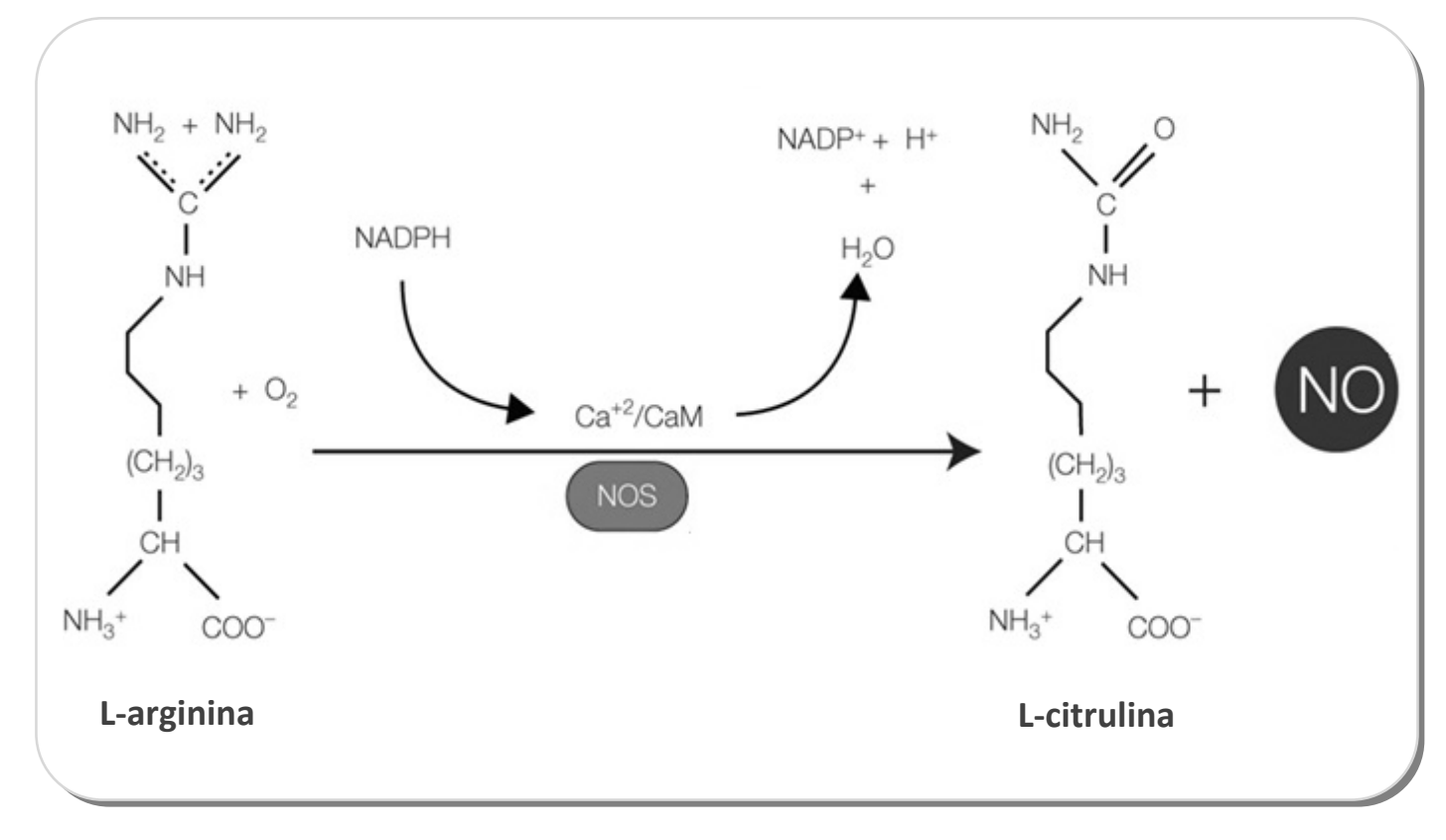

Figura 3.1 Reacción de síntesis del óxido nítrico a partir de L-arginina catalizada por las oxido nítrico sintasas.

Hasta ahora han sido aisladas y caracterizadas tres NOS que son producto de tres genes diferentes. Las tres isoformas varían en la localización celular, secuencia de aminoácidos, regulación y en sus papeles funcionales. Dos son esencialmente constitutivas (cNOS): la neuronal (nNOS o NOS1) y la endotelial 
(eNOS o NOS3) y una tercera, inducible (iNOS o NOS2). Las tres isoenzimas de NOS fueron inicialmente descriptas en tejidos diferentes. La nNOS fue descripta en cerebro y células nerviosas periféricas generando NO como neurotransmisor y neuromodulador; la eNOS en células del endotelio vascular principalmente regulando la dilatación vascular y por lo tanto la presión sanguínea (Nathan, 1992) y finalmente la iNOS, la cual es inducida por varios estímulos inflamatorios en macrófagos activados y otros tipos de células que juegan un rol en los procesos inflamatorios.

Normalmente, el nivel de NO es muy bajo (a nivel nanomolar) y resulta en su mayor parte de la expresión constitutiva de nNOS y eNOS. Ambas isoformas están reguladas principalmente a nivel postraduccional, permaneciendo inactivas hasta que los niveles intracelulares de calcio aumentan, éste se une a la calmodulina y el complejo activa la NOS (Figura 3.2).

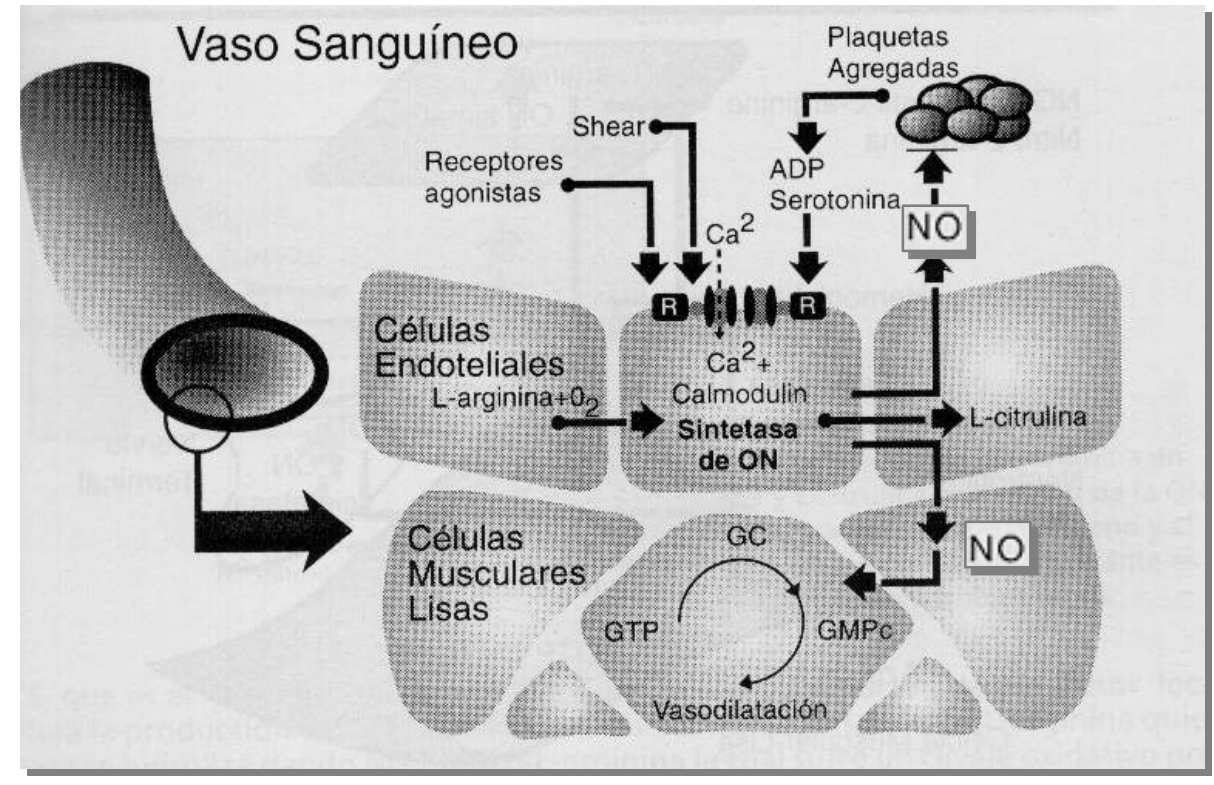

Figura 3.2 Síntesis del NO catalizada por eNOS en un mecanismo dependiente de calciocalmodulina (adaptado de De la Serna, 2004). 
En contraste, iNOS puede generar mayores niveles de NO en varios órdenes de magnitud (a nivel micromolar) por un período de tiempo relativamente prolongado (Kleinert et al., 2004). Varias moléculas, entre ellas el factor de necrosis tumoral $\alpha$ (TNF- $\alpha$ ), interleuquina $1 \beta$ (IL-1 $\beta$ ) y el componente lipopolisacárido de la pared de las bacterias Gram negativas (LPS) son capaces de mediar la regulación de la expresión de iNOS en muchos tipos celulares (Markewitz et al., 1993), incluyendo células tubulares renales (Yang, 2007) por medio de un mecanismo dependiente del NF-K $\beta$ (Figura 3.3).

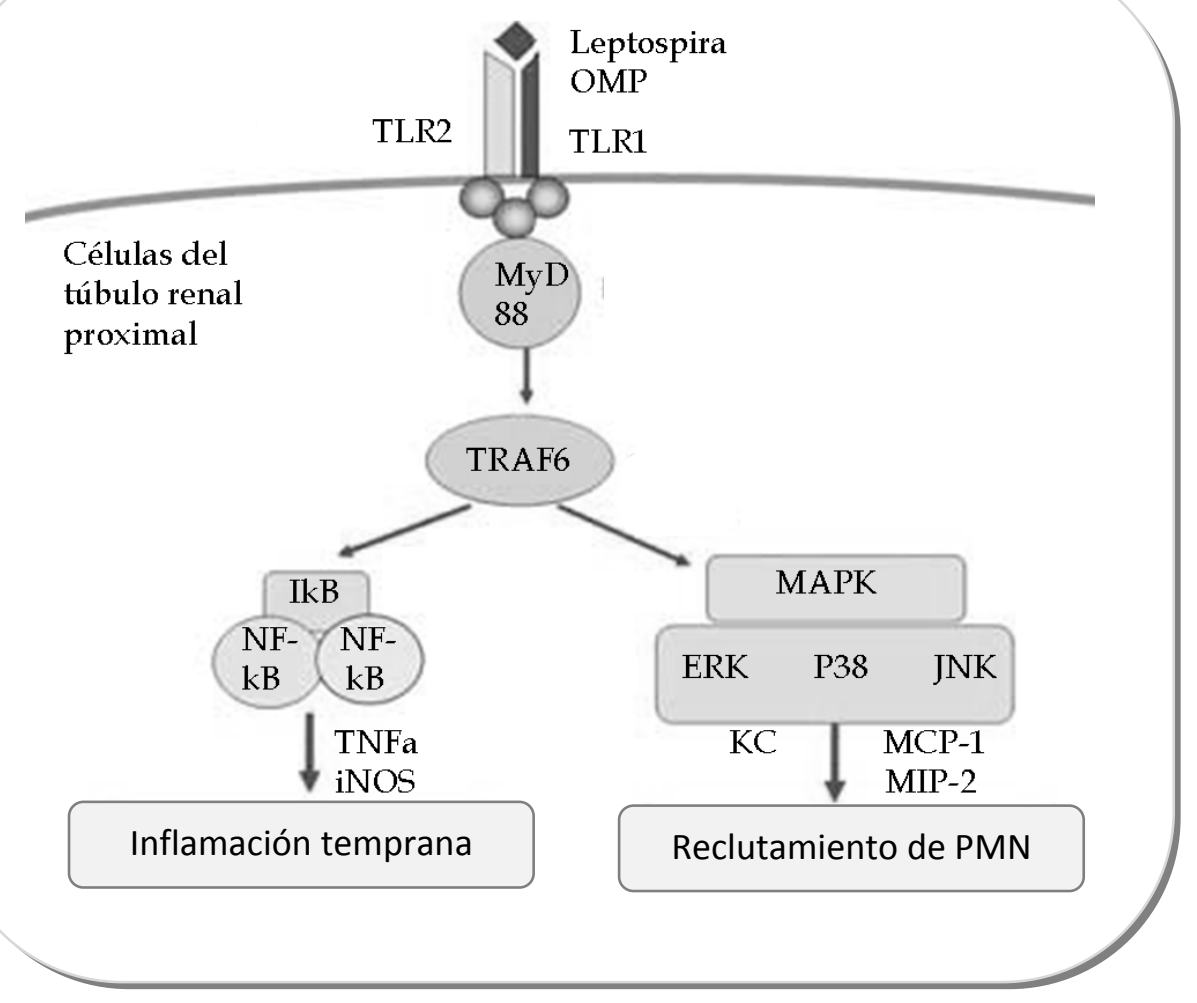

Figura 3.3 Inducción de la expresión de iNOS por leptospiras u OMPs leptospirales de manera dependiente del NF-K $\beta$ (Yang, 2007).

Se ha sugerido que como consecuencia de la producción de NO por los macrófagos en las reacciones citotóxicas de defensa del huésped existirían efectos inhibitorios en varios procesos incluyendo la contracción en músculo liso, el metabolismo y la síntesis de proteínas (Kunz et al., 1994), adquiriendo un rol de 
importancia en la patogénesis de diversas enfermedades (Gross and Wolin, 1995). Por ejemplo, el incremento en la producción de NO puede funcionar como una respuesta adaptativa en la inflamación hepática aguda y en la sepsis temprana (Farghali et al., 2002; Farzaneh-Far and Moore, 2001). En respuesta al LPS bacteriano, las células de Kupffer sintetizan varias citoquinas que estimulan indirectamente en el hepatocito la producción de NO (Curran et al., 1990) y sus productos finales estables nitritos y nitratos, que juegan un rol principal en el daño asociado con el shock endotóxico (Wang et al., 1994). Varios estudios demuestran que la producción de iNOS está implicada en enfermedades inflamatorias tanto agudas como crónicas (Ej. sepsis, shock séptico, disfunción vascular en diabetes, asma, artritis, esclerosis múltiple, gota y diversos tumores) (Lechner et al., 2005). Se ha demostrado que tanto Borrelias como Leptospiras inducen la expresión de iNOS en células de Kupffer (Marangoni et al., 2006). Además, se ha demostrado un aumento en la expresión de iNOS debido tanto a leptospiras como a sus lipoproteínas de superficie en células renales tubulares (Yang et al., 2001; Yang et al., 2002).

Como ya se ha mencionado, la disfunción renal es un síntoma cardinal en la leptospirosis. Se considera que el NO podría tener un papel preponderante en la respuesta del huésped, ejerciendo tanto acciones deletéreas como protectoras en la respuesta inflamatoria (Palaniappan et al., 2007), así como en la función renal (Zaki et al., 2005). Estudios preliminares realizados por nuestro grupo de trabajo indican que hay una marcada expresión de iNOS en los riñones de los animales inoculados con L. interrogans comparados con controles sanos (Gómez RM et al., 2007). Se han reportado hallazgos similares en el tejido pulmonar de pacientes con leptospirosis (Bonventre, 2007; Du et al., 2006; Gabbai et al., 2002). Sin embargo, se desconoce qué papel tendría el NO generado por iNOS en esta enfermedad.

En este capítulo se describirá el estudio realizado de la expresión de iNOS renal y su rol en un modelo experimental de leptospirosis. Para ello se utilizaron tanto ratones (Mus musculus, cepa $\mathrm{C} 3 \mathrm{H} / \mathrm{HeJ}$ ) como hámsters (Mesocricetus 
auratus) los cuales fueron inoculados con una especie virulenta de leptospira y tratados o no con 4-aminopiridina (4-AP), un inhibidor de la iNOS. Se analizó la expresión de iNOS, la correlación entre carga bacteriana renal y morbilidad/mortalidad y cómo la inhibición de iNOS moduló la respuesta humoral.

\subsection{Resultados}

\subsubsection{Virulencia}

Para confirmar la virulencia del cultivo empleado, un grupo de 3 hámsters fue inoculado con $10^{3}$ Leptospira interrogans serovar Copenhageni (LIC) cepa Fiocruz L1-130 mientras un grupo control fue inoculado con PBS. Los animales infectados se encontraron moribundos al 4 dpi y fueron sacrificados cosechándose ambos riñones. Un riñón se utilizó para la extracción de ADN a fin de demostrar la presencia de $L I C$ a nivel renal por PCR (Figura 3.4A). El otro riñón fue utilizado para análisis histopatológico. Se puede observar en la Figura 3.4B la presencia de nefritis intersticial, característica del daño producida por Leptospira interrogans en ese órgano.

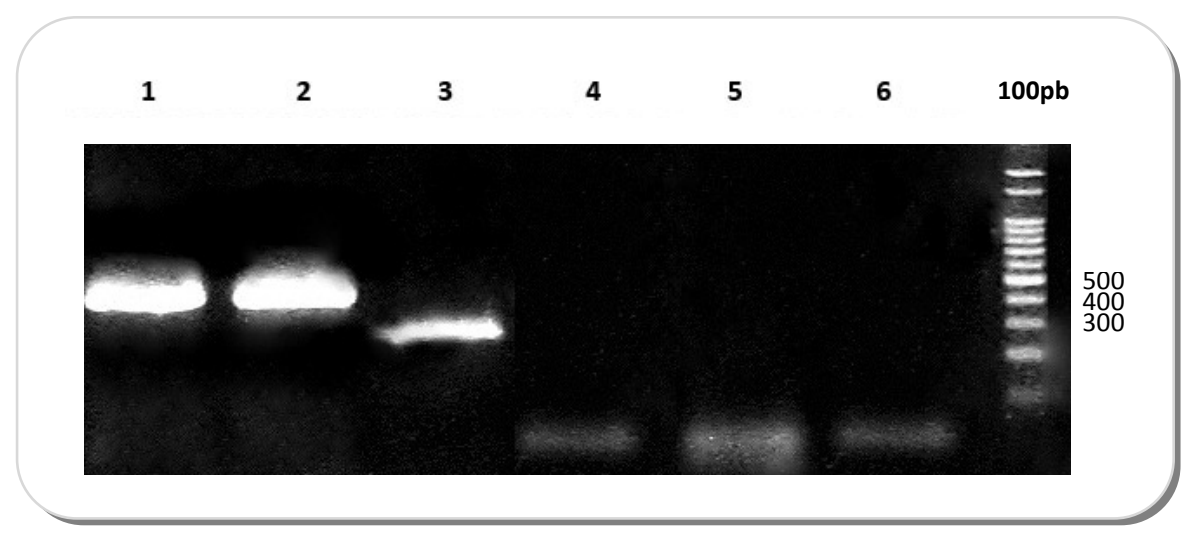

Figura 3.4A Resultados representativos del análisis por PCR del ADN extraído de riñón de un hámster inoculado con $10^{3}$ leptospiras al 4 dpi. Calle 1 y 2: bandas que corresponden a un fragmento de 6-actina $(450 \mathrm{pb})$ para el hámster infectado y para el control negativo, respectivamente. Calle 3: banda que corresponde a un fragmento del ARN16S (331 pb) de LIC del hámster inoculado. Calle 4: ausencia de banda en el animal control. Calle 5 y 6: controles negativos para 6-actina y para Leptospira usando $\mathrm{H}_{2} \mathrm{O}$ en lugar de templado respectivamente. 


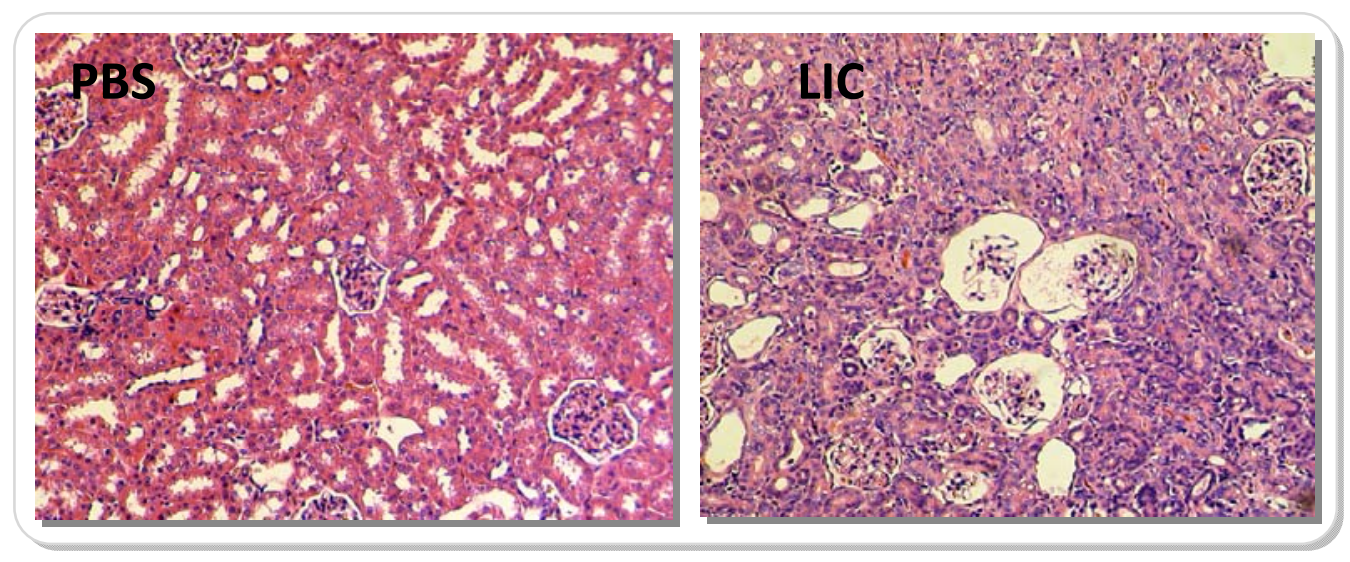

Figura 3.4B Análisis histopatológico. Tinción con hematoxilina/eosina de cortes de tejido renal de hámster al 4 dpi. A la izquierda puede observarse un riñón control de apariencia normal, mientras que a la derecha puede apreciarse una nefritis intersticial severa característica de la leptospirosis. Amplificación 240X.

\subsubsection{Elección del modelo animal}

Diversos modelos animales han sido empleados para el estudio de la leptospirosis. Mientras que los hámsters y los cobayos reproducen la infección aguda letal (Athanazio, 2008), las ratas representan el prototipo de modelo de infección persistente (Nally, 2005). Por el contrario, los ratones son portadores asintomáticos y se los considera hospedadores resistentes dependiendo de la edad, del inóculo y la cepa de ratón empleado (Nolte, 2004). Los modelos murinos tienen la ventaja de contar con un mayor número de herramientas genéticas e inmunológicas disponibles para la investigación básica. La falta de conocimiento acerca del desarrollo de la infección en las distintas especies murinas impulsaron el desarrollo de numerosos estudios en ratones de diversas cepas, transgénicos y/o mutantes (Cockerill, 2003) a fin de encontrar un modelo experimental de leptospirosis.

Con el objeto de elegir la cepa murina adecuada para ser usada en un modelo experimental de leptospirosis se procedió a infectar tres grupos de ratones de diferentes cepas con $10^{6}$ leptospiras. Si bien no se observó mortalidad 
ni morbilidad, el análisis por PCR del ADN extraído de tejido renal al 14 dpi indica la presencia de leptospiras en riñón tanto en los ratones Balb/c como en los $\mathrm{C} 3 \mathrm{H} / \mathrm{HeJ}$ (Figura 3.5). Los hallazgos histológicos mostraron infiltrados inflamatorios en los riñones de ratones $\mathrm{C} 3 \mathrm{H} / \mathrm{HeJ}$ infectados, mientras que en las otras dos cepas no se observó daño alguno (Figura 3.6A, 3.6B, 3.6C).

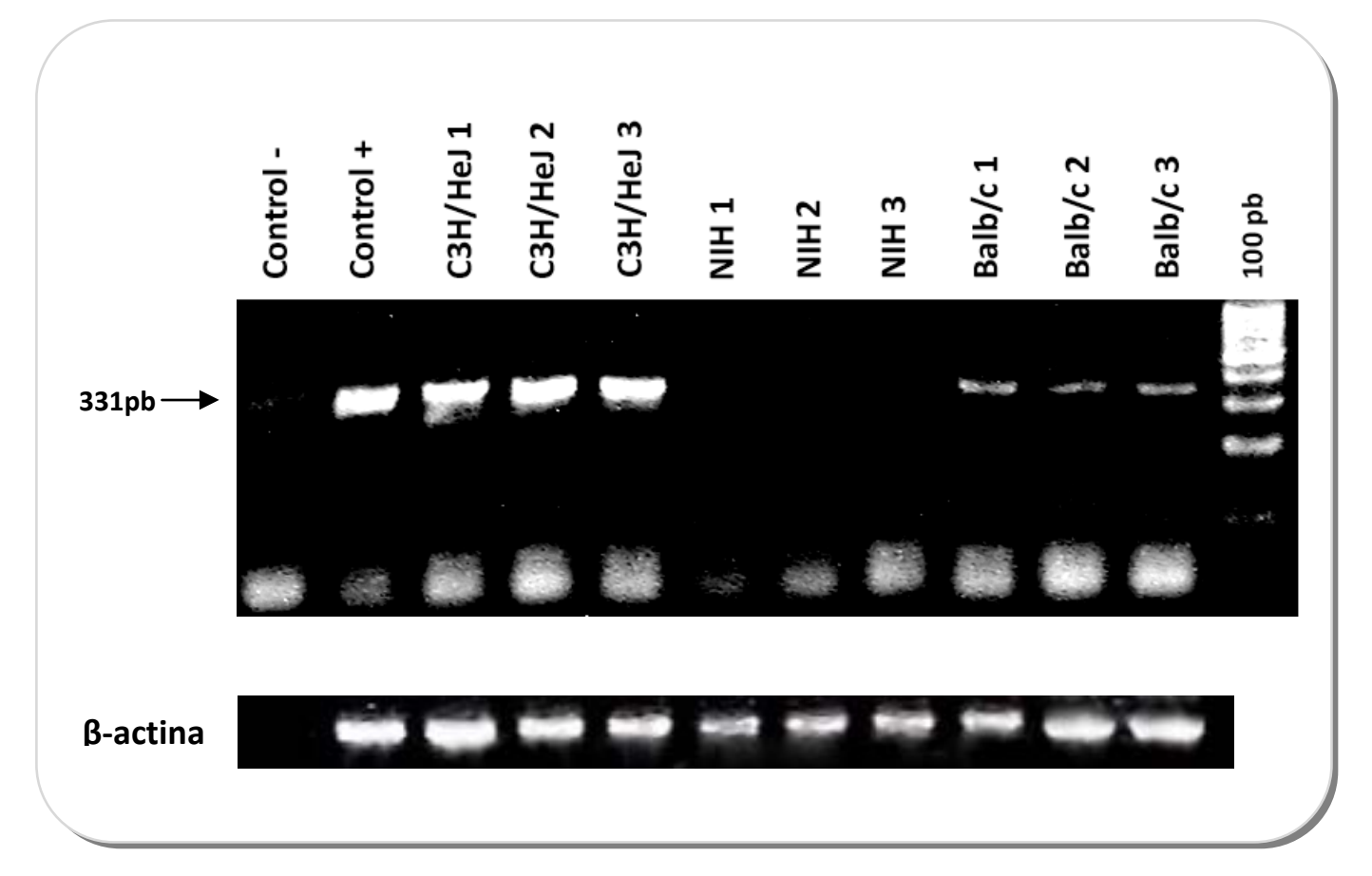

Figura 3.5 Análisis por PCR del ADN extraído de riñón al 14 dpi de distintas especies murinas infectadas con $10^{6}$ leptospiras. Se observa la presencia de una banda de $331 \mathrm{pb}$ correspondiente a un fragmento del ARN16S tanto en los ratones BALB/C como en los $\mathrm{C} 3 \mathrm{H} / \mathrm{HeJ}$ y la ausencia de la misma en los ratones $\mathrm{NIH}$. En todas las calles se observa la presencia de una banda correspondiente a un fragmento de B-actina validando el proceso de extracción de ADN. Como control positivo se usó un templado extraído de un hámster infectado con Leptospira de alta virulencia. 

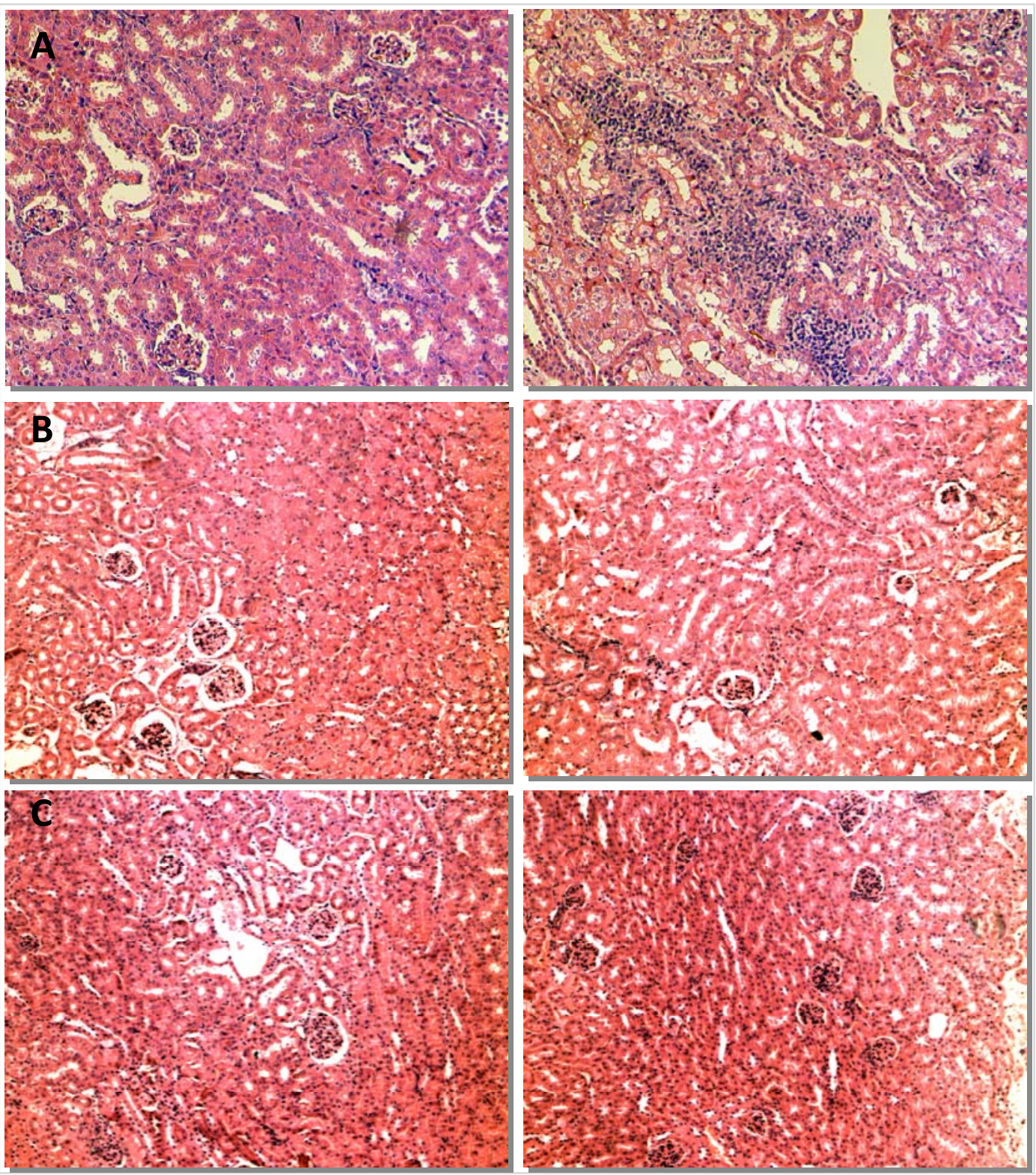

Figura 3.6 Análisis histopatológico. Tinción con hematoxilina-eosina de tejido renal murino. A la izquierda tejidos pertenecientes a los grupos control mientras que a la derecha se ubican los cortes de animales infectados. El panel superior A muestra tejidos de ratones $\mathrm{C} 3 \mathrm{H} / \mathrm{HeJ}$, el $\mathbf{B}$ de ratones NIH y el $\mathbf{C}$ de ratones Balb/c. Solo se observa nefritis intersticial en los ratones $\mathrm{C} 3 \mathrm{H} / \mathrm{HeJ}$ infectados (panel A a la derecha), siendo de apariencia normal el resto. Amplificación 240X. 
En base a estos resultados los ratones $\mathrm{C} 3 \mathrm{H} / \mathrm{HeJ}$ fueron elegidos como modelo experimental de leptospirosis.

\subsubsection{Expresión renal de iNOS}

Con el objetivo de conocer si la infección por leptospiras aumenta la expresión de iNOS a nivel renal, se procedió a realizar un estudio comparativo de los niveles de esta enzima entre animales infectados con LIC y otros animales control no infectados. En primera instancia se realizó un análisis por PCR en tiempo real (qPCR) que dio como resultado un aumento de la transcripción del ARNm de iNOS en ratones $\mathrm{C} 3 \mathrm{H} / \mathrm{HeJ}$ al $14 \mathrm{dpi}$. Resultados similares se obtuvieron en hámsters al 7 dpi (Figura 3.7 A, B, C y D). El análisis por western-blot confirmó ambos resultados (Figura $\mathbf{3 . 7}$ E). Como era de esperar, el análisis inmunohistoquímico demostró un aumento en la expresión de iNOS al comparar animales infectados con animales sin infectar y además precisó que iNOS se encontraba tanto en el citoplasma de células presentes en el infiltrado inflamatorio como en el de las células tubulares renales (Figura 3.7 F). Concomitantemente, se observó un incremento significativo en los niveles séricos de nitritos/nitratos en los animales infectados con respecto a los animales del grupo control ( $15 \pm 8$ vs. $175 \pm 21 \mu \mathrm{M}, \mathrm{P}<0.05)$. 

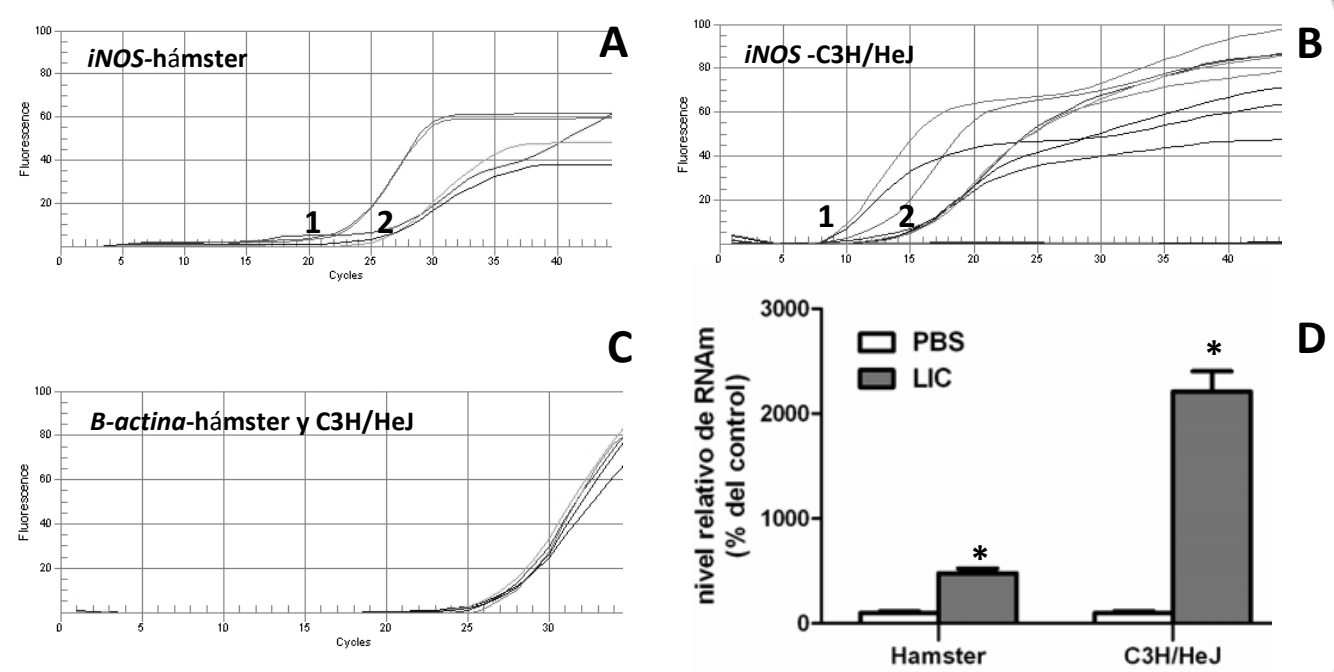

Figura 3.7 Expresión de iNOS. Curvas de qPCR para el transcripto de iNOS. Primer y segundo salto corresponden a hámsters infectados y sin infectar, respectivamente (A) y a $\mathrm{C} 3 \mathrm{H} / \mathrm{HeJ}$ infectados y sin infectar, respectivamente (B). Curvas para B-actina de todas las muestras (C). El análisis por qPCR muestra un aumento en la expresión del transcripto de iNOS en el riñón de animales infectados comparados con los no infectados (D). Los riñones de los hámsters y de los ratones fueron cosechados al 7 y $14 \mathrm{dpi}$, respectivamente. Estos resultados son representativos de tres experimentos diferentes. Valores de $p<0,05$ se indican con un *.

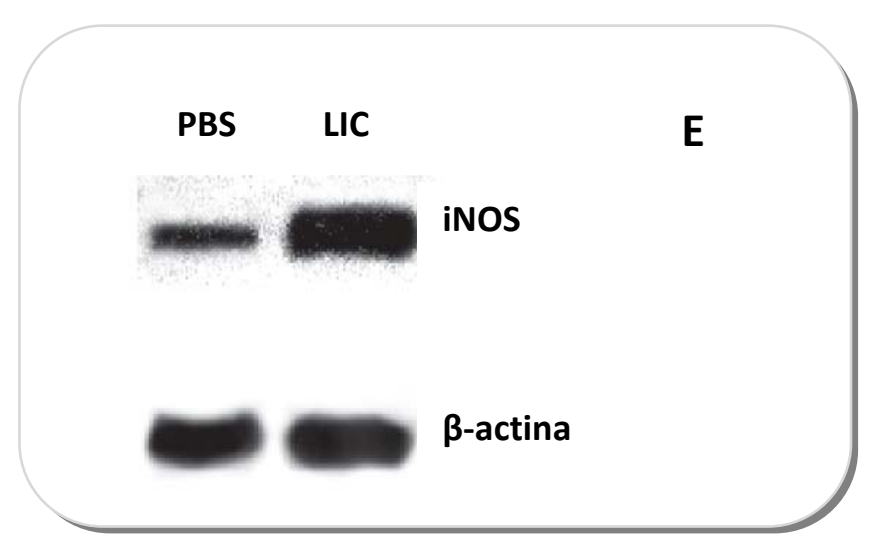

Figura 3.7E. Western-blot. Análisis de la expresión renal de iNOS en hámsters al 7 dpi. $\beta$-actina fue usado como control de carga (housekeeping). Luego de la transferencia, bloqueo y lavado la membrana se incubó con anti-iNOS o anti-actina 1 hora a 37으 y por último se incubó con IgG conjugada a HRP anti-conejo o anti-ratón, respectivamente, en las mismas condiciones. Las bandas de iNOS reveladas con ECL mostraron una mayor intensidad en el pool de animales infectados con respecto al pool control, lo cual se correlaciona con un aumento en la expresión de dicha enzima en los primeros. Similares resultados se obtuvieron con ratones $\mathrm{C} 3 \mathrm{H} / \mathrm{HeJ}$. 


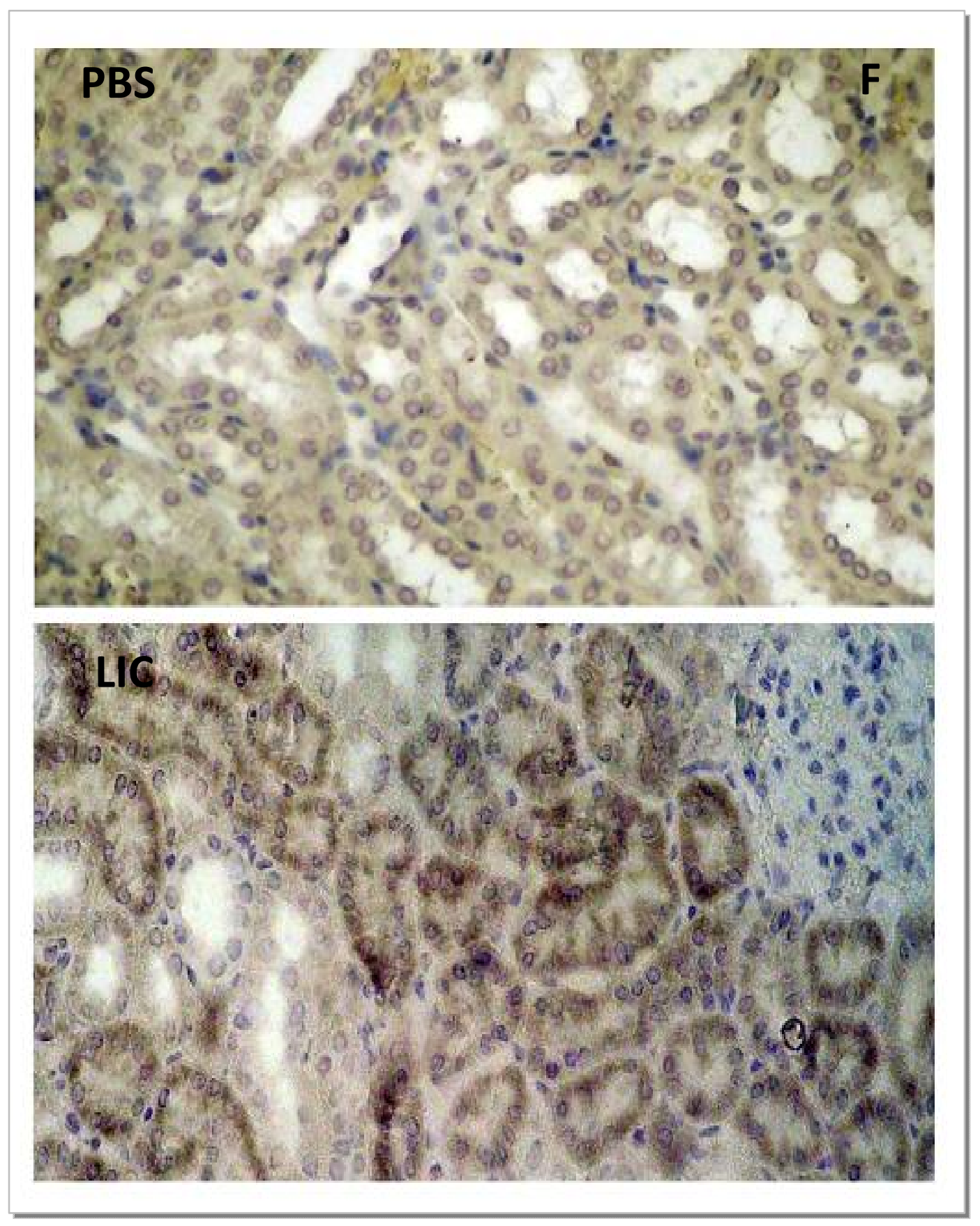

Figura 3.7F Tinción inmunohistoquímica. Riñón de hámster sin infectar (panel superior) o infectado (panel inferior). Las secciones fueron incubadas con un anticuerpo policlonal anti-iNOS durante 1 hora a temperatura ambiente y luego, tras varios lavados, se incubó con el anticuerpo secundario conjugado a un polímero de dextrán unido a peroxidada durante 20 minutos a temperatura ambiente. El revelado se realizó mediante el agregado de diaminobencidina $/ \mathrm{H}_{2} \mathrm{O}_{2}$ (DAB), sustrato de la peroxidasa. Los preparados muestran un incremento de antígeno iNOS tanto en las células tubulares como en el citoplasma de los infiltrados inflamatorios presentes en los tejidos de animales infectados con LIC. Aumento de 250X. Resultados similares se obtuvieron con ratones $\mathrm{C} 3 \mathrm{H} / \mathrm{HeJ}$. 
Para estudiar en mayor profundidad el rol de iNOS en la leptospirosis se compararon varios parámetros entre animales infectados tratados y sin tratar con un inhibidor de iNOS.

\subsubsection{Curso clínico}

La infección con LIC indujo una mortalidad del 100\% en hámsters al 7 dpi y un $20 \%$ en los ratones $\mathrm{C} 3 \mathrm{H} / \mathrm{HeJ}$ al 14 dpi (Figura 3.8A y 3.8B). Todos los hámsters infectados que recibieron tratamiento con 4-AP murieron un día antes mientras que los ratones $\mathrm{C} 3 \mathrm{H} / \mathrm{HeJ}$ que recibieron dicho tratamiento incrementaron su mortalidad al $60 \%$ al 14 dpi. Durante el período de observación no ocurrió muerte de los animales sin infectar ya sea tratados o sin tratar con 4-AP.

\section{A}

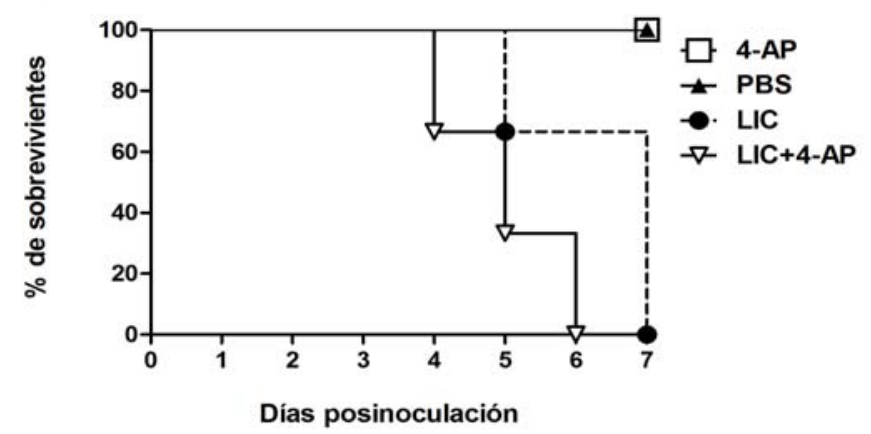

B

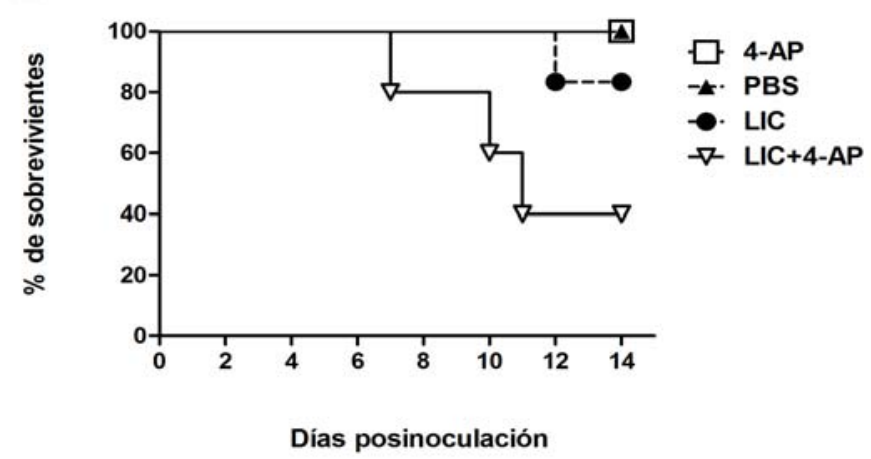

Figura 3.8 Curva de sobrevida. Porcentaje de hámsters (A) y $\mathrm{C} 3 \mathrm{H} / \mathrm{HeJ}$ (B) sobrevivientes organizados en 4 grupos: sin infectar y sin tratar (triángulo negro), tratados con 4-AP (cuadrado), inoculados con LIC (círculo) y tratados con 4-AP e inoculados con LIC (triángulo blanco). Puede observarse que el tratamiento con 4-AP produce la muerte de todos los hámsters al 6 dpi y aumenta la mortalidad a un $60 \%$ al $14 \mathrm{dpi}$ en ratones $\mathrm{C} 3 \mathrm{H} / \mathrm{HeJ}$. 


\subsubsection{Carga Bacteriana}

Para estudiar si la inhibición de la iNOS tendría algún tipo de impacto sobre la carga bacteriana renal, se realizaron extracciones de ADN total del tejido renal y se analizaron por qPCR. Los resultados mostraron que tanto en los hámsters como en los ratones al 7 y $14 \mathrm{dpi}$, respectivamente, la carga bacteriana presente en riñón era mayor en los animales infectados y tratados con 4-AP que en los infectados y sin tratar con 4-AP (Figura 3.9).

A

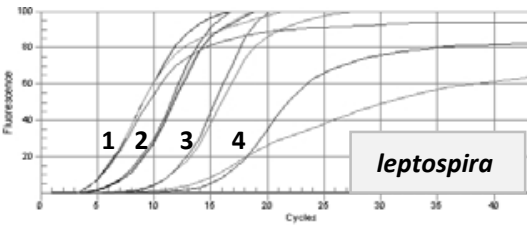

C

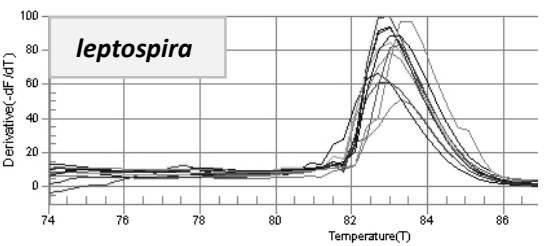

B

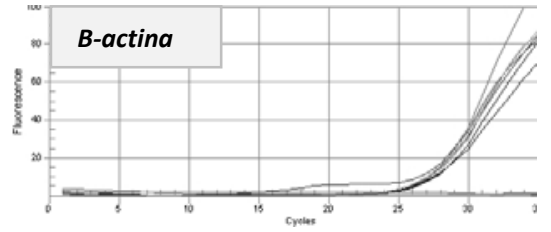

D

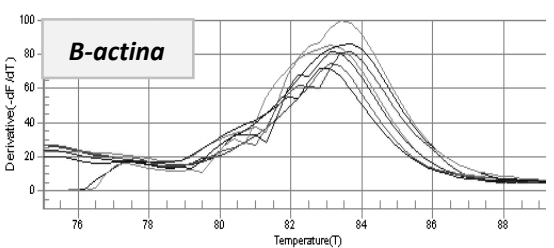

E

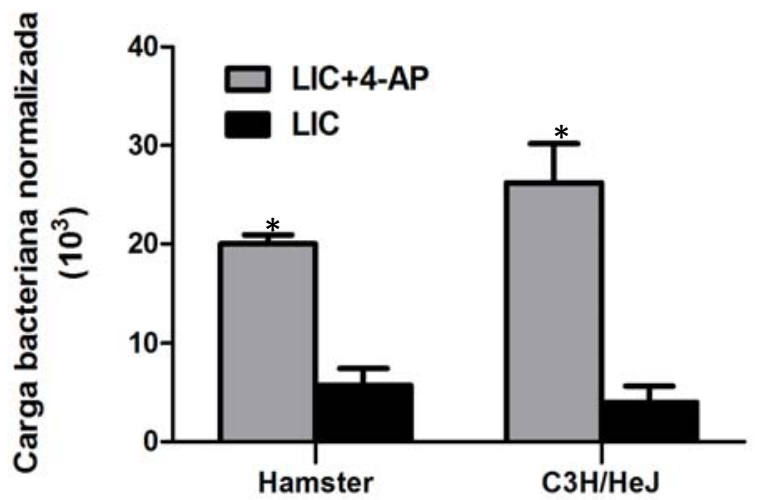

Figura 3.9 Carga bacteriana. Cuantificación por qPCR del ADN leptospiral en riñones de animales tratados con 4-AP y $\sin$ tratar, infectados con $10^{2}$ leptospiras (hámsters) y $10^{7}$ (ratones) analizados al 7 (hámsters) y al $14 \mathrm{dpi}$ (ratones). Tres porciones de éste órgano fueron analizadas por qPCR. A. Curva de qPCR para el fragmento de $331 \mathrm{pb}$. Primer y segundo salto: hámsters y $\mathrm{C} 3 \mathrm{H} / \mathrm{HeJ}$ infectados y tratados con 4-AP, respectivamente. Tercer y cuarto salto: hámsters y $\mathrm{C} 3 \mathrm{H} / \mathrm{HeJ}$ infectados y sin tratar con 4-AP, respectivamente. B. Curva de qPCR para un fragmento de actina de $158 \mathrm{pb}$ en muestras de hámsters y $\mathrm{C} 3 \mathrm{H} / \mathrm{HeJ}$. C y D. Curvas de melting para los fragmentos de leptospira y $\beta$ actina, respectivamente. E. Gráfico de barras para carga bacteriana/ng de ADN de hámster/ratón. Las barras representan la media \pm error estándar (SE) de los ensayos realizados en grupos de tres hámsters/ratones. Valores de $p<0.05$ están indicados con un * 


\subsubsection{Hallazgos histológico}

Se llevó a cabo un examen histológico para evaluar si el aumento de la mortalidad y de la carga bacteriana observada luego de la inhibición de iNOS correlacionaba con la patología. Como se esperaba, los ratones no infectados ya sea tratados o sin tratar no presentaron ningún hallazgo histopatológico (Figura 3.10A y 3.10B). En contraste, en los animales infectados se observó nefritis tubulointersticial. En general, se apreció una arquitectura tanto medular como cortical relativamente conservada y unos pocos glomérulos contraídos. También pudo verse que algunos túbulos contenían material proteináceo junto con eritrocitos en su luz. Cerca de los grandes vasos se notó ocasionalmente un infiltrado inflamatorio. Los hallazgos histopatológicos en ratones fueron similares a los observados en hámsters y en ambos casos, se vio una mayor intensidad en los animales infectados y tratados con 4-AP (Figura $3.10 \mathrm{C}$ y 3.10D).
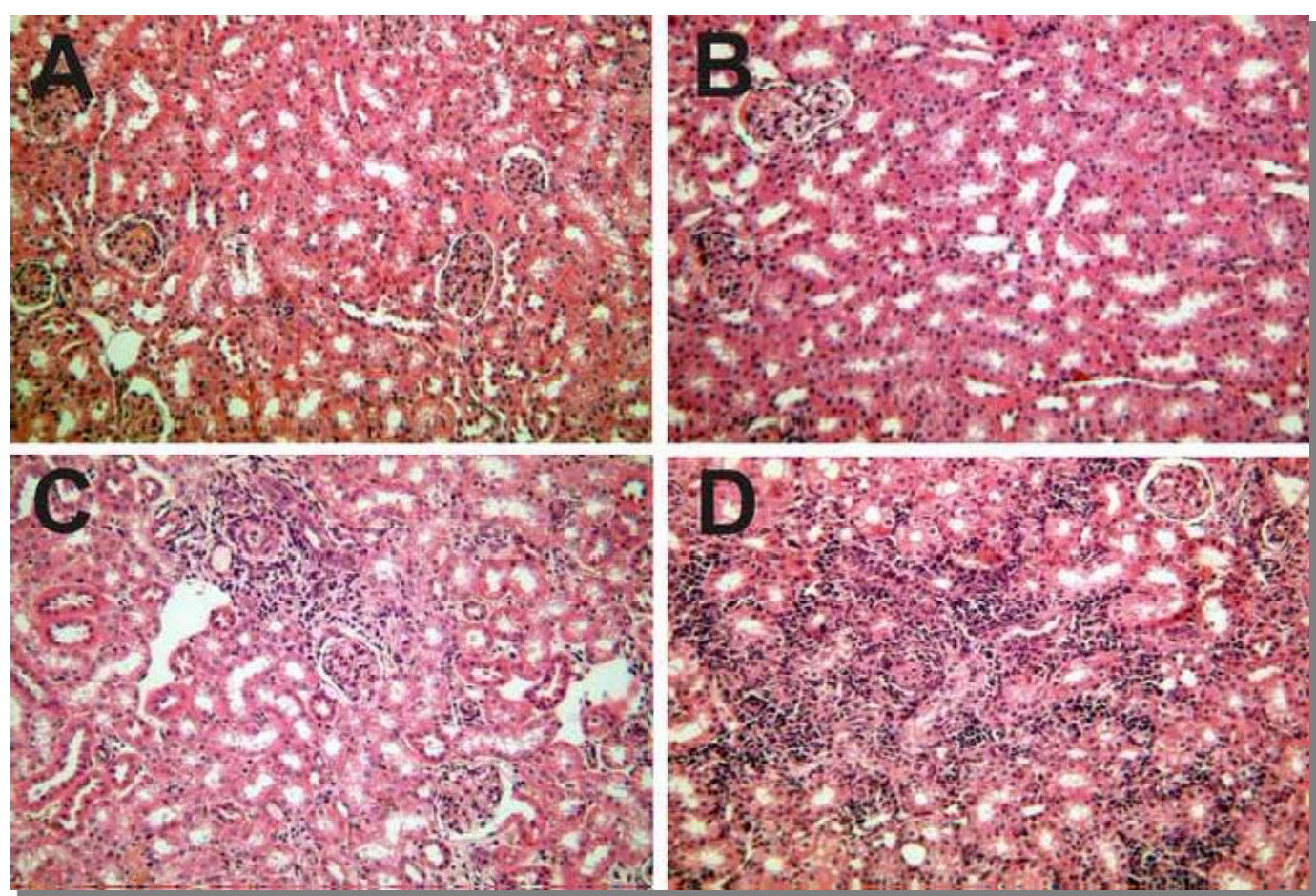

Figura 3.10 Histopatología. Tinción representativa de hematoxilina-eosina a los 14 dpi de riñones de $\mathrm{C} 3 \mathrm{H} / \mathrm{HeJ}$ (A) sin infectar y sin tratar, (B) tratados con 4-AP, (C) infectados con LIC y (D) infectados con LIC y tratados con 4-AP. A y B muestran apariencia normal. En C se observa nefritis intersticial leve, mientras que en $\mathbf{D}$ puede observarse nefritis intersticial de severidad intermedia. Aumento 250X. 


\subsubsection{Respuesta Humoral}

A fin de estudiar un mecanismo de defensa crítico que participa en la leptospirosis, como la respuesta humoral específica, se llevó a cabo un ensayo de ELISA realizado con leptospiras muertas el cual permite detectar los niveles de inmunoglobulinas $\mathrm{M}$ y $\mathrm{G}$ específicas.

Los resultados mostraron que los niveles de IgM séricos de ratones $\mathrm{C} 3 \mathrm{H} / \mathrm{HeJ}$ a los $14 \mathrm{dpi}$ fueron mayores en los animales infectados y tratados con PBS que los infectados y tratados con 4-AP. En ambos casos los animales control presentaron niveles mínimos. A su vez, los niveles de IgM resultaron ser mayores que los niveles de IgG a los $14 \mathrm{dpi}$.

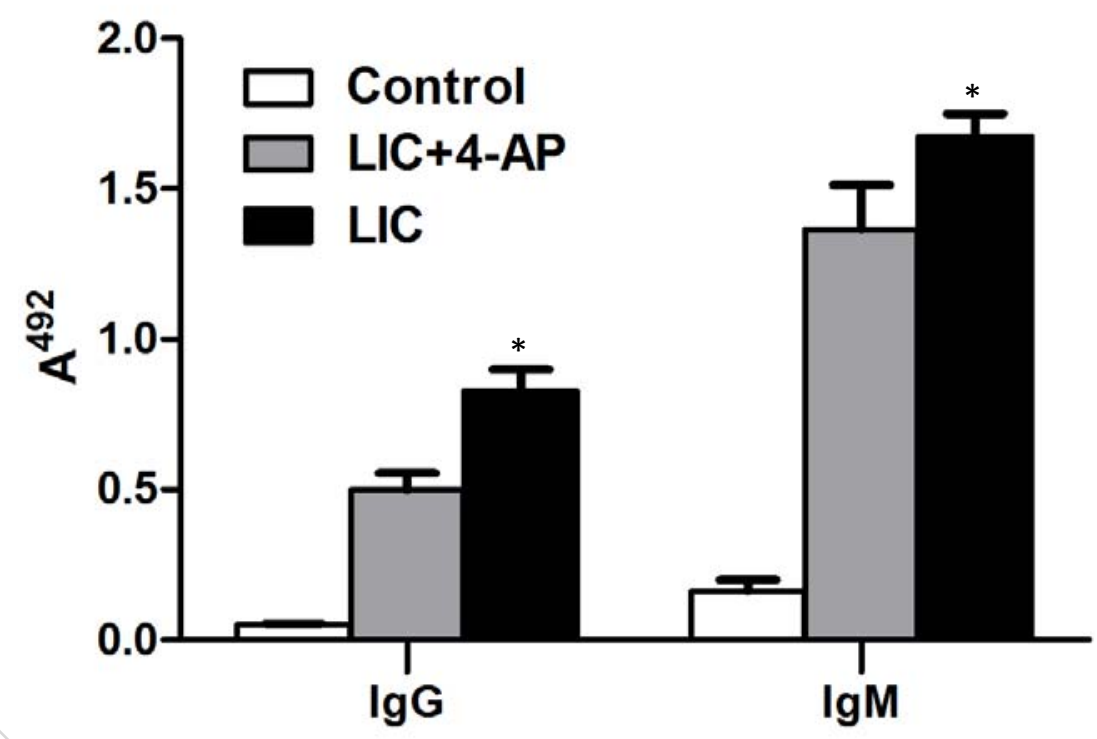

Figura 3.11 Respuesta humoral. Ensayo de ELISA realizado para detectar anticuerpos IgG e IgM anti-LIC en el suero de ratones $\mathrm{C} 3 \mathrm{H} / \mathrm{HeJ}$ infectados, con y sin tratamiento con 4-AP. El suero de animales no infectados fue usado como control negativo. Las placas de microtitulación fueron cubiertas con $10^{6}$ LIC inactivadas por calor e incubadas con diluciones de sueros. Los datos se representan como la media de la absorbancia a $492 \mathrm{~nm} \pm$ la desviación estándar realizados por triplicado y corresponden a una dilución $1 / 20$ de cada suero. Valores de $\mathrm{P}<0.05$ se indican con un $*$. 
El estudio fue repetido para IgG con sueros de hámsters infectados con y sin tratamiento. Los resultados mostraron un título mayor de anticuerpos anti-LIC IgG en los animales infectados y tratados con PBS que los infectados y tratados con 4-AP y que en ambos casos los animales control presentaron los niveles mínimos de anticuerpo (Figura 3.12).

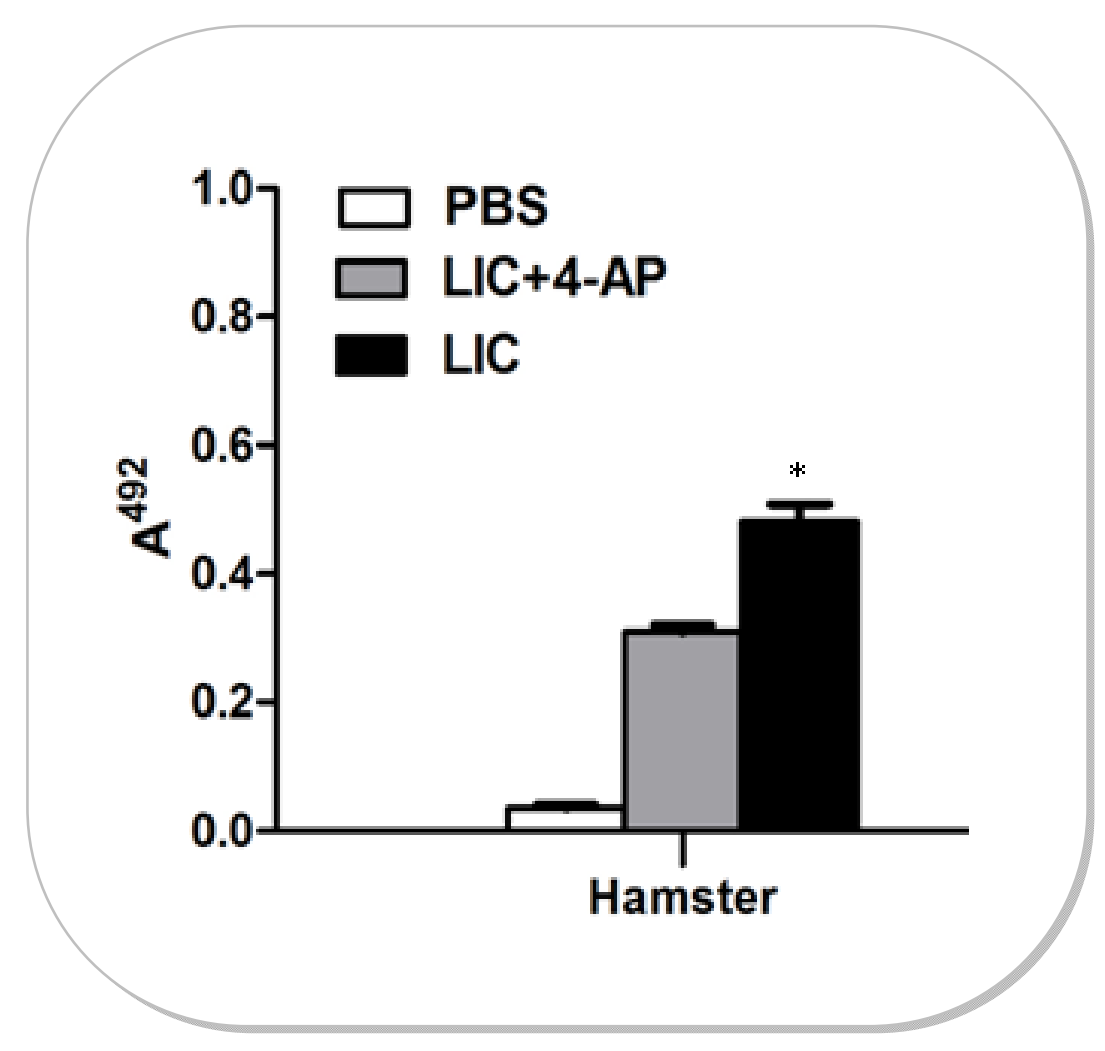

Figura 3.12 Respuesta humoral. Un ensayo ELISA fue realizado para detectar anticuerpos IgG anti-LIC en el suero de hámsters infectados, con y sin tratamiento con 4-AP. El suero de animales sin infectar fue usado como control. Placas de microtitulación fueron cubiertas con $10^{6}$ LIC inactivadas por calor e incubadas con diluciones de sueros. Los datos de representan como la media de la absorbancia a $492 \mathrm{~nm} \pm$ la desviación estándar realizados por triplicado de la dilución $1 / 20$ de cada suero. Valores de $p<0.05$ se indican con un *. 


\section{3- Discusión}

La cepa de leptospira empleada fue capaz de inducir mortalidad, enfermedad e incremento en la expresión de iNOS en forma significativa, tanto en hámsters como en ratones $\mathrm{C} 3 \mathrm{H} / \mathrm{HeJ}$. En hámsters se usó un inóculo de menor título ya que el mismo es suficiente para producir una cinética de infección similar a la que se produce en humanos (Silva et al., 2008), razón por la cual éstos, junto con los cobayos, son empleados en las pruebas de virulencia (Ko et al., 2009). Debido a que los hámsters murieron en la primera semana de infección surgió la necesidad de encontrar un modelo experimental que nos permitiera estudiar la enfermedad en la etapa leptospirúrica. En las cepas Balb/c y NIH se encontraron discreta a nula carga bacteriana y patología en riñón, respectivamente, resultando ser más resistentes a la infección y por lo tanto no fueron elegidas como modelos experimentales. En contraste, la significativa carga bacteriana e histopatología renal en los ratones $\mathrm{C} 3 \mathrm{H} / \mathrm{HeJ}$ los convirtieron en un excelente modelo de leptospirosis.

Los receptores tipo toll (TLRs) reconocen componentes microbianos conservados tales como el LPS, lipopéptidos o ADN bacteriano hipometilado para activar la respuesta inmune innata que tiene por objetivo eliminar los microorganismos del huésped. Los ratones $\mathrm{C} 3 \mathrm{H} / \mathrm{HeJ}$ son portadores de una mutación que inactiva el gen t/r4 volviéndolos susceptibles a la leptospirosis (Pereira et al., 1998), ya que los TLR4 se hallan involucrados en el clearance de Leptospira (Viriyakosol et al., 2006) aunque los mecanismos involucrados no están aclarados todavía. Se ha demostrado que el LPS de Leptospira es reconocido tanto por los TLR4 como por los TLR2 murinos (Nahori et al., 2005; Que-Gewirth et al., 2004; Werts et al., 2001) mientras que las lipoproteínas de Leptospira únicamente son reconocidas por los TLR2 de las células epiteliales renales murinas (Yang et al., 2006). 
La inducción de la expresión de iNOS en riñones, no solo en el infiltrado inflamatorio sino también en las células tubulares, particularmente de la médula externa, era esperada ya que previamente se demostró que leptospiras vivas son capaces de inducir la expresión de iNOS en las células de Kupffer (Marangoni et al., 2006) del mismo modo que lo hace la proteína de membrana externa LipL32 en células renales (Yang et al., 2001; Yang et al., 2002). También se sabe que pacientes con leptospirosis presentan niveles altos de oxido nítrico en suero (Maciel et al., 2006). Además se observó un aumento de expresión de iNOS en pulmones, bazo y riñón de ratones con shock endotóxico (Kan et al., 2004) y en estructuras vasculares y tubulares de la médula externa de ratas tratadas con LPS (Chou et al., 2002).

A pesar de que la leptospirosis es una importante causa de falla renal aguda, los mecanismos de disfunción renal aun no han sido claramente estudiados (Yang, 2007). La patofisiología involucrada en la disfunción tubular proximal, concuerda con la entrega distal de sodio y consecuentemente, con la excreción de potasio en el túbulo distal intacto (Magaldi et al., 1992) con un defecto en el cotransportador de $\mathrm{Na}^{+} / \mathrm{K}^{+} / \mathrm{Cl}^{-}$(NKCC2) (Lin et al., 1999). A nivel histológico, la nefritis tubulointersticial, con presencia de edema e infiltrados celulares en el área tubulointersticial, es la principal manifestación durante la falla renal aguda (Ooi et al., 1972; Penna et al., 1963). Varios estudios realizados por Yang y col., han permitido elucidar los mecanismos de la injuria tubulointersticial causada por la infección de leptospira. Ellos demostraron que extractos de OMP de leptospiras en cultivos de células epiteliales del túbulo renal murino activaban el NF-kB (Yang, 2000). Otros estudios demostraron que LipL32, la principal lipoproteína de membrana externa de leptospiras patogénicas producían un incremento en la expresión de enzimas y citoquinas proinflamatorias como iNOS, la proteína quimoatractante de monocitos 1 (CCL2/MCP-1), CCL5 (o RANTES) que atrae células $T$, eosinófilos y basófilos, y TNF- $\alpha$ en las células del túbulo proximal 
murino (Yang et al., 2002), a través de una vía de señalización que involucra TLR2 (Yang et al., 2006) (Figura 3.3).

Los ratones infectados con LIC que adicionalmente recibieron 4-AP mostraron una nefritis tubulointersticial de mayor intensidad que aquellos sólo infectados, lo cual es consistente con las observaciones previas dónde la inhibición de iNOS resultó agravar la sepsis inducida por Streptococcus del grupo B (Puliti et al., 2004) y Staphylococcus aureus (Sakiniene et al., 1997) en contraste con la mejoría observada luego de la inhibición de iNOS en la nefritis neurotóxica (Bremer et al., 1997) y en la nefrectomía experimental (Fujihara et al., 2002). En conjunto, estos resultados sugieren que el beneficio en la inhibición de iNOS podría depender de si la enfermedad es de origen infeccioso. Debido a que LipL32 gatilla la expresión de iNOS en manera dosis dependiente (Yang et al., 2002), una posible explicación del mecanismo involucrado podría ser la mayor carga bacteriana presente en los tejidos renales de los animales tratados con 4-AP. Esta alta carga bacteriana podría ser consecuencia tanto de la reducción de la inhibición de la replicación provocada por el NO como así también de producirse el cambio en la respuesta inmune hacia una respuesta del tipo T-helper 1 (Th1) tras la administración crónica de bloqueadores selectivos de iNOS (Gabbai et al., 2002). De hecho, se observó una respuesta humoral disminuida, la cual es críticamente importante en la limitación de la diseminación de las leptospiras (Adler and Faine, 1977; Chassin et al., 2009) junto con el agravamiento del infiltrado intersticial, lo que posiblemente conduce a un deterioro funcional.

Dado que el NO ha sido relacionado con importantes funciones patofisiológicas en las células tubulares de riñón, incluyendo la regulación positiva del transporte de $\mathrm{Na}^{+}$y $\mathrm{HCO}_{3}{ }^{-}$(Wang, 2002), sería posible que el aumento en la expresión de iNOS tuviese un rol importante en la disfunción renal observada durante la leptospirosis (Liang and Knox, 2000; Yang et al., 2001) ya que se ha visto que la inhibición de cNOS por el NO generado por iNOS luego de la administración de LPS provocaba disfunción renal en ratas (Schwartz et al., 1997). 
Es más, la nefritis túbulointersticial autoinmune ha sido asociada con una reducción progresiva del índice de filtración glomerular, donde la inducción de iNOS con producción elevada de NO podría contribuir activamente a los cambios funcionales observados en las etapas iniciales de la enfermedad, probablemente por la inhibición de la actividad normal de la eNOS que conduce a una vasoconstricción irrestricta por parte de las hormonas vasopresoras, tales como angiotensina II y catecolaminas y en consecuencia reducen el flujo del plasma renal y la tasa de filtración glomerular (Gabbai et al., 2002).

Se ha asignado un papel importante tanto al estrés oxidativo y nitrosativo concomitante como a la subsecuente formación de peroxinitritos en la disfunción renal posterior. El barrido de peroxinitritos usando seleno-compuestos orgánicos como esbselen provee protección contra la injuria isquémica (Goligorsky et al., 2002). Desde que otros estudios demostraron el papel de NO/iNOS en la patogénesis de la leptospirosis (Marangoni et al., 2006), los resultados presentados revelan nuevos mecanismos patogénicos en esta enfermedad y alientan al estudio patofisiológico del efecto de la inhibición de iNOS en la función renal en la leptospirosis y podrían permitir el desarrollo de nuevas estrategias terapéuticas. 


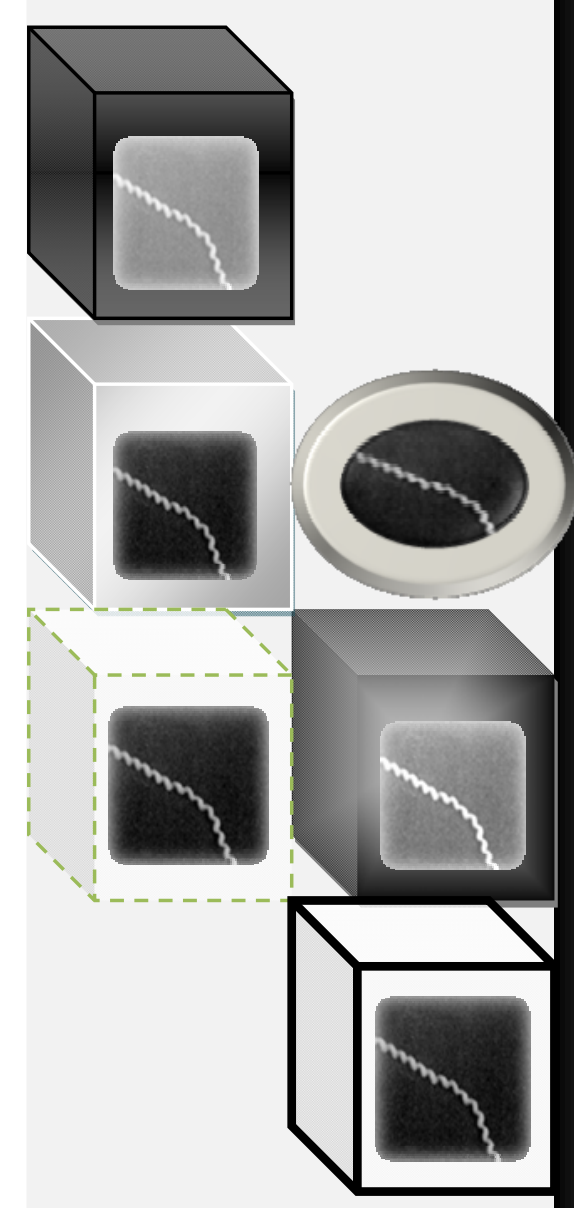

\section{Capítulo 4}

Conclusiones y perspectivas 


\subsection{Conclusiones Generales}

En el capítulo 2 se describe a Lp95 como una nueva proteína que posee la habilidad de estimular al menos una CAM endotelial, es reconocida por el suero de pacientes con leptospirosis, su expresión in vivo ha sido corroborada en tejido renal durante la leptospirosis experimental y que, en otros estudios, exhibe propiedades de unión a la matriz extracelular (Atzingen et al., 2009). En conjunto estos resultados sugieren que Lp95 podría ser un factor de patogenicidad y podría ser estudiada como candidato vacunal.

Se describe LIC11207 como una nueva proteína capaz de producir una inhibición de la apoptosis de los polimorfonucleares y de ser reconocida por el suero de pacientes convalecientes. Se demostró su presencia en tejido renal de hámsters infectados experimentalmente con leptospiras. Su capacidad antiapoptótica, la ausencia de su homóloga en la especie saprófita y su elevada inmunogenicidad sugieren que LIC11207 es un importante factor de virulencia y podría ser estudiada como candidato vacunal.

Se contribuye a la caracterización de LIC12922, demostrando su presencia en tejidos infectados. Si bien los resultados obtenidos indican un aumento en la expresión de ICAM-1 y ELAM-1 y una inhibición de la apoptosis de los polimorfonucleares parecería que tal efecto es producido por la cantidad de LPS contaminante, incapaz de ser inhibido por la PMB. LIC12922 es reconocida de igual modo por el suero de los pacientes sanos y enfermos. El análisis estructural y evolutivo (Giuseppe, 2010) llevan a que se la postule como una chaperona periplásmica involucrada en la biogénesis de las OMPs de Leptospira spp. Debido a que sus homólogas fueron identificadas en todos los genomas espiroquetales secuenciados hasta la fecha se asume que esta proteína podría estar implicada en la biogénesis de las OMPs de todo el Phylum.

Finalmente la caracterización de estas tres proteínas leptospirales contribuye a generar herramientas moleculares útiles para el diagnóstico, 
prevención y estudio de mecanismos patogénicos involucrados en la leptospirosis, cumpliendo de este modo con los objetivos propuestos en la primera etapa de este trabajo.

En la segunda etapa de este trabajo se estudiaron los mecanismos patogénicos involucrados en la leptospirosis, en particular el rol que cumple iNOS en esta infección. En hámsters y ratones $\mathrm{C} 3 \mathrm{H} / \mathrm{HeJ}$ infectados con leptospiras se observó una regulación positiva de la expresión de iNOS tanto a nivel transcripcional como traduccional. La inhibición específica de iNOS incrementó la mortalidad y la carga bacteriana renal, agravó la nefritis tubulointersticial y redujo la respuesta humoral específica. De acuerdo con estos resultados, concluimos que la expresión de iNOS y su producto el NO juegan un rol importante en la disfunción renal observada en la leptospirosis.

\subsection{Perspectivas}

Acorde con los resultados obtenidos, tanto rLp95 como rLIC11207 podrían ser buenos candidatos vacunales. En un futuro cercano sería conveniente realizar la inmunización con estas proteínas recombinantes y el posterior desafío con leptospiras virulentas a fin de determinar si las mismas confieren protección. En este sentido, LIC12922 ha sido recientemente reportada como no o poco protectora (Atzingen et al., 2010). Adicionalmente, la generación de mutantes por manipulación genética utilizando procedimientos descriptos en forma relativamente reciente por el $\operatorname{Dr} \mathrm{M}$. Picardeau y col. también podría contribuir a una mejor comprensión del rol de estas proteínas en la patogénesis de la infección.

Debido a que el NO juega un rol importante en la leptospirosis los resultados obtenidos sugieren realizar ensayos con inhibidores altamente selectivos de iNOS $\mathrm{y} / \mathrm{o}$ con moléculas neutralizadoras de peroxinitritos 
(scavenging peroxynitrite), tales como el compuesto $1400 \mathrm{~W}$ y el ebselen, respectivamente, y de este modo estudiar en mayor detalle el papel de iNOS en la leptospirosis y eventualmente desarrollar nuevas estrategias terapéuticas contra la leptospirosis. 


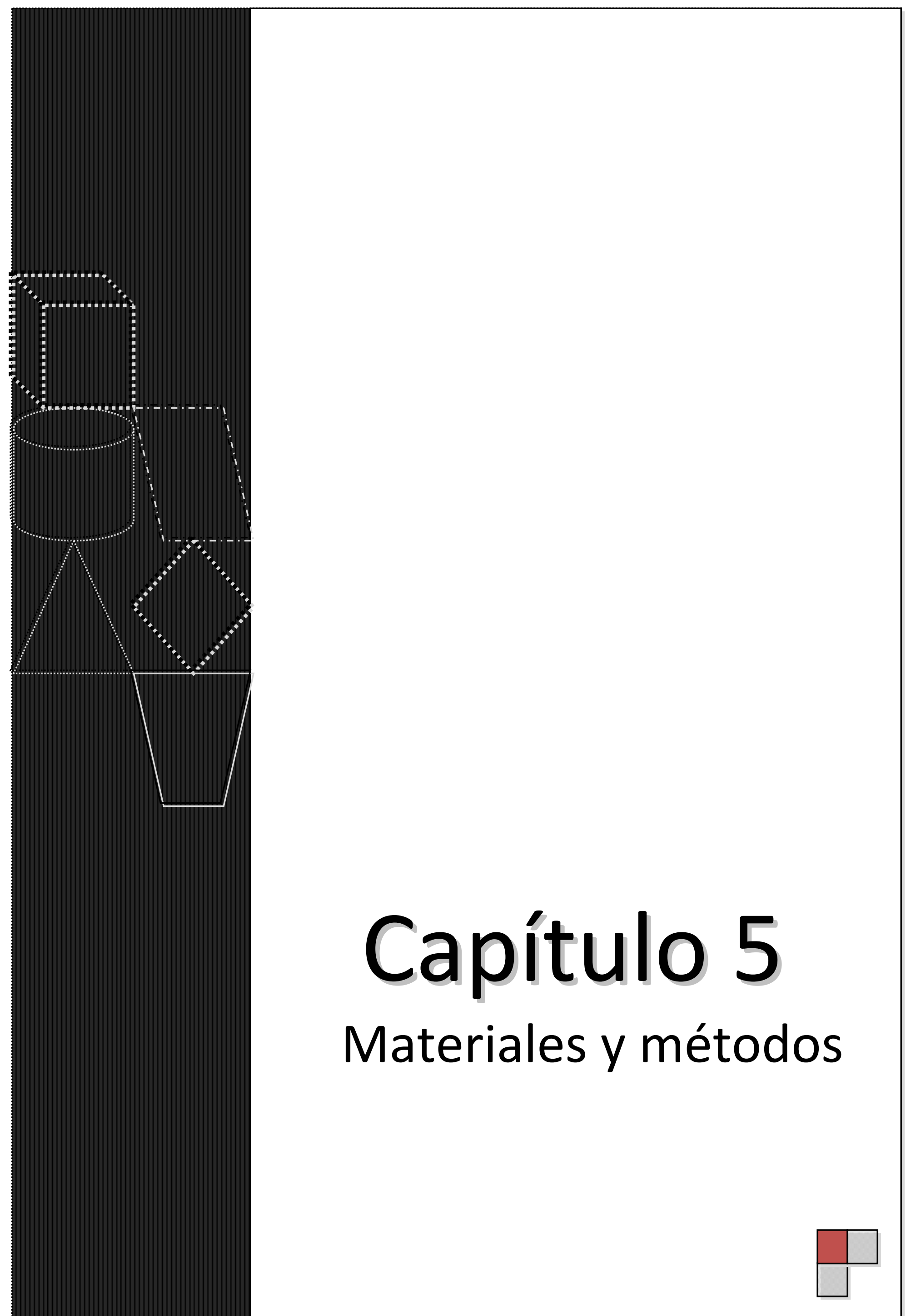




\subsection{Productos químicos y enzimas}

Los reactivos químicos utilizados, así como los reactivos de biología molecular fueron de grado analítico. Todas las macromoléculas, incluyendo la proteína usada como control, BSA, fueron provistas por Sigma Chemical Co. (St. Louis, MO, USA) excepto cuando se aclare. El agua utilizada fue destilada o bidestilada (según necesidad), deionizada y esterilizada por autoclave.

\subsection{Medios}

\section{LB (Luria-Bertani)}

En este medio se crecieron todas las cepas de E. coli. Se preparó con triptona $10 \mathrm{~g} / \mathrm{L}$, extracto de levaduras $5 \mathrm{~g} / \mathrm{L}, \mathrm{NaCl} 10 \mathrm{~g} / \mathrm{L}$. Para la preparación de placas, se añadió $15 \mathrm{~g} / \mathrm{L}$ de agar. Para realizar el medio de las células BL21 SI, se procedió en forma idéntica pero sin el agregado de $\mathrm{NaCl}$. Para la selección de colonias positivas de un plásmido determinado, se utilizó como medio LB con el agregado de ampicilina (Amp, $100 \mu \mathrm{g} / \mathrm{ml}$ ) ya que todos los plásmidos utilizados poseen resistencia a este antibiótico.

\section{EMJH (Ellinghausen-McCullough-Johnson-Harris)}

Los cultivos de leptospiras fueron realizados en medio EMJH base (Difco) suplementado con albúmina, polisorbato 80 y factores de crecimiento adicionales para leptospira (Difco) acorde a las indicaciones del fabricante. El medio base contiene cloruro de amonio como fuente de nitrógeno y tiamina como factor de crecimiento. La capacidad de buffer es provista por el fosfato disódico y el fosfato

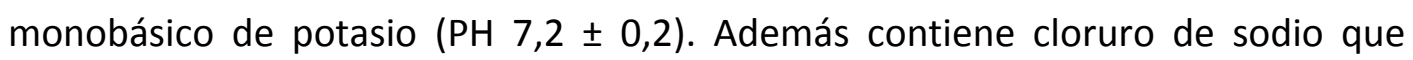
aporta iones esenciales para el crecimiento. 
RPMI (Roswell Park Memorial Institute)

Para el crecimiento de las células HUVEC se utilizó medio RPMI 1640 (Sigma) suplementado con $10 \%$ de suero fetal bovino, $90 \mathrm{mg} / \mathrm{ml}$ de heparina, suplemento de crecimiento de células endoteliales (ECGS), $2 \mathrm{mM}$ de piruvato de sodio, $2 \mathrm{mM}$ de L-glutamina y antibióticos $(100 \mathrm{U} / \mathrm{ml}$ de penicilina y $100 \mu \mathrm{g} / \mathrm{ml}$ estreptomicina).

\subsection{Cepas bacterianas utilizadas}

\section{Cepas de Leptospira spp.}

La cepa Fiocruz L1-130 de Leptospira interrogans serovar Copenhageni utilizada fue originalmente aislada de un paciente con leptospirosis severa en un brote epidémico en San Salvador de Bahía, Brasil, en 1996 y ha sido descripta previamente (Ko et al., 1999). Se prepararon cultivos en medio EMJH líquido y semisólido a $30^{\circ} \mathrm{C}$ y en aerobiosis. La virulencia de la LIC fue mantenida por pasajes sucesivos en hámsters machos (Mesocricetus auratus) de 21-28 días de edad. Las cepas de L. interrogans serovares Canicola (Hond Utrechet IV), Grippotyphosa (Moskva V), Icterohaemorrhagiae (RGA) y Pomona (Pomona); las de L. borgpetersenii serovar Hardjo (Hardjoprajtino), Tarassovi (Perepelicin) y Ballum (Castellonis Castellon 3) y las de Leptospira biflexa serovar Patoc (Patoc 1) fueron cedidas gentilmente por la Dra. Bibiana Brihuega (INTA, Castelar) y crecidas en medio $\mathrm{EMJH}$ a $30^{\circ} \mathrm{C}$, en condiciones aeróbicas en nuestro laboratorio.

\section{Cepas de Escherichia coli}

Las cepas E. coli utilizadas en el presente trabajo se describen genotípicamente en la Tabla 5.1 
Tabla 5.1 Cepas de $E$. coli empleadas en este trabajo

\begin{tabular}{|ccc|}
\hline Cepa & Genotipo relevante & Utilización \\
\hline DH5 $\boldsymbol{\alpha}$ & F- $\phi 80$ lacZ $\Delta \mathrm{M} 15 \Delta($ lacZYA-argF) U169 endA1 recA1 hsdR17 & Amplificación de \\
& $($ rk-, mk+) supE44 thi-1 gyrA96 relA1 pH: oA & vectores, clonado \\
BL21 & F- ompT hsdSB(rB-, mB-) gal dcm endA1 lon- proUp::T7 & Expresión \\
SI & RNAP::malQ-lacZ (TetS) & \\
\hline
\end{tabular}

\subsection{Animales}

Hámsters (Mesocricetus auratus) de 3 a 4 semanas de edad fueron comprados en la Comisión Nacional de Energía Atómica (Ezeiza, Argentina). Los ratones $\mathrm{C} 3 \mathrm{H} / \mathrm{HeJ}$ de 3 semanas de edad fueron comprados en Biol (Buenos Aires, Argentina). Los ratones Balb/c y NIH fueron comprados en la Facultad de Veterinaria, UNLP (La Plata, Argentina). Todos los animales recibieron comida y agua ad libitum. Todos los procedimientos experimentales fueron acordes a los principios éticos vigentes para el trato de animales de experimentación.

\subsection{Verificación de la virulencia}

Tres hámsters de 3 semanas de edad fueron inoculados ip con $10^{3}$ leptospiras o con PBS y usados como grupo control. Al 4 dpi los animales infectados presentaban signos de enfermedad y fueron sacrificados $y$ se les extrajo el riñón a partir del cual se realizó análisis histopatológico, extracción de ADN para medida de carga bacteriana renal por qPCR y cultivo del mismo en medio EMJH líquido suplementado, a $30^{\circ} \mathrm{C}$ en condiciones de aerobiosis y oscuridad. 


\subsection{Elección del modelo animal}

Se utilizaron dos grupos de 4 animales cada uno por cada cepa (Balb/c, NIH у $\mathrm{C} 3 \mathrm{H} / \mathrm{HeJ})$. A uno de los grupos se le administró ip $10^{6}$ leptospiras por animal y al segundo grupo $500 \mu \mathrm{l}$ de PBS. Al 14 dpi se sacrificaron todos los animales y se les extrajo ambos riñones. Se colocó uno en paraformaldehído al 4\% para posterior análisis histopatológico y otro en Trizol para realizar la extracción ADN y posterior búsqueda de ADN leptospiral.

\subsection{Diseño experimental}

Los animales fueron divididos en 4 grupos iguales. (a) inoculados ip con 0,5 $\mathrm{ml}$ de PBS / 10 ${ }^{7}$ bacterias. (b) Igual que (a) pero administrándole ip $0,30 \mathrm{mg} / \mathrm{kg}$ de peso de 4-aminopiridina (4-AP) diariamente; (c) inoculados ip con 0,5 $\mathrm{ml}$ de PBS; y (d) como (c) con 4-AP como en (b). Grupo de 3 animales fueron sacrificados al 6-7 pi (hámsters) o de 5 animales 14 (ratones) dpi o cuando se veían moribundos, y tanto la sangre como sus riñones fueron cosechados. Una parte fue guardada a 70 ㄷ $\mathrm{C}$ para estudios posteriores y otra fijada en solución de paraformaldehído $4 \%$ para exámenes histológicos y para tinción con inmunoperoxidasa. La efectividad del tratamiento con 4-AP fue confirmada por dosaje de los niveles de nitrato/nitrito séricos por reacción de Griess ya descripta (Gomez et al., 2003a).

\subsection{Selección in sílico de LIC12690, LIC11207, LIC12922 y comparación con otras adhesinas leptospirales}

Las secuencias codificantes de LIC12690, LIC11207 y LIC12922 fueron seleccionadas de la secuencia genómica (Nascimento et al., 2004b) de $L$. interrogans serovar Copenhageni y su localización celular fue predicha con el programa PSORT (Nakai and Horton, 1999; Nakai and Kanehisa, 1991b) y P- 
Classifier (Wang et al., 2005). Los programas SMART (Letunic et al., 2006; Schultz et al., 1998), PFAM (Finn et al., 2006) fueron usados para la búsqueda predictiva de dominios funcionales y estructurales de las secuencias elegidas. Los servidores SignalP y LipoP (Emanuelsson et al., 2007; Juncker et al., 2003) fueron empleados para la determinación del péptido señal y para la predicción de la secuencia del lipobox se usó el programa SpLip (Setubal et al., 2006). El análisis de las secuencias se realizó con el programa ClustalX (Thompson et al., 1997) y Mega5 (Tamura et al., 2011) haciendo uso del método de Neibhbour-Joining (Perriere and Thioulouse, 1996)(Tabla 5.2).

Tabla 5.2 Programas empleados para el análisis bioinformático de las proteínas recombinantes

\begin{tabular}{|c|c|c|}
\hline PROGRAMA & URL & FINALIDAD \\
\hline PSORT & http://www.psort.org/psortb/ & $\begin{array}{c}\text { Localización } \\
\text { Celular }\end{array}$ \\
\hline DAS & http://www.sbc.su.se/ miklos/DAS/ & Dominios \\
\hline TMpred & http://www.ch.embnet.org/software/TMPRED_form.html & Transmembrana \\
\hline P-Classifier & http://protein.bii.astar.edu.sg/localization/gramnegative/index.html. & Dominios \\
\hline The SMART & http://smart.embl-heidelbergde & funcionales \\
\hline PFAM & http://www.sanger.ac.uk/Software/Pfam & y estructurales \\
\hline LipoP & http://www.cbs.dtu.dk/services/LipoP & Péptido señal \\
\hline SignalP & http://www.cbs.dtu.dk/services/SignalP/ & Péptido señal \\
\hline Splip & http://jcslab.vbi.vt.edu/splip/ & lipobox \\
\hline ClustalX & http://www.clustal.org/ & Análisis de \\
\hline MEGA & http://www.megasoftware.net/ & Secuencias \\
\hline
\end{tabular}




\subsection{Aislamiento de ADN genómico}

Para el aislamiento del ADN genómico de las distintas especies de Leptospira, se hirvieron $5 \mathrm{ml}$ de cada cultivo durante 30 minutos y luego los mismos se centrifugaron a 7500 x g durante 30 minutos. Los pellets fueron resuspendidos en $500 \mu \mathrm{l}$ de buffer de lisis (Tris pH: 8, 50 mM; EDTA $1 \mu \mathrm{M}$, TritónX100 1\%, tween 20 0,5\%; SDS 1\%) con el agregado de Proteinasa K (PK, $2 \mu \mathrm{g} / \mathrm{ml}$ ) e incubados 18 horas a 37으 en baño de agua. Se realizaron 2 extracciones con 1 volumen de fenol pH: 8, centrifugándose 15 minutos a 12000 x g, conservando siempre la fase acuosa. Posteriormente se realizaron 4 extracciones con $300 \mu \mathrm{l}$ de cloroformo-alcohol isoamílico, centrifugando en las mismas condiciones. Por último se agregó etanol absoluto y acetato de sodio 0,3 $\mathrm{mM}$ y se incubó 18 horas a -20ㄷ. Se centrifugó a 12000 x g, se secó el pellet en baño a 60 ㄷ C durante 10 minutos y se resuspendió el mismo en $50 \mu$ de buffer TE (Tris- $\mathrm{HCl}$ 10mM, $E D T A \bullet \mathrm{Na}_{2}$. $1 \mathrm{mM}$ pH: 7.9-8.1). El ADN total de riñón fue extraído por homogenización mecánica del mismo en $500 \mu \mathrm{l}$ de buffer de lisis y siguiendo el mismo protocolo descripto anteriormente.

\subsection{Reacción en cadena de la polimerasa (PCR)}

Las PCRs fueron realizadas usando un volumen de reacción de $20 \mu \mathrm{l}$ con 100 ng de ADN genómico, PCR buffer (20 mM Tris- $\mathrm{HCl}$, pH: 8.4, $50 \mathrm{mM} \mathrm{KCl),} \mathrm{1,5}$ $\mathrm{mM} \mathrm{MgCl} 2$, primers 0,5 $\mu \mathrm{M}, 200 \mathrm{mM}$ de cada dNTP, y $2.5 \mathrm{U}$ Taq ADN Polimerasa (PB-L). Los primers empleados se listan en la Tabla $\mathbf{5 . 3}$

Las condiciones de ciclado fueron: 1 ciclo inicial de 2 minutos a 94우 35 ciclos de 20 segundos a $94^{\circ} \mathrm{C}$, 20 segundos a 55으, un tiempo de extensión variable a $72 \circ \mathrm{C}$ y un ciclo final de 2 minutos a $72 \circ \mathrm{C}$. El tiempo de extensión empleado en cada reacción dependió del tamaño del fragmento amplificado, teniendo en cuenta que la Taq polimerasa extiende 1000 pares de base por 
minuto. Los productos de la reacción fueron analizados mediante electroforesis en gel de agarosa. Las concentraciones de agarosa fueron entre 1-2\%, dependiendo del tamaño del amplicón. Las muestras fueron sembradas en buffer de corrida (azul de bromofenol $0,25 \%$ y sacarosa $40 \% \mathrm{p} / \mathrm{v}$ en agua). La electroforesis fue realizada en buffer TAE (Tris.acetato $40 \mathrm{mM}$, EDTA $1 \mathrm{mM}$ ) con 1\% de bromuro de etidio. El voltaje así como el tiempo de corrida dependió de la muestra, el gel y la finalidad de la corrida. La migración de las bandas se observó en un transiluminador de luz UV.

Tabla 5.3 Características de los primers empleadas para los ensayos de PCR.

\begin{tabular}{|c|c|c|c|}
\hline Gen & Primer & Secuencia del primer empleado $\left(5^{\prime}-3^{\prime}\right)$ & Longitud (pb) \\
\hline \multirow[t]{2}{*}{ ARNr16S } & LEPTO Fw & CATTCATGTTTCGAATCATTTCAAA & 331 \\
\hline & LEPTO Rv & GGCCCAAGTTCCTTCTAAAAG & \\
\hline ARNr16S & LEPTO Fw & CAAGTCAAGCGGAGTAGCAATACTCAGC & 1042 \\
\hline (transcripto) & LEPTO Rv & GATGGCAACATAAGGTGAGGGTTGC & \\
\hline \multirow[t]{2}{*}{ lic12690 } & LIC12690 Fw & САCCTTTTCTAACTTCGCGGACTC & 339 \\
\hline & LIC12690 Rv & GTATAAGTTCCTGGAGACCAATTGAGAG & \\
\hline \multirow[t]{2}{*}{ lic11207 } & LIC11207 Fw & GGCATAATCGTCGCCATCTC & 855 \\
\hline & LIC11207 Rv & CTTCCCGTTGAACCTTGACC & \\
\hline \multirow[t]{2}{*}{ lic12922 } & LIC12922 Fw & ATGCGGCCGAATCACTCAAC & 880 \\
\hline & LIC12922 Rv & GGTATTTCGGCCCTGGATTC & \\
\hline \multirow[t]{2}{*}{$\beta$-Actina } & A1 & AACCCCAAGGCCAACCGCGAGAAGATGACC & $412 / 450$ \\
\hline & $\mathrm{A} 2$ & GGTGATGACCTGGCCGTCAGGCAGCTCGTA & \\
\hline \multirow[t]{2}{*}{ iNOS } & iNOS Fw & TGGGAATGGAGACTGTCCCAG & 306 \\
\hline & iNOS Rev & GGGATCTGAATGTGATGTTTG & \\
\hline
\end{tabular}




\subsection{Aislamiento de ARN y RT-PCR}

Para el aislamiento del ARN de las distintas especies de Leptospira, se hirvieron $5 \mathrm{ml}$ de cada cultivo durante 30 minutos y luego los mismos se centrifugaron a 7500 x g durante 30 minutos. Los pellets fueron resuspendidos en $500 \mu \mathrm{l}$ de Trizol y se siguió el protocolo del fabricante. El ARN total fue extraído desde riñón de igual modo previa homogeinización mecánica en Trizol. El tratamiento con DNasa fue llevado a cabo con el RNase-free DNase Kit (Qiagen). EL ADNc fue sintetizado usando 500 ng de ARN, random hexámeros y transcriptasa reversa SuperScript III, de acuerdo con las instrucciones del fabricante. Para el análisis por PCR se usaron las mismas condiciones de ciclado y la misma mix descripta en el inciso 5.10. Los primers empleados se listan en la Tabla 5.3.

\subsection{Curvas de calibración para cuantificación de leptospiras por qPCR}

Como es sabido, en un análisis por PCR en tiempo real (qPCR), es posible medir la cantidad de producto amplificado en cualquier momento. El ciclo a partir del cual la señal de fluorescencia generada por la muestra es mayor a la del background de fluorescencia, denominado Ct (del inglés, cycle threshold), es inversamente proporcional a la cantidad de templado inicial, siendo la base para el cálculo del número de copias. La cuantificación de un producto de PCR a un número de ciclos específico permite comprender de una mejor manera el proceso de PCR con estimaciones verdaderamente cuantitativas. 


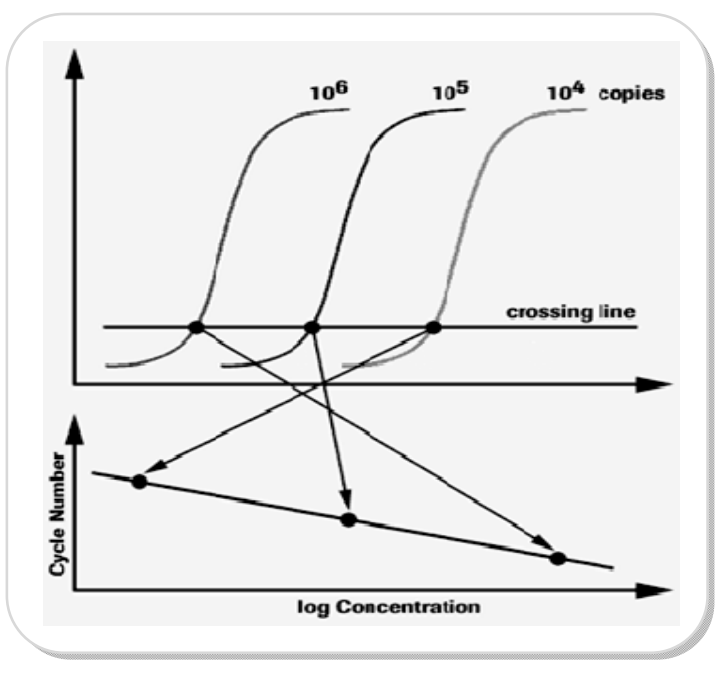

Figura 5.12A Superior: Curva de q-PCR (Fluorescencia vs $N$ de ciclos) para tres muestras de concentración conocida. Inferior: Curva de Calibración (Concentración vs. Ct) construida a partir de los Ct obtenidos en la corrida de qPCR.

En primer lugar se debe elegir un control externo tal como un amplicón clonado, una porción de genoma del organismo target o simplemente el amplicón purificado (Mackay, 2004). El Ct obtenido de la amplificación correspondiente de cada dilución de concentración conocida del control externo, permite construir una curva de calibración necesaria para el análisis de muestras de concentración desconocida tal como se muestra en la Figura 5.12A. Los controles internos tales como muestras de animales, también deberán ser incluidos proveyendo una forma segura de verificar la integridad de todos los pasos de la amplificación. La ausencia de amplificación de los controles internos indican la inhibición del análisis de PCR debido a la muestra obtenida (Cockerill, 2003; Nolte, 2004). EI análisis de la curva de melting constituye un importante control de calidad debido a que confirma la identidad del producto amplificado dado que puede discriminar pares de bases, como por ejemplo mutaciones (Cockerill, 2003; Wittwer et al., 2001). La cuantificación absoluta determina el número exacto de copias target presentes en una muestra relacionando el $\mathrm{Ct}$ obtenido con la curva estándar, facilitando de este modo la comparación de resultados de ensayos diferentes. 


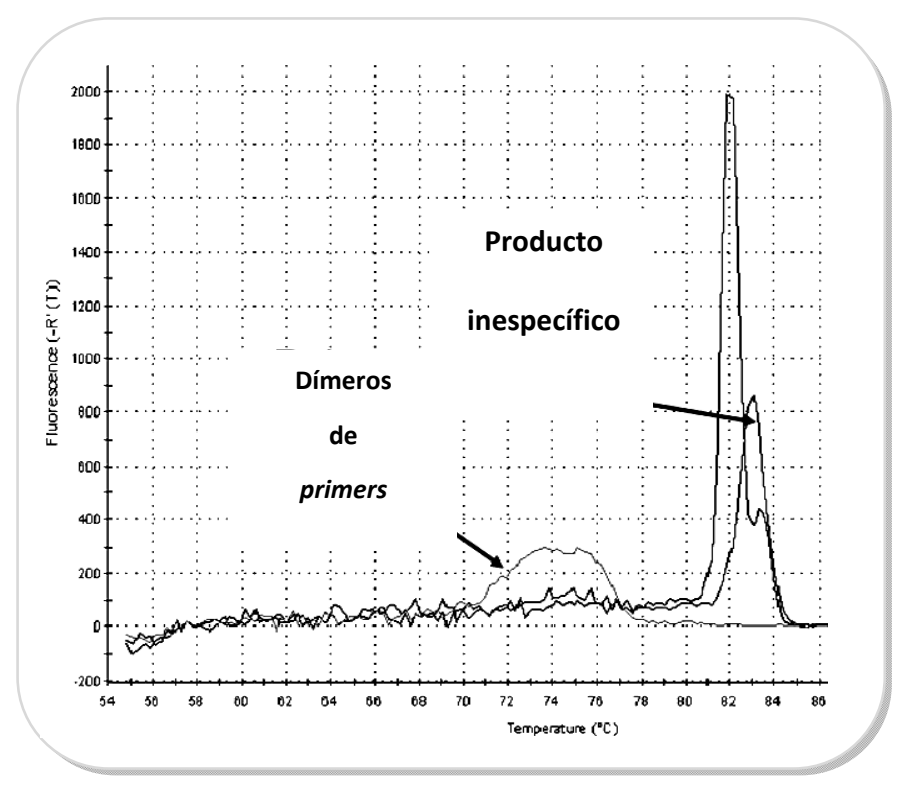

Figura 5.12B Curva de melting de una muestra en la que junto con el producto deseado se amplificó producto inespecífico y dímeros de primers.

Para construir la curva de calibración se amplificó un fragmento de 331pb correspondiente a ARN16S, el cual luego de su purificación habia sido previamente clonado en el vector pGEM-T. La construcción obtenida fue usada para transformar E. Coli DH5a. Se confirmó la presencia de la construcción pGEMT-331 en las colonias obtenidas mediante Colony PCR (Figura 5.13A). Se realizó la extracción y purificación de ADN plasmídico a baja escala (miniprep) usando el método estándar de lisis alcalina (Sambrook et al., 2001). Se cuantificaron las muestras obtenidas espectrofotométricamente y se realizaron diluciones seriadas, las cuales fueron usadas como molde para las reacciones de PCR en tiempo real (Figura 5.13B), permitiendo la construcción de una curva de calibración: № de copias/ $\mu$ l vs Ct (Figura 5.13C). La curva de melting (Figura 5.13D), muestra un pico a 83,8 으 correspondiente al amplicón 331pb-16S demostrando la calidad de la reacción de polimerización. 


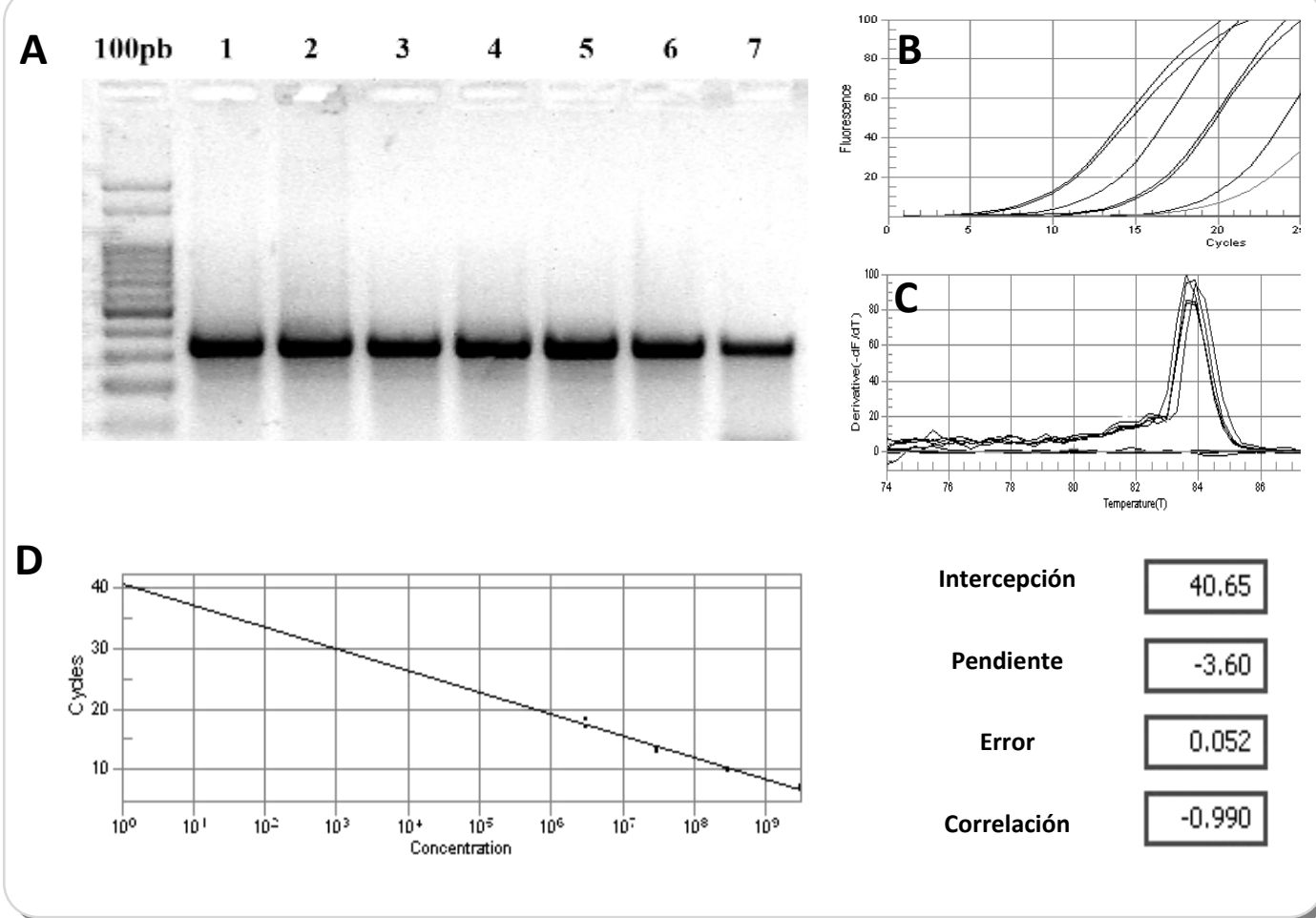

Figura 5.12 Construcción de la curva de calibración para cuantificación de leptospiras spp. A. Colony-PCR de colonias seleccionadas de E. Coli que contenían pGEMT-331pb. B. Corrida de qPCR de las diluciones de concentración conocida de pGEMT-331pb C. Curva de melting. D. Curva de calibración obtenida. Las figuras B, C y D se obtuvieron por medio del software del equipo linegene (Bioer).

Tabla 5.4 Características de los primers y condiciones empleadas para los ensayos de PCR en tiempo real.

\begin{tabular}{|c|c|c|c|c|c|}
\hline Gen & Primer & $\begin{array}{l}\text { Secuencia del primer empleado } \\
\qquad\left(5^{\prime}-3^{\prime}\right)\end{array}$ & $\begin{array}{l}\mathrm{Ta} \\
\left({ }^{\circ} \mathrm{C}\right)\end{array}$ & $\operatorname{Tm}\left({ }^{\circ} \mathrm{C}\right)$ & $\begin{array}{l}\text { Longitud del } \\
\text { amplicón (pb) }\end{array}$ \\
\hline \multirow[t]{2}{*}{ 16S RNA } & LEPTO Fw & CATTCATGTTTCGAATCATTTCAAA & 55 & 80,5 & 331 (ADN) \\
\hline & LEPTO Rv & GGCCCAAGTTCCTTCTAAAAG & & & \\
\hline \multirow[t]{2}{*}{$\beta$-Actina } & $\beta$-Actina Fw & CGACAACGGCTCCGGCATGT & 55 & 84 & $98(A D N)$ \\
\hline & $\beta$-Actina Rv & AGCACCGGCATCGATCCCCA & & & \\
\hline \multirow[t]{2}{*}{ iNOS } & iNOS Fw & CAGCTGGGCTGTACAAAC & 60 & 83 & 95 (ADNc) \\
\hline & iNOS Rev & CATTGGAAGTGAAGCGTTTCG & & & \\
\hline \multirow[t]{2}{*}{$\beta$-Actina } & $\beta$-ACTINA Fw & CGTCATCCATGGCGAACTG & 55 & 83,5 & 60 (ADNc) \\
\hline & $\beta$-ACTINA Rv & GCTTCTTTGCAGCTCCTTCGT & & & \\
\hline
\end{tabular}




\subsection{Curva de calibración de 6-actina transcripto, 6-actina genómico e iNOS}

Se amplificaron los productos deseados con los primers descriptos en la Tabla 5.4. Los tres productos fueron visualizados con luz UV en un gel de agarosa $1,5 \%$ con bromuro de etidio, a partir del cual se cortó la banda deseada y se la purificó con el Wisard SV Gel and PCR Clean-Up System (Promega). Los productos obtenidos de las 3 purificaciones se cuantificaron espectrofotométricamente y se llevaron a la concentración deseada con agua Nucleasa Free (Epicentre) y se realizaron las diluciones seriadas necesarias para la construcción de las 3 curvas de calibración (Figura 5.13).

A

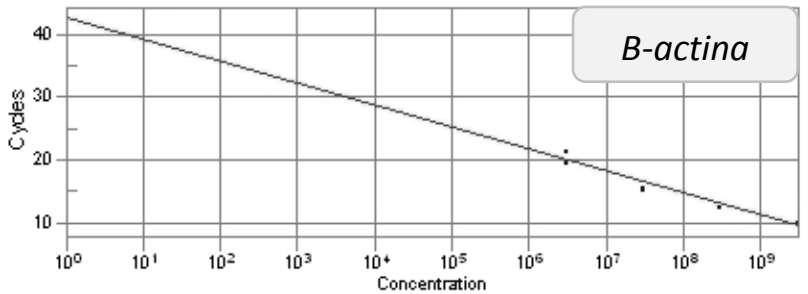

B

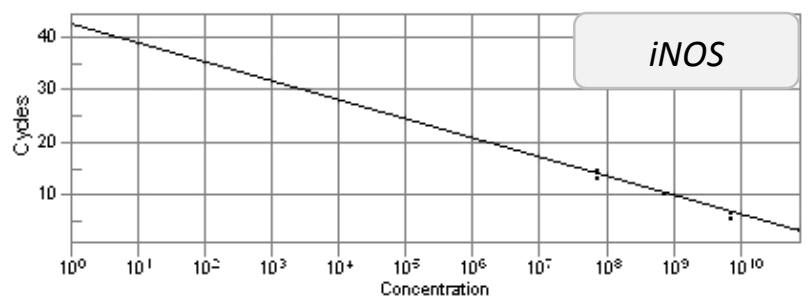

C

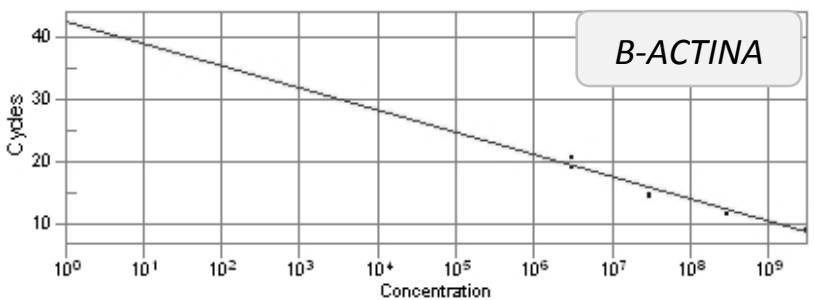

Intercepción

42.32

Pendiente

$-3.51$

Error

0.061

Correlación

$-0.979$

Intercepción

42.26

Pendiente

Error

Correlación

0.070

$-0.991$

Intercepción

42.24

Pendiente

$-3.57$

Error

0.059

Correlación

$-0.982$

Figura 5.13 Construcción de la curvas de calibración para cuantificación de: A. Bactina, ADN. B. iNOS ADNc C. B-actina, ADNc 


\subsection{PCR en tiempo real}

El análisis por PCR en tiempo Real (qPCR) fue realizado con el instrumento Line-Gene FQD-48A (Bioer). Se usó para todas las reacciones la TAQurate green real-time PCR MasterMix (Epicentre Biotechnologies) siguiendo las recomendaciones del fabricante. Inmediatamente después de la amplificación se realizaron las curvas de melting usando un incremento de temperatura de $0,3 \circ \mathrm{C} / \mathrm{s}$ desde los $70 \circ \mathrm{C}$ hasta los $89 \circ \mathrm{C}$ con continua adquisición de fluorescencia. Finalizada la qPCR, el tamaño del amplicón fue confirmado por electroforesis en gel de agarosa. En la Tabla $\mathbf{5 . 4}$ se listan tanto los primers usados para cuantificar (LEPTO) carga bacteriana y para normalizar la cantidad de ADN empleada ( $\beta$ Actina) como los primers usados para cuantificar ADNc de iNOS y normalizar ADNC total ( $\beta$-ACTINA).

\subsection{Expresión y purificación de las proteínas recombinantes}

\subsubsection{Construcciones empleadas}

Se utilizaron las siguientes construcciones: pDEST17-LIC12690, pDEST17LIC11207 y pDEST-LIC12922. El plásmido pDEST17 es un vector comercial (Invitrogen) para expresión y purificación de proteínas recombinantes, el cual posee un origen de replicación multicopia para E. coli. Es un vector de 6354 nucleótidos, que adiciona una cola de 6 histidinas en el extremo amino terminal de la proteína, lo que permite una rápida purificación de la proteína de interés. Este plásmido permite la inserción de fragmentos de ADN bajo un promotor fuerte del bacteriófago T7 que resulta en una alta cantidad de proteína purificada ( $20 \mathrm{mg} / \mathrm{L}$ de cultivo). Este plásmido también posee un gen que codifica para una $\beta$-lactamasa que proporciona resistencia a Amp. La transformación de $E$. coli con plásmidos recombinantes conteniendo Amp permite su selección en medio LB suplementado con ese antibiótico. 


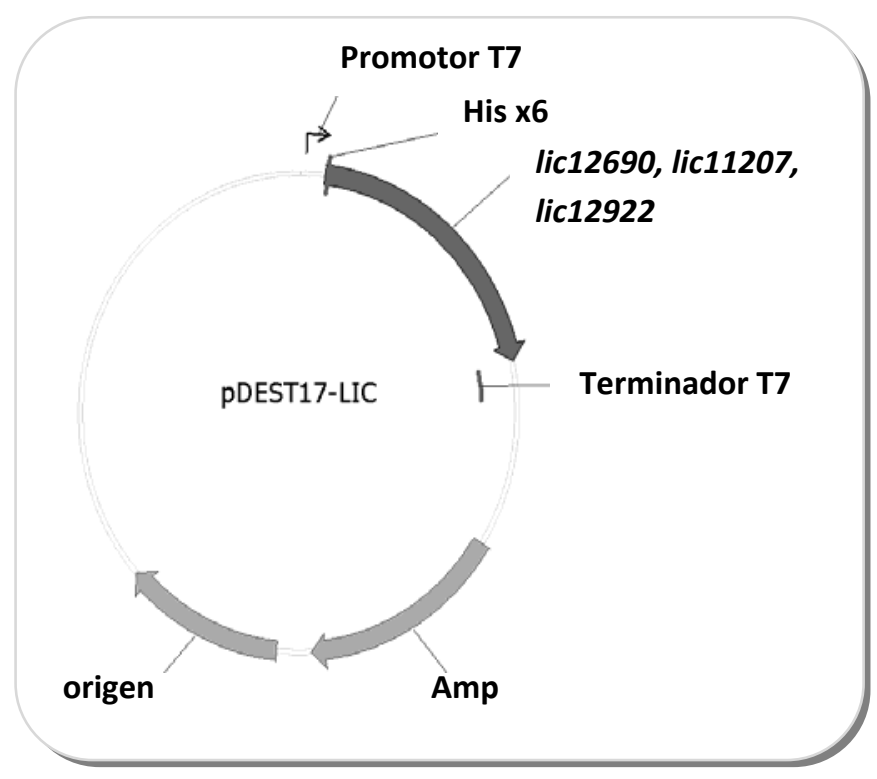

Figura 5.15 Esquema de las construcciones empleadas pDEST17-LICs. Los tamaños de las mismas fueron 8880, 7446, 7443pb para pDEST17-LIC12690/11207/12922, respectivamente.

\subsubsection{Obtención de células competentes}

Se usó una técnica ya descripta (Tung and Chow, 1995) que básicamente consiste en inocular $500 \mathrm{ml}$ de medio LB $\sin \mathrm{NaCl}$ con $1 \mathrm{ml}$ de cultivo saturado, proveniente del stock, incubado overnight a $370 \mathrm{C}$ y con agitación vigorosa. Cuando el cultivo alcanzó una densidad óptica (DO) a $600 \mathrm{~nm}$ de 0.8, las células fueron centrifugadas a 7500 x g durante 15 minutos a 4 으 $\mathrm{y}$ lavadas 2 veces con $200 \mathrm{ml}$ de glicerol $10 \%$ a 4 으. Finalmente se resuspendieron suavemente en $0.5 \mathrm{ml}$ de glicerol $10 \%$ y se guardaron a -80 C hasta su utilización.

\subsubsection{Transformación}

La transformación fue realizada mediante electroporación. Se mezclaron las células competentes recién descongeladas con el ADN a transformar, y se mantuvieron en frío durante aproximadamente 1 minuto. Luego se electroporaron en las condiciones ya descriptas para estas células (2.2 kV; $200 \Omega$; $25 \mu \mathrm{FD}$ ) utilizando un equipo Gene Pulser ${ }^{\mathrm{TM}}$ (Bio-Rad) y cubetas de 0,2 ml. Una vez 
electroporadas, se les agregó medio LB, se incubaron a 37ํㅡ con una agitación de 180 rpm durante 1 hora para permitir la expresión del fenotipo de resistencia. Pasado ese tiempo, se sembraron en medio sólido de LB con Amp, y se incubaron a $370 \mathrm{C}$ aproximadamente $16-18$ horas.

En cada caso se hicieron los siguientes controles: a) control negativo para ver si el sistema estaba contaminado, donde el ADN fue reemplazado por $\mathrm{H}_{2} \mathrm{O}$; b) control positivo donde se electroporó un plásmido cuantificado (DO: $286 \mathrm{~nm}$ ) para determinar la eficiencia de transformación.

\subsubsection{Colony-PCR}

Para identificar los clones positivos que contenían el vector con el inserto, se procedió a picar con un palillo las colonias transformadas y crecidas con medio selectivo. Estas se resuspendieron en $\mathrm{H}_{2} \mathrm{O}$, se hirvieron durante 10 minutos para romper las bacterias, y se centrifugaron para obtener solo la parte soluble y eso se utilizó como molde de ADN para realizar una PCR con primers que flanqueaban el inserto. Al mismo tiempo se realizaron las estrías correspondientes en LB sólido con Amp, para su posterior identificación. Las colonias positivas se usaron como inóculo de $5 \mathrm{ml}$ de LB y se incubaron a $37^{\circ} \mathrm{C}$ con agitación. Luego de 18 horas se guardaron a -80 ㅇ $500 \mu \mathrm{l}$ de cada cultivo en glicerol $30 \%$. El resto del cultivo se centrifugó y se usó para extracción y purificación de ADN plasmídico a baja escala (miniprep) usando el método de lisis alcalina descripto en el protocolo estándar (Sambrook et al., 2001).

\subsubsection{Digestión por enzimas de restricción}

Las minipreps de ADN obtenidas fueron digeridas para corroborar la presencia del inserto. Las digestiones se realizaron con la enzima Xbal (Promega) 
en las condiciones óptimas para la enzima siguiendo las indicaciones del fabricante. La concentración de los fragmentos de ADN, se estimó, en forma aproximada, por la intensidad de fluorescencia producida después de la electroforesis en gel comparando el gel con los fragmentos presentes en el patrón de pesos moleculares de concentración conocida. La inactivación de las enzimas se llevó a cabo según indica el protocolo del fabricante. El producto digerido y sin digerir se sembró en un gel de agarosa y se determinó cuales de las minipreps obtenidas contenían la construcción deseada por análisis en electroforesis.

\subsubsection{Expresión}

Para la expresión de las proteínas recombinantes se usaron células $E$. coli BL21 (SI); en éstas la acción de la T7 ARN polimerasa se encuentra bajo el control del promotor proU que es osmóticamente inducible. Estas células fueron transformadas con pDEST17-LIC11207, pDEST17-LIC12690, pDEST17-LIC12922 y seleccionadas como se describió anteriormente (colony-PCR y miniprepdigestión), e incubadas durante 16 horas en medio LB a $37^{\circ} \mathrm{C}$ con $100 \mathrm{mg} / \mathrm{ml}$ de Amp.

Cuando el cultivo llegó a una DO de 0,8, se realizó una dilución 1:50 del mismo para que en el momento de la inducción todas las bacterias estuvieran en fase exponencial de crecimiento y además diluir las eventuales $\beta$-lactamasas solubles secretadas al medio que pueden apantallar el crecimiento del fenotipo sin resistencia. El crecimiento fue monitoreado por espectrofotometría $(\lambda=600 \mathrm{~nm})$ cada 20-30 minutos. Cuando la DO a $600 \mathrm{~nm}$ fue de 0,6-0,8 se indujo la expresión de las proteínas recombinantes mediante la incorporación de $\mathrm{NaCl} 300$ mM.

Se tomaron muestras a tiempo cero y luego de tres horas de inducción. En paralelo se realizó un control sin inducir del cual también se tomaron las mismas muestras. Estas muestras $(1 \mathrm{ml})$ fueron analizadas mediante electroforesis en geles 
de poliacrilamida. Para ello se centrifugaron durante 2 minutos a 12000 x g, el pellet fue resuspendido en $100 \mu \mathrm{l}$ de $\mathrm{H}_{2} \mathrm{O}$ destilada por vortex, se les agregó $100 \mu \mathrm{l}$ de buffer de corrida (Tris-Cl 100mM (pH 6.8), DTT 200 mM, SDS 4\%, azul de bromofenol $0.2 \%$ y glicerol $20 \%$ ) y luego fueron hervidas durante 10 minutos.

Los cultivos inducidos $(400 \mathrm{ml})$ fueron centrifugados a $10410 \times \mathrm{g}$ durante 20 minutos a 4 으 y resuspendidos en $3 \mathrm{ml}$ de PBS. Luego se les agregó $100 \mathrm{mg} / \mathrm{ml}$ de lisozima y luego de 30 minutos se sonicaron (Ultrasonic Processor; GE Healthcare). Luego se centrifugaron durante 20 minutos a $7500 \times \mathrm{g}$ a 4 으. El pellet fue

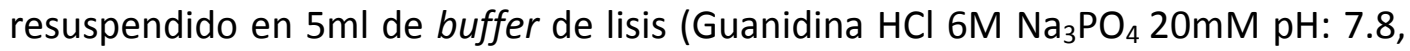
$\mathrm{NaCl} 500 \mathrm{mM}$ ). Se tomaron $20 \mu \mathrm{l}$ del sobrenadante obtenido y del pellet resuspendido y se les agregó $20 \mu \mathrm{l}$ de buffer de corrida a cada uno. Las muestras se hirvieron 10 minutos y se sembraron en un gel de poliacrilamida $12 \%$ a fin de determinar si la proteína recombinante se expresaba de manera soluble o en cuerpos de inclusión.

\subsubsection{Purificación y renaturalización}

Las proteínas fueron purificadas por cromatografía de afinidad metálica utilizando una columna de flujo rápido la cual contenía partículas cargadas con $\mathrm{Ni}^{++}$(GE Healthcare). Brevemente, la columna se equilibró con el buffer de unión (urea $8 \mathrm{M}, \mathrm{Na}_{3} \mathrm{PO}_{4} 20 \mathrm{mM}$ pH: 7.8, NaCl $500 \mathrm{mM}$ ). Las fracciones obtenidas (cuerpos de inclusión resuspendidos en PBS) se pasaron por las respectivas columnas y las proteínas se unieron a las mismas por medio de la interacción de las histidinas con el $\mathrm{Ni}^{++}$. Luego de 1 hora a temperatura ambiente y en agitación suave se centrifugó a baja velocidad $(800 \times$ g) y cuidadosamente se aspiró el sobrenadante. Posteriormente se realizaron 2 lavados con solución de urea 8M, $\mathrm{Na}_{3} \mathrm{PO}_{4} 20 \mathrm{mM}$ pH: 6,0, $\mathrm{NaCl} 500 \mathrm{mM}$ y luego otros dos con la misma solución pero a $\mathrm{pH}: 5,3$. Por último, se eluyó las proteínas de la columna con $5 \mathrm{ml}$ de urea 
$8 \mathrm{M}, \mathrm{Na}_{3} \mathrm{PO}_{4} 20 \mathrm{mM} \mathrm{pH}: 4,0, \mathrm{NaCl} 500$ mM. A continuación, las fracciones obtenidas fueron analizadas por SDS-PAGE 12-15\%.

La renaturalización de las proteínas se realizó por el método de dilución el cual consiste en resuspender las eluciones obtenidas en $2 \mathrm{~L}$ de buffer de refolding (Tris- $\mathrm{HCl} 20$ mM, NaCl 500 mM e imidazol 5 mM). El contenido de LPS se midió por el ensayo cromogénico de LAL usando el QCL-1000 kit (Bio-Whittaker Inc., Walkersville, MD), de acuerdo a las instrucciones del fabricante. El correcto plegado de las proteínas recombinantes fue verificado por dicroísmo circular como se ha descripto (Gomez et al., 2008) en colaboración con la Dra. ALTO Nascimento quien generosamente también proveyó la proteína r12906 utilizada como control en los experimentos de activación endotelial por su alto contenido de LPS y su falta de efecto en la activación de las HUVEC.

\subsection{Producción de antisuero contra las proteínas recombinantes}

Se inmunizaron subcutáneamente hembras Balb/c de 6-8 semanas de edad, en grupos de 5 con aproximadamente 5-15 $\mu$ g de cada proteína recombinante formulada con adyuvante de Freund completo (Vieira et al., 2007). Luego de 21 días, los ratones recibieron nuevas inmunizaciones con proteínas formuladas con adyuvante de Freund incompleto. Después de 2-3 semanas de la última inoculación los animales fueron sangrados y los sueros titulados por ELISA. Como controles se utilizaron sueros de un grupo inoculado con una muestra procesada en forma idéntica excepto que las células fueron transformadas con un vector vacío. 


\subsection{Titulación de los antisueros obtenidos}

El análisis de la especificidad del título de los sueros contra las proteínas recombinantes fue monitoreado por ELISA. Las placas de ELISA fueron sensibilizadas con las proteínas de interés en una concentración aproximada de $0.5 \mu \mathrm{g}$ de proteína en buffer carbonato $\left(\mathrm{Na}_{2} \mathrm{CO}_{3} / \mathrm{HNaCO}_{3} 0,05 \mathrm{M}, \mathrm{pH}: 9,6\right)$ en un volumen final de $100 \mu \mathrm{l} /$ well por aproximadamente 14 horas a 4 으. Luego de 5 lavados con PBS/Tween20 0,05 \%, se bloqueó la unión inespecífica con $200 \mu \mathrm{l} /$ well de una solución de PBS/Tween 0,05\%/leche descremada 5\% (solución de bloqueo), por 2 horas en estufa a 37으. A continuación se hicieron 5 lavados con PBS/Tween20 0,05\% y se incubó con $100 \mu \mathrm{l} /$ well de diluciones seriadas del antisuero en solución de bloqueo durante 1 hora en estufa a $37^{\circ} \mathrm{C}$. Nuevamente se realizaron 5 lavados y se agregó $100 \mu \mathrm{l} /$ well de antisuero anti-lgG especie específico conjugado con peroxidasa (anti-ratón Dako) en una dilución de 1:2000, en solución de bloqueo y se incubó por 1 hora en estufa a 37으. Se hicieron 5 lavados y se adicionó $100 \mu \mathrm{l} /$ well de la solución OPD (o-phenilenediamine) 0,4 $\mathrm{mg} / \mathrm{ml}$ en buffer fosfato-citrato $0,05 \mathrm{M}, \mathrm{pH}: 5.0$ conteniendo $\mathrm{H}_{2} \mathrm{O}_{2}(10 \mu \mathrm{l}$ de solución 30\% para un volumen de $20 \mathrm{ml}$ de substrato). La reacción fue interrumpida con $50 \mu \mathrm{l} /$ well de la solución $\mathrm{H}_{2} \mathrm{SO}_{4} 2 \mathrm{M}$ y la absorbancia fue leída a $492 \mathrm{~nm}$ en lector de microplacas (Labsystems).

\subsection{Inmunohistoquímica}

Con el fin de detectar la presencia de Lp95, LIC11207, LIC12922 e iNOS en tejidos de riñón, se inocularon en forma intraperitoneal 3 hámsters de 180 gr con $0.5 \mathrm{ml}$ de PBS $(\mathrm{pH} 7,2)$ conteniendo $10^{2}$ bacterias (LIC). A las 2 semanas pi, cuando los animales presentaban síntomas tales como letargia, fueron sacrificados. Los riñones fueron cosechados y procesados para histología de la manera habitual. Como controles se usaron 3 animales inoculados con PBS. 
El procedimiento ha sido previamente descripto (Gomez et al., 2008). Brevemente, luego de la rehidratación, secciones de tejido en vidrios Pro-Bond Plus fueron calentadas 3 veces durante 5 minutos en buffer citrato $10 \mathrm{mM}$ en horno microondas. Las secciones fueron enfriadas e inmersas en $\mathrm{H}_{2} \mathrm{O}_{2} 3 \%$ durante 15 minutos a fin de inhibir la actividad de la peroxidada endógena. Para bloquear los sitios de pegado inespecíficos, las secciones fueron incubadas en suero normal de cabra $5 \%$ en PBS durante 20 minutos a temperatura ambiente. Los tejidos fueron incubados con los respectivos sueros policlonales de ratón descriptos en la sección 5.16 en una dilución 1:100 por 1 hora a TA, con suero de ratón anti-LIC (Gamberini et al., 2005), como control positivo o con anticuerpo policlonal antiiNOS (Cayman USA) durante 1 hora a temperatura ambiente. Luego de varios lavados con PBS, se incubó con el anticuerpo secundario (Inmunoglobulina antiratón en cabra) conjugado a un polímero de dextrán unido a peroxidada (DAKO, En vision) durante 20 minutos a temperatura ambiente. Luego de realizar varios lavados con PBS se agregó diaminobencidina/ $\mathrm{H}_{2} \mathrm{O}_{2}(D A B)$, cromógeno y sustrato de la peroxidasa, respectivamente. Luego de 10 minutos cuando el preparado alcanzó una intensidad indicada se agregó agua destilada para detener la reacción de tinción. Las secciones inmunoteñidas fueron contrateñidas con hematoxilina durante 1 minuto, lavadas con agua corriente, luego agua destilada y deshidratada con concentraciones crecientes de etanol seguido de xileno (cada tratamiento de 5 minutos). Finalmente, las secciones se montaron sobre un cubreobjetos en un medio de montaje permanente no-acuoso y fueron observadas en un microscopio Nikon E200.

\subsection{Análisis de reactividad entre suero de pacientes y las proteínas recombinantes}

El análisis se llevó a cabo por medio de la técnica ELISA tal como se describió en el punto 5.17, con la diferencia que los antisueros empleados 
correspondieron a pacientes sanos y convalecientes y como anticuerpo secundario se usó IgG anti-humano (Sigma) en una dilución 1:2000.

\subsection{Respuesta humoral en animales infectados tratados y sin tratar con 4-AP}

El análisis se llevó a cabo por medio de la técnica ELISA tal como se describió en el punto 5.17, con algunas modificaciones. Las placas fueron cubiertas con $10^{6}$ LIC inactivadas por calor por well. Las muestras de suero fueron diluidas 1:20 y se evaluó IgG e IgM total usando anticuerpos de conejo antihámster o anti-ratón conjugado a HRP (1:5000, Sigma), y en el primer caso como anticuerpo secundario anticuerpo de cabra anti-conejo conjugados a HRP (1:5000; Sigma).

\subsection{Immunoblotting}

Este fue realizado esencialmente como se describió previamente (Pacienza et al., 2008). Brevemente, luego de la transferencia la membrana fue bloqueada durante toda la noche con solución de bloqueo (PBS/Tween 20 0,05\%/leche en polvo descremada 5\%). Se realizaron 3 lavados con PBS-Tween (PBS-T) y se incubó con anti-iNOS (1:1000X) o anti-actina (1:1000X), respectivamente, en solución de bloqueo, 1 hora a 37으. Luego de 3 lavados con PBS-T la membrana fue incubada con IgG conjugada a HRP anti-conejo o anti-ratón (1:5000) en solución de bloqueo 1 hora a $37{ }^{\circ} \mathrm{C}$, respectivamente. Las bandas fueron reveladas con ECL (GE Healthcare) siguiendo las instrucciones del fabricante. 


\subsection{Caracterización de la actividad biológica de las proteínas recombinantes sobre las células endoteliales}

Las células endoteliales aisladas de la vena umbilical humana (HUVEC) se obtuvieron de acuerdo a como se ha descripto previamente (Gomez et al., 2008), con mínimas variaciones. Las células fueron sembradas en frascos de $25 \mathrm{~cm}^{2}$ recubiertos con $1 \%(\mathrm{p} / \mathrm{v})$ de gelatina e identificadas por morfología y por marcación con un anticuerpo anti Factor von Willebrand (VWF) (Immunotech, France) en análisis por citometría de flujo. Las células fueron crecidas en medio RPMI 1640 (HyClone, USA) tal como se describe en la sección 5.2, e incubadas a $37^{\circ} \mathrm{C}$ en una atmósfera humidificada con $5 \%$ de $\mathrm{CO}_{2}$. Una vez alcanzada la confluencia, las células fueron despegadas con un tratamiento suave de tripsinaEDTA $\left(0.05 \%\right.$ y $0.1 \mathrm{mM}$, respectivamente), lavadas con PBS (sin $\mathrm{Ca}^{2+}$ y $\mathrm{Mg}^{2+}$ ) suplementado con $10 \%$ de FBS y finalmente sembradas en placas de 96 wells. Las HUVEC fueron usadas entre los pasajes 1-3. Los experimentos fueron realizados en presencia de polimixina $B(P M B, 7 \mu g / m l)$ (Sigma) para descartar posibles efectos asociados a LPS bacterianos.

Las HUVEC fueron expuestas durante 1 hora a $25 \mu \mathrm{g}$ de cada proteína recombinante. Luego se lavó la monocapa y se restituyó el medio RPMI con 10\% de FBS. Luego de 1, 4 o 16 horas se evaluaron los niveles de vWF en los sobrenadantes, y de E-selectina o ICAM-1 en las células, respectivamente. Las células fueron tripsinadas, centrifugadas y resuspendidas en PBS/FBS conteniendo concentraciones saturantes de anticuerpos monoclonales (mAbs), ICAM-1 O Eselectina (Pharmigen) conjugados con FITC. Como control de unión no específica, los mAbs conjugados con FITC fueron reemplazados con mAbs isotípicos irrelevantes. Luego del marcado, las células fueron lavadas, fijadas con $1 \%$ de paraformaldehido y analizadas por citometría de flujo. Para saber si la activación

endotelial era inducida únicamente por las proteínas recombinantes y no por el LPS contaminante se trataron $25 \mu \mathrm{g} / \mathrm{ml}$ de las mismas con PK (500 ng/ml), enzima que degrada las proteínas. El tratamiento con PK se llevó a cabo también con 
factor de necrosis tumoral alfa (TNF- $\alpha, 10 \mathrm{ng} / \mathrm{ml}$ ), incluido en el experimento como control positivo y susceptible a la acción de la PK y con LPS $(1 \mu \mathrm{g} / \mathrm{ml})$ el cual induce la expresión de ICAM-1 y de E-selectina y no se ve afectado por el agregado de PK. Para evaluar el efecto sobre la expresión endotelial de E-Selectina y de ICAM-1 que produce el tratamiento de HUVEC con cepas patogénicas y no patogénicas se procedió del mismo modo que fue descripto anteriormente pero realizando la incubación durante 1 hora con $100 \mu$ de leptospiras $\left(10^{5}\right)$ en EMJH líquido en lugar de emplear las proteínas recombinantes. Las cepas empleadas fueron L. interrogans serovar Copenhagenni y L. biflexa serovar Patoc descriptas previamente. La valoración de los niveles de vWF en los sobrenadantes se realizó empleando un ensayo de ELISA según se ha descripto (Gomez et al., 2003b).

\subsection{Capacidad de las proteínas recombinantes de inhibir la apoptosis}

\subsubsection{Aislamiento de células polimorfonucleares (PMN) humanas}

Los PMN fueron aislados de sangre periférica extraída de un donante voluntario sano que había dado su consentimiento informado por escrito con posterioridad a la aprobación del comité de ética institucional. Los PMNs fueron aislados por gradiente de centrifugación de Ficoll Hypaque $(\delta=1077)$ (Ficoll; BIAcore, Uppsala, Sweden) (Hypaque; Winthrop Products, Buenos Aires, Argentina) y posterior sedimentación con dextrán (Trevani et al., 1999). La suspensiones de células contenían más del 96\% de neutrófilos, determinado por May Grunwald-Giemsa, y los niveles de contaminación de monocitos fueron siempre menores a $0.2 \%$, evaluados por marcación de CD14 y citometría de flujo. Las células fueron resuspendidas en medio RPMI 1640 (Invitrogen, Carlsbad, CA) suplementados con $5 \%$ suero fetal bovino (Invitrogen) en concentración de $2.5 \times 10^{6} / \mathrm{ml}$. 


\subsubsection{Tinción de naranja de acridina y bromuro de etidio para la determinación}

de la viabilidad celular

Los PMN (250000/well) fueron sembrados en una microplaca de 96 wells e incubados con diferentes cantidades de proteínas recombinantes. Luego de 18 horas, las células se marcaron con una mezcla de colorantes fluorescentes que se unen al ADN compuesta por $100 \mu \mathrm{g} / \mathrm{ml}$ de naranja de acridina y $100 \mu \mathrm{g} / \mathrm{ml}$ de bromuro de etidio (Pozner et al., 2005). Los porcentajes de células viables y no viables fueron determinados por microscopía de fluorescencia a través de la observación de los cambios en la morfología y coloración nuclear. El porcentaje de células necróticas nunca superó el $1 \%$.

\subsection{Análisis estadístico}

Todos los resultados fueron expresados como media \pm DS. El estadístico utilizado fue análisis de una-vía de varianza (ANOVA) seguido del procedimiento de múltiple comparación de Newman-Keuls. Los valores de $p<0,05$ fueron considerados estadísticamente significativos. 
Parte de los resultados aquí presentados han sido publicados previamente:

Atzingen, M.V., Gomez, R.M., Schattner, M., Pretre, G., Goncales, A.P., de Morais, Z.M., Vasconcellos, S.A., and Nascimento, A.L. (2009). Lp95, a novel leptospiral protein that binds extracellular matrix components and activates eselectin on endothelial cells. J Infect 59, 264-276.

Pretre, G., Olivera, N., Cedola, M., Haase, S., Alberdi, L., Brihuega, B., and Gomez, R.M. (2011). Role of inducible nitric oxide synthase in the pathogenesis of experimental leptospirosis. Microb Pathog 51, 203-208. 


\section{Referencias}


Abb, J. (2002). Acute leptospirosis in a triathlete. Wilderness Environ Med 13, 45-47.

Abdulkader, R.C., Seguro, A.C., Malheiro, P.S., Burdmann, E.A., and Marcondes, M. (1996). Peculiar electrolytic and hormonal abnormalities in acute renal failure due to leptospirosis. Am J Trop Med Hyg 54, 1-6.

Adler, B., and de la Pena Moctezuma, A. (2010). Leptospira and leptospirosis. Vet Microbiol 140, 287-296.

Adler, B., and Faine, S. (1977). Host immunological mechanisms in the resistance of mice to leptospiral infections. Infect Immun 17, 67-72.

Adu-Bobie, J., Capecchi, B., Serruto, D., Rappuoli, R., and Pizza, M. (2003). Two years into reverse vaccinology. Vaccine 21, 605-610.

Alfonso, H.C., Gomez, O.C., Fonte, L.M., and Quintana, Q.P. (2005). [Isolation of a strain from the Bataviae pathogenic complex in patient vaccinated against copenhageni, canicola and mozdok]. Rev Cubana Med Trop 57, 73-74.

Alston, J.M., and J. C. Broom. (1958). Leptospirosis in man and animals. E\& S Livingstone, Edinburgh, UK.

Andrew, P.J., and Mayer, B. (1999). Enzymatic function of nitric oxide synthases. Cardiovasc Res 43, 521-531.

Arean, V.M. (1962). The pathologic anatomy and pathogenesis of fatal human leptospirosis (Weil's disease). Am J Pathol 40, 393-423.

Arean, V.M., and Henry, J.B. (1964). Studies on the Pathogenesis of Leptospirosis. Iv. The Behavior of Transaminases and Oxidative Enzymes in Experimental Leptospirosis: A Histochemical and Biochemical Assay. Am J Trop Med Hyg 13, 430-442.

Athanazio, D.A., Silva, E.F., Santos, C.S., Rocha, G.M., Vannier-Santos, M.A., McBride, A.J., Ko, A.I., and Reis, M.G. (2008). Rattus norvegicus as a model for persistent renal colonization by pathogenic Leptospira interrogans. Acta Trop 105, 176-180.

Atzingen, M.V., Barbosa, A.S., De Brito, T., Vasconcellos, S.A., de Morais, Z.M., Lima, D.M., Abreu, P.A., and Nascimento, A.L. (2008). Lsa21, a novel leptospiral protein binding adhesive matrix molecules and present during human infection. BMC Microbiol 8, 70.

Atzingen, M.V., Gomez, R.M., Schattner, M., Pretre, G., Goncales, A.P., de Morais, Z.M., Vasconcellos, S.A., and Nascimento, A.L. (2009). Lp95, a novel leptospiral protein that binds extracellular matrix components and activates e-selectin on endothelial cells. J Infect 59, 264-276.

Atzingen, M.V., Goncales, A.P., de Morais, Z.M., Araujo, E.R., De Brito, T., Vasconcellos, S.A., and Nascimento, A.L. (2010). Characterization of leptospiral proteins that afford partial protection in hamsters against lethal challenge with Leptospira interrogans. J Med Microbiol 59, 1005-1015.

Barbosa, A.S., Abreu, P.A., Neves, F.O., Atzingen, M.V., Watanabe, M.M., Vieira, M.L., Morais, Z.M., Vasconcellos, S.A., and Nascimento, A.L. (2006). A newly identified leptospiral adhesin mediates attachment to laminin. Infect Immun 74, 6356-6364.

Barocchi, M.A., Ko, A.I., Ferrer, S.R., Faria, M.T., Reis, M.G., and Riley, L.W. (2001). Identification of new repetitive element in Leptospira interrogans serovar copenhageni and its application to PCR-based differentiation of Leptospira serogroups. J Clin Microbiol 39, 191-195.

Behrens-Kneip, S. (2010). The role of SurA factor in outer membrane protein transport and virulence. Int J Med Microbiol 300, 421-428.

Bharti, A.R., Nally, J.E., Ricaldi, J.N., Matthias, M.A., Diaz, M.M., Lovett, M.A., Levett, P.N., Gilman, R.H., Willig, M.R., Gotuzzo, E., et al. (2003). Leptospirosis: a zoonotic disease of global importance. Lancet Infect Dis 3, 757-771. 
Bitto, E., and McKay, D.B. (2002). Crystallographic structure of SurA, a molecular chaperone that facilitates folding of outer membrane porins. Structure 10, 1489-1498.

Bonventre, J.V. (2007). Pathophysiology of acute kidney injury: roles of potential inhibitors of inflammation. Contrib Nephrol 156, 39-46.

Bourzac, J.F., Rodriguez, S.S., Gonzalez, M.G., Amat, V.P., and Medina, M.F. (2005). [Single-dose toxicological test for leptospirosis vaccine vax-SPIRAL in mice]. Rev Cubana Med Trop 57, 65-66.

Boyle, E.C., and Finlay, B.B. (2003). Bacterial pathogenesis: exploiting cellular adherence. Curr Opin Cell Biol 15, 633-639.

Bremer, V., Tojo, A., Kimura, K., Hirata, Y., Goto, A., Nagamatsu, T., Suzuki, Y., and Omata, M. (1997). Role of nitric oxide in rat nephrotoxic nephritis: comparison between inducible and constitutive nitric oxide synthase. J Am Soc Nephrol 8, 1712-1721.

Bulach, D.M., Zuerner, R.L., Wilson, P., Seemann, T., McGrath, A., Cullen, P.A., Davis, J., Johnson, M., Kuczek, E., Alt, D.P., et al. (2006). Genome reduction in Leptospira borgpetersenii reflects limited transmission potential. Proc Natl Acad Sci U S A 103, 14560-14565.

Bunikis, J., and Barbour, A.G. (1999). Access of antibody or trypsin to an integral outer membrane protein (P66) of Borrelia burgdorferi is hindered by Osp lipoproteins. Infect Immun 67, 2874-2883.

Burth, P., Younes-Ibrahim, M., Goncalez, F.H., Costa, E.R., and Faria, M.V. (1997). Purification and characterization of a $\mathrm{Na}+\mathrm{K}+$ ATPase inhibitor found in an endotoxin of Leptospira interrogans. Infect Immun 65, 1557-1560.

Ciccarelli, F.D., Doerks, T., von Mering, C., Creevey, C.J., Snel, B., and Bork, P. (2006). Toward automatic reconstruction of a highly resolved tree of life. Science 311, 1283-1287. Cockerill, F.R., 3rd (2003). Application of rapid-cycle real-time polymerase chain reaction for diagnostic testing in the clinical microbiology laboratory. Arch Pathol Lab Med 127, 1112-1120.

Cullen, P.A., Lo, M., Bulach, D.M., Cordwell, S.J., and Adler, B. (2003). Construction and evaluation of a plasmid vector for the expression of recombinant lipoproteins in Escherichia coli. Plasmid 49, 18-29.

Curran, R.D., Billiar, T.R., Stuehr, D.J., Ochoa, J.B., Harbrecht, B.G., Flint, S.G., and Simmons, R.L. (1990). Multiple cytokines are required to induce hepatocyte nitric oxide production and inhibit total protein synthesis. Ann Surg 212, 462-469; discussion 470-461. Chassin, C., Picardeau, M., Goujon, J.M., Bourhy, P., Quellard, N., Darche, S., Badell, E., d'Andon, M.F., Winter, N., Lacroix-Lamande, S., et al. (2009). TLR4- and TLR2-mediated B cell responses control the clearance of the bacterial pathogen, Leptospira interrogans. J Immunol 183, 2669-2677.

Chee, H.D., Ossenkoppele, G.J., Bronsveld, W., and Thijs, L.G. (1985). Adult respiratory distress syndrome in leptospira icterohaemorrhagiae infection. Intensive Care Med 11, 254-256.

Chou, D.E., Cai, H., Jayadevappa, D., and Porush, J.G. (2002). Regional expression of inducible nitric oxide synthase in the kidney stimulated by lipopolysaccharide in the rat. Exp Physiol 87, 153-162.

Choy, H.A., Kelley, M.M., Chen, T.L., Moller, A.K., Matsunaga, J., and Haake, D.A. (2007). Physiological osmotic induction of Leptospira interrogans adhesion: LigA and LigB bind extracellular matrix proteins and fibrinogen. Infect Immun 75, 2441-2450. 
Du, C., Guan, Q., Diao, H., Yin, Z., and Jevnikar, A.M. (2006). Nitric oxide induces apoptosis in renal tubular epithelial cells through activation of caspase-8. Am J Physiol Renal Physiol 290, F1044-1054.

Dupont, H., Dupont-Perdrizet, D., Perie, J.L., Zehner-Hansen, S., Jarrige, B., and Daijardin, J.B. (1997). Leptospirosis: prognostic factors associated with mortality. Clin Infect Dis 25, 720-724.

Edwards, C.N., and Levett, P.N. (2004). Prevention and treatment of leptospirosis. Expert Rev Anti Infect Ther 2, 293-298.

Ehlers, M.R., and Daffe, M. (1998). Interactions between Mycobacterium tuberculosis and host cells: are mycobacterial sugars the key? Trends Microbiol 6, 328-335.

Emanuelsson, O., Brunak, S., von Heijne, G., and Nielsen, H. (2007). Locating proteins in the cell using TargetP, SignalP and related tools. Nat Protoc 2, 953-971.

Everard, J.D. (1996). Leptospirosis, p. 111-119, 416-418. In F. E. G. Cox (ed.), The Wellcome Trust illustrated history of tropical diseases. The Wellcome Trust, London, U.K. Faine, S., Adler, B., and eds. (1999). Leptospira and Leptospirosis (Melbourne Australia).

Farghali, H., Canova, N., Gaier, N., Lincova, D., Kmonickova, E., Strestikova, P., and Masek, K. (2002). Inhibition of endotoxemia-induced nitric oxide synthase expression by cyclosporin A enhances hepatocyte injury in rats: amelioration by NO donors. Int Immunopharmacol 2, 117-127.

Farzaneh-Far, R., and Moore, K. (2001). Nitric oxide and the liver. Liver 21, 161-174.

Feigin, R.D., and Anderson, D.C. (1975). Human leptospirosis. CRC Crit Rev Clin Lab Sci 5, 413-467.

Finlay, B.B., and Cossart, P. (1997). Exploitation of mammalian host cell functions by bacterial pathogens. Science 276, 718-725.

Finn, R.D., Mistry, J., Schuster-Bockler, B., Griffiths-Jones, S., Hollich, V., Lassmann, T., Moxon, S., Marshall, M., Khanna, A., Durbin, R., et al. (2006). Pfam: clans, web tools and services. Nucleic Acids Res 34, D247-251.

Fujihara, C.K., Mattar, A.L., Vieira, J.M., Jr., Malheiros, D.M., Noronha Ide, L., Goncalves, A.R., De Nucci, G., and Zatz, R. (2002). Evidence for the existence of two distinct functions for the inducible NO synthase in the rat kidney: effect of aminoguanidine in rats with $5 / 6$ ablation. J Am Soc Nephrol 13, 2278-2287.

Gabbai, F.B., Hammond, T.C., Thomson, S.C., Khang, S., and Kelly, C.J. (2002). Effect of acute iNOS inhibition on glomerular function in tubulointerstitial nephritis. Kidney Int 61, 851-854.

Gamberini, M., Gomez, R.M., Atzingen, M.V., Martins, E.A., Vasconcellos, S.A., Romero, E.C., Leite, L.C., Ho, P.L., and Nascimento, A.L. (2005). Whole-genome analysis of Leptospira interrogans to identify potential vaccine candidates against leptospirosis. FEMS Microbiol Lett 244, 305-313.

Giuseppe, P.O., Von Atzingen, M., Nascimento, A.L., Zanchin, N.I., and Guimaraes, B.G. (2011). The crystal structure of the leptospiral hypothetical protein LIC12922 reveals homology with the periplasmic chaperone SurA. J Struct Biol 173, 312-322.

Goldstein, R.E., Lin, R.C., Langston, C.E., Scrivani, P.V., Erb, H.N., and Barr, S.C. (2006). Influence of infecting serogroup on clinical features of leptospirosis in dogs. J Vet Intern Med 20, 489-494.

Goligorsky, M.S., Brodsky, S.V., and Noiri, E. (2002). Nitric oxide in acute renal failure: NOS versus NOS. Kidney Int 61, 855-861. 
Gómez RM, Romer Y, Seijo A, Habarta A, Cifuente JO, and SA., G. (2007). Expression of oxidative stress related enzymes in experimental leptospirosis. Paper presented at: 5 th Meeting of Internacional Leptospirosis Society (Quito, Ecuador).

Gomez, R.M., Levander, O.A., and Sterin-Borda, L. (2003a). Reduced inotropic heart response in selenium-deficient mice relates with inducible nitric oxide synthase. Am J Physiol Heart Circ Physiol 284, H442-448.

Gomez, R.M., Pozner, R.G., Lazzari, M.A., D'Atri, L.P., Negrotto, S., Chudzinski-Tavassi, A.M., Berria, M.I., and Schattner, M. (2003b). Endothelial cell function alteration after Junin virus infection. Thromb Haemost 90, 326-333.

Gomez, R.M., Vieira, M.L., Schattner, M., Malaver, E., Watanabe, M.M., Barbosa, A.S., Abreu, P.A., de Morais, Z.M., Cifuente, J.O., Atzingen, M.V., et al. (2008). Putative outer membrane proteins of Leptospira interrogans stimulate human umbilical vein endothelial cells (HUVECS) and express during infection. Microb Pathog 45, 315-322.

Gross, S.S., and Wolin, M.S. (1995). Nitric oxide: pathophysiological mechanisms. Annu Rev Physiol 57, 737-769.

Guedes e Silva, J.B., Paiva, L.M., Pereira da Silva, J.J., and de Souza Netto, B.A. (1980). Pathological involvement of human gastrocnemius muscle in leptospirosis (a study in 63 patients). Rev Bras Pesqui Med Biol 13, 9-13.

Haake, D.A., Chao, G., Zuerner, R.L., Barnett, J.K., Barnett, D., Mazel, M., Matsunaga, J., Levett, P.N., and Bolin, C.A. (2000). The leptospiral major outer membrane protein LipL32 is a lipoprotein expressed during mammalian infection. Infect Immun 68, 2276-2285.

Haake, D.A., Mazel, M.K., McCoy, A.M., Milward, F., Chao, G., Matsunaga, J., and Wagar, E.A. (1999). Leptospiral outer membrane proteins OmpL1 and LipL41 exhibit synergistic immunoprotection. Infect Immun 67, 6572-6582.

Hasnain, S.E., and Ahmed, N. (2004). Leptospirosis. Lancet Infect Dis 4, 543; discussion 544.

Hauk, P., Macedo, F., Romero, E.C., Vasconcellos, S.A., de Morais, Z.M., Barbosa, A.S., and Ho, P.L. (2008). In LipL32, the major leptospiral lipoprotein, the $C$ terminus is the primary immunogenic domain and mediates interaction with collagen IV and plasma fibronectin. Infect Immun 76, 2642-2650.

Hayashi, S., and Wu, H.C. (1990). Lipoproteins in bacteria. J Bioenerg Biomembr 22, 451471.

Heisey, G.B., Nimmanitya, S., Karnchanachetanee, C., Tingpalapong, M., Samransamruajkit, S., Hansukjariya, P., Elwell, M.R., and Ward, G.S. (1988). Epidemiology and characterization of leptospirosis at an urban and provincial site in Thailand. Southeast Asian J Trop Med Public Health 19, 317-322.

Heron, L.G., Reiss-Levy, E.A., Jacques, T.C., Dickeson, D.J., Smythe, L.D., and Sorrell, T.C. (1997). Leptospirosis presenting as a haemorrhagic fever in a traveller from Africa. Med J Aust 167, 477-479.

Hersh, D., Monack, D.M., Smith, M.R., Ghori, N., Falkow, S., and Zychlinsky, A. (1999). The Salmonella invasin SipB induces macrophage apoptosis by binding to caspase-1. Proc Natl Acad Sci U S A 96, 2396-2401.

Hilbi, H., Moss, J.E., Hersh, D., Chen, Y., Arondel, J., Banerjee, S., Flavell, R.A., Yuan, J., Sansonetti, P.J., and Zychlinsky, A. (1998). Shigella-induced apoptosis is dependent on caspase-1 which binds to IpaB. J Biol Chem 273, 32895-32900.

Ho, K.J., and Scully, K.T. (1980). Acute rhabdomyolysis and renal failure in Weil's disease. Ala J Med Sci 17, 133-137. 
Hoke, D.E., Egan, S., Cullen, P.A., and Adler, B. (2008). LipL32 is an extracellular matrixinteracting protein of Leptospira spp. and Pseudoalteromonas tunicata. Infect Immun 76, 2063-2069.

lagovkin, E.A., Kostina, N.I., Vachaev, B.F., Romantsova, T.P., Kondratenko, V.F., Bunin, I.E., Gol'denshtein, Z.A., and Anan'ina lu, V. (1990). [The improvement of immunobiological preparations against leptospirosis. An experimental study of a new concentrated purified vaccine against icterohemorrhagic leptospirosis for human immunization]. Zh Mikrobiol Epidemiol Immunobiol, 47-51.

Ido, Y., R. Hoki, H. Ito, and H. Wani. (1917). The rat as a carrier of Spirochaeta icterohaemorrhagiae, the causative agent of Weil's disease (spirochaetosis icterohaemorrhagica). J Exp Med 26, 341-353.

Johnson, R.C., and Faine, S., eds. (1984). Leptospira, (Baltimore, Md., Williams\& Wilkins).

Juncker, A.S., Willenbrock, H., Von Heijne, G., Brunak, S., Nielsen, H., and Krogh, A. (2003). Prediction of lipoprotein signal peptides in Gram-negative bacteria. Protein Sci 12, 16521662.

Kan, W., Zhao, K.S., Jiang, Y., Yan, W., Huang, Q., Wang, J., Qin, Q., Huang, X., and Wang, S. (2004). Lung, spleen, and kidney are the major places for inducible nitric oxide synthase expression in endotoxic shock: role of p38 mitogen-activated protein kinase in signal transduction of inducible nitric oxide synthase expression. Shock 21, 281-287.

Kerr, J.R. (1999). Cell adhesion molecules in the pathogenesis of and host defence against microbial infection. Mol Pathol 52, 220-230.

Kishimoto, T.K., and Rothlein, R. (1994). Integrins, ICAMs, and selectins: role and regulation of adhesion molecules in neutrophil recruitment to inflammatory sites. Adv Pharmacol 25, 117-169.

Kleinert, H., Pautz, A., Linker, K., and Schwarz, P.M. (2004). Regulation of the expression of inducible nitric oxide synthase. Eur J Pharmacol 500, 255-266.

Kmety, E., and Dikken, H., eds. (1993). Classification of the species Leptospira interrogans and history of its serovars (Groningen, The Netherlands, University Press Groningen).

Knowles, R.G., and Moncada, S. (1994). Nitric oxide synthases in mammals. Biochem J 298 (Pt 2), 249-258.

Ko, A.I., Galvao Reis, M., Ribeiro Dourado, C.M., Johnson, W.D., Jr., and Riley, L.W. (1999). Urban epidemic of severe leptospirosis in Brazil. Salvador Leptospirosis Study Group. Lancet 354, 820-825.

Ko, A.I., Goarant, C., and Picardeau, M. (2009). Leptospira: the dawn of the molecular genetics era for an emerging zoonotic pathogen. Nat Rev Microbiol 7, 736-747.

Kobayashi, Y. (2001). Clinical observation and treatment of leptospirosis. J Infect Chemother 7, 59-68.

Koizumi, N., and Watanabe, H. (2005). Leptospirosis vaccines: past, present, and future. J Postgrad Med 51, 210-214.

Krick, W.K. (1984). Prophylaxis against leptospirosis with doxycycline. N Engl J Med 311, 54.

Kunz, D., Muhl, H., Walker, G., and Pfeilschifter, J. (1994). Two distinct signaling pathways trigger the expression of inducible nitric oxide synthase in rat renal mesangial cells. Proc Natl Acad Sci U S A 91, 5387-5391.

Lai, K.N., Aarons, I., Woodroffe, A.J., and Clarkson, A.R. (1982). Renal lesions in leptospirosis. Aust N Z J Med 12, 276-279.

Landouzy, L.T.J. (1883). Fièvre bilieuse ou he'patique. Gaz Hôpital 56, 809. 
Lecour, H., Miranda, M., Magro, C., Rocha, A., and Goncalves, V. (1989). Human leptospirosis--a review of 50 cases. Infection 17, 8-12.

Lechner, M., Lirk, P., and Rieder, J. (2005). Inducible nitric oxide synthase (iNOS) in tumor biology: the two sides of the same coin. Semin Cancer Biol 15, 277-289.

Lee, K.H., Choi, H.J., Lee, M.G., and Lee, J.B. (2000). Virulent Treponema pallidum 47 kDa antigen regulates the expression of cell adhesion molecules and binding of T-lymphocytes to cultured human dermal microvascular endothelial cells. Yonsei Med J 41, 623-633.

Lee, R.E., Terry, S.I., Walker, T.M., and Urquhart, A.E. (1981). The chest radiograph in leptospirosis in Jamaica. Br J Radiol 54, 939-943.

Lee, S.H., Kim, K.K., and Choi, B.K. (2005). Upregulation of intercellular adhesion molecule 1 and proinflammatory cytokines by the major surface proteins of Treponema maltophilum and Treponema lecithinolyticum, the phylogenetic group IV oral spirochetes associated with periodontitis and endodontic infections. Infect Immun 73, 268-276.

Letunic, I., Copley, R.R., Pils, B., Pinkert, S., Schultz, J., and Bork, P. (2006). SMART 5: domains in the context of genomes and networks. Nucleic Acids Res 34, D257-260.

Levett, P.N. (2001). Leptospirosis. Clin Microbiol Rev 14, 296-326.

Levett, P.N. (2003). Usefulness of serologic analysis as a predictor of the infecting serovar in patients with severe leptospirosis. Clin Infect Dis 36, 447-452.

Liang, M., and Knox, F.G. (2000). Production and functional roles of nitric oxide in the proximal tubule. Am J Physiol Regul Integr Comp Physiol 278, R1117-1124.

Lin, C.L., Wu, M.S., Yang, C.W., and Huang, C.C. (1999). Leptospirosis associated with hypokalaemia and thick ascending limb dysfunction. Nephrol Dial Transplant 14, 193-195.

Maciel, E.A., Athanazio, D.A., Reis, E.A., Cunha, F.Q., Queiroz, A., Almeida, D., McBride, A.J., Ko, A.I., and Reis, M.G. (2006). High serum nitric oxide levels in patients with severe leptospirosis. Acta Trop 100, 256-260.

Mackay, I.M. (2004). Real-time PCR in the microbiology laboratory. Clin Microbiol Infect 10, 190-212.

Magaldi, A.J., Yasuda, P.N., Kudo, L.H., Seguro, A.C., and Rocha, A.S. (1992). Renal involvement in leptospirosis: a pathophysiologic study. Nephron 62, 332-339.

Malik, A.B., and Lo, S.K. (1996). Vascular endothelial adhesion molecules and tissue inflammation. Pharmacol Rev 48, 213-229.

Marangoni, A., Accardo, S., Aldini, R., Guardigli, M., Cavrini, F., Sambri, V., Montagnani, M., Roda, A., and Cevenini, R. (2006). Production of reactive oxygen species and expression of inducible nitric oxide synthase in rat isolated Kupffer cells stimulated by Leptospira interrogans and Borrelia burgdorferi. World J Gastroenterol 12, 3077-3081.

Markewitz, B.A., Michael, J.R., and Kohan, D.E. (1993). Cytokine-induced expression of a nitric oxide synthase in rat renal tubule cells. J Clin Invest 91, 2138-2143.

McBride, A.J., Athanazio, D.A., Reis, M.G., and Ko, A.I. (2005). Leptospirosis. Curr Opin Infect Dis 18, 376-386.

Merien, F., Truccolo, J., Baranton, G., and Perolat, P. (2000). Identification of a 36-kDa fibronectin-binding protein expressed by a virulent variant of Leptospira interrogans serovar icterohaemorrhagiae. FEMS Microbiol Lett 185, 17-22.

Merien, F., Truccolo, J., Rougier, Y., Baranton, G., and Perolat, P. (1998). In vivo apoptosis of hepatocytes in guinea pigs infected with Leptospira interrogans serovar icterohaemorrhagiae. FEMS Microbiol Lett 169, 95-102.

Miller, N.G., and Wilson, R.B. (1966). Electron microscopy of the liver of the hamster during acute and chronic leptospirosis. Am J Vet Res 27, 1071-1081.

Murdoch, D. (1980). Leptospiral uveitis. Trans Ophthalmol Soc N Z 32, 73-75. 
Nahori, M.A., Fournie-Amazouz, E., Que-Gewirth, N.S., Balloy, V., Chignard, M., Raetz, C.R., Saint Girons, I., and Werts, C. (2005). Differential TLR recognition of leptospiral lipid A and lipopolysaccharide in murine and human cells. J Immunol 175, 6022-6031.

Nakai, K., and Horton, P. (1999). PSORT: a program for detecting sorting signals in proteins and predicting their subcellular localization. Trends Biochem Sci 24, 34-36.

Nakai, K., and Kanehisa, M. (1991a). Expert system for predicting protein localization sites in gram-negative bacteria. Proteins 11, 95-110.

Nakai, K., and Kanehisa, M. (1991b). Expert system for predicting protein localization sites in gram-negative bacteria. Proteins 11, 95-110.

Nally, J.E., Chow, E., Fishbein, M.C., Blanco, D.R., and Lovett, M.A. (2005). Changes in lipopolysaccharide $O$ antigen distinguish acute versus chronic Leptospira interrogans infections. Infect Immun 73, 3251-3260.

Nascimento, A.L., Ko, A.I., Martins, E.A., Monteiro-Vitorello, C.B., Ho, P.L., Haake, D.A., Verjovski-Almeida, S., Hartskeerl, R.A., Marques, M.V., Oliveira, M.C., et al. (2004a). Comparative genomics of two Leptospira interrogans serovars reveals novel insights into physiology and pathogenesis. J Bacteriol 186, 2164-2172.

Nascimento, A.L., Verjovski-Almeida, S., Van Sluys, M.A., Monteiro-Vitorello, C.B., Camargo, L.E., Digiampietri, L.A., Harstkeerl, R.A., Ho, P.L., Marques, M.V., Oliveira, M.C., et al. (2004b). Genome features of Leptospira interrogans serovar Copenhageni. Braz J Med Biol Res 37, 459-477.

Nathan, C. (1992). Nitric oxide as a secretory product of mammalian cells. FASEB J 6, 3051-3064.

Nolte, F.S. (2004). Novel internal controls for real-time PCR assays. Clin Chem 50, 801802.

Oliveira, M.A., Caballero, O.L., Vago, A.R., Harskeerl, R.A., Romanha, A.J., Pena, S.D., Simpson, A.J., and Koury, M.C. (2003). Low-stringency single specific primer PCR for identification of Leptospira. J Med Microbiol 52, 127-135.

Ooi, B.S., Chen, B.T., Tan, K.K., and Khoo, O.T. (1972). Human renal leptospirosis. Am J Trop Med Hyg 21, 336-341.

Ooteman, M.C., Vago, A.R., and Koury, M.C. (2006). Evaluation of MAT, IgM ELISA and PCR methods for the diagnosis of human leptospirosis. J Microbiol Methods 65, 247-257.

Pacienza, N., Pozner, R.G., Bianco, G.A., D'Atri, L.P., Croci, D.O., Negrotto, S., Malaver, E., Gomez, R.M., Rabinovich, G.A., and Schattner, M. (2008). The immunoregulatory glycanbinding protein galectin-1 triggers human platelet activation. FASEB J 22, 1113-1123.

Paetzel, M., Karla, A., Strynadka, N.C., and Dalbey, R.E. (2002). Signal peptidases. Chem Rev 102, 4549-4580.

Palaniappan, R.U., Ramanujam, S., and Chang, Y.F. (2007). Leptospirosis: pathogenesis, immunity, and diagnosis. Curr Opin Infect Dis 20, 284-292.

Penna, D., De Brito, T., Pupo, A.A., Machado, M.M., Ayroza, P.A., and De Almeida, S.S. (1963). Kidney Biopsy in Human Leptospirosis. Am J Trop Med Hyg 12, 896-901.

Pereira, M.M., Andrade, J., Marchevsky, R.S., and Ribeiro dos Santos, R. (1998). Morphological characterization of lung and kidney lesions in $\mathrm{C} 3 \mathrm{H} / \mathrm{HeJ}$ mice infected with Leptospira interrogans serovar icterohaemorrhagiae: defect of CD4+ and CD8+ T-cells are prognosticators of the disease progression. Exp Toxicol Pathol 50, 191-198.

Pereira, M.M., Da Silva, J.J., Pinto, M.A., Da Silva, M.F., Machado, M.P., Lenzi, H.L., and Marchevsky, R.S. (2005). Experimental leptospirosis in marmoset monkeys (Callithrix jacchus): a new model for studies of severe pulmonary leptospirosis. Am J Trop Med Hyg 72, 13-20. 
Perriere, G., and Thioulouse, J. (1996). On-line tools for sequence retrieval and multivariate statistics in molecular biology. Comput Appl Biosci 12, 63-69.

Picardeau, M., Brenot, A., and Saint Girons, I. (2001). First evidence for gene replacement in Leptospira spp. Inactivation of L. biflexa flaB results in non-motile mutants deficient in endoflagella. Mol Microbiol 40, 189-199.

Picardeau, M., Bulach, D.M., Bouchier, C., Zuerner, R.L., Zidane, N., Wilson, P.J., Creno, S., Kuczek, E.S., Bommezzadri, S., Davis, J.C., et al. (2008). Genome sequence of the saprophyte Leptospira biflexa provides insights into the evolution of Leptospira and the pathogenesis of leptospirosis. PLoS One 3, e1607.

Pizza, M., Scarlato, V., Masignani, V., Giuliani, M.M., Arico, B., Comanducci, M., Jennings, G.T., Baldi, L., Bartolini, E., Capecchi, B., et al. (2000). Identification of vaccine candidates against serogroup $B$ meningococcus by whole-genome sequencing. Science 287, 18161820.

Plank, R., and Dean, D. (2000). Overview of the epidemiology, microbiology, and pathogenesis of Leptospira spp. in humans. Microbes Infect 2, 1265-1276.

Poland, G.A., and Jacobson, R.M. (2001). The prevention of Lyme disease with vaccine. Vaccine 19, 2303-2308.

Pozner, R.G., Negrotto, S., D'Atri, L.P., Kotler, M.L., Lazzari, M.A., Gomez, R.M., and Schattner, M. (2005). Prostacyclin prevents nitric oxide-induced megakaryocyte apoptosis. Br J Pharmacol 145, 283-292.

Puliti, M., von Hunolstein, C., Bistoni, F., Orefici, G., and Tissi, L. (2004). Inhibition of nitric oxide synthase exacerbates group B streptococcus sepsis and arthritis in mice. Infect Immun 72, 4891-4894.

Que-Gewirth, N.L., Ribeiro, A.A., Kalb, S.R., Cotter, R.J., Bulach, D.M., Adler, B., Girons, I.S., Werts, C., and Raetz, C.R. (2004). A methylated phosphate group and four amidelinked acyl chains in leptospira interrogans lipid A. The membrane anchor of an unusual lipopolysaccharide that activates TLR2. J Biol Chem 279, 25420-25429.

Ren, S.X., Fu, G., Jiang, X.G., Zeng, R., Miao, Y.G., Xu, H., Zhang, Y.X., Xiong, H., Lu, G., Lu, L.F., et al. (2003). Unique physiological and pathogenic features of Leptospira interrogans revealed by whole-genome sequencing. Nature 422, 888-893.

Riley, B.S., Oppenheimer-Marks, N., Hansen, E.J., Radolf, J.D., and Norgard, M.V. (1992). Virulent Treponema pallidum activates human vascular endothelial cells. J Infect Dis 165, 484-493.

Ristow, P., Bourhy, P., Kerneis, S., Schmitt, C., Prevost, M.C., Lilenbaum, W., and Picardeau, M. (2008). Biofilm formation by saprophytic and pathogenic leptospires. Microbiology 154, 1309-1317.

Rossetti, C.A., Liem, M., Samartino, L.E., and Hartskeerl, R.A. (2005). Buenos Aires, a new Leptospira serovar of serogroup Djasiman, isolated from an aborted dog fetus in Argentina. Vet Microbiol 107, 241-248.

Rossetti, C.A., Uhart, M., Romero, G.N., and Prado, W. (2003). Detection of leptospiral antibodies in caimans from the Argentinian Chaco. Vet Rec 153, 632-633.

Sakiniene, E., Bremell, T., and Tarkowski, A. (1997). Inhibition of nitric oxide synthase (NOS) aggravates Staphylococcus aureus septicaemia and septic arthritis. Clin Exp Immunol 110, 370-377.

Sambrook, J., MacCallum, P., and Russell, D. (2001). Molecular cloning: a laboratory manual, Third edn (Cold Spring Harbor). 
Schultz, J., Milpetz, F., Bork, P., and Ponting, C.P. (1998). SMART, a simple modular architecture research tool: identification of signaling domains. Proc Natl Acad Sci U S A 95, 5857-5864.

Schwartz, D., Mendonca, M., Schwartz, I., Xia, Y., Satriano, J., Wilson, C.B., and Blantz, R.C. (1997). Inhibition of constitutive nitric oxide synthase (NOS) by nitric oxide generated by inducible NOS after lipopolysaccharide administration provokes renal dysfunction in rats. J Clin Invest 100, 439-448.

Seijo, A., Coto, H., San Juan, J., Videla, J., Deodato, B., Cernigoi, B., Messina, O.G., Collia, O., de Bassadoni, D., Schtirbu, R., et al. (2002). Lethal leptospiral pulmonary hemorrhage: an emerging disease in Buenos Aires, Argentina. Emerg Infect Dis 8, 1004-1005.

Sellati, T.J., Abrescia, L.D., Radolf, J.D., and Furie, M.B. (1996). Outer surface lipoproteins of Borrelia burgdorferi activate vascular endothelium in vitro. Infect Immun 64, 31803187.

Sellati, T.J., Burns, M.J., Ficazzola, M.A., and Furie, M.B. (1995). Borrelia burgdorferi upregulates expression of adhesion molecules on endothelial cells and promotes transendothelial migration of neutrophils in vitro. Infect Immun 63, 4439-4447.

Setubal, J.C., Reis, M., Matsunaga, J., and Haake, D.A. (2006). Lipoprotein computational prediction in spirochaetal genomes. Microbiology 152, 113-121.

Shamaei-Tousi, A., Burns, M.J., Benach, J.L., Furie, M.B., Gergel, E.I., and Bergstrom, S. (2000). The relapsing fever spirochaete, Borrelia crocidurae, activates human endothelial cells and promotes the transendothelial migration of neutrophils. Cell Microbiol 2, 591599.

Shivakumar, S., and Shareek, P.S. (2004). Diagnosis of leptospirosis utilizing modified Faine's criteria. J Assoc Physicians India 52, 678-679.

Shpilberg, O., Shaked, Y., Maier, M.K., Samra, D., and Samra, Y. (1990). Long-term followup after leptospirosis. South Med J 83, 405-407.

Silva, E.F., Santos, C.S., Athanazio, D.A., Seyffert, N., Seixas, F.K., Cerqueira, G.M., Fagundes, M.Q., Brod, C.S., Reis, M.G., Dellagostin, O.A., et al. (2008). Characterization of virulence of Leptospira isolates in a hamster model. Vaccine 26, 3892-3896.

Solbrig, M.V., Sher, J.H., and Kula, R.W. (1987). Rhabdomyolysis in leptospirosis (Weil's disease). J Infect Dis 156, 692-693.

Stanchi, N.O. (2006). Leptospiras y Borrelias. In Microbiología biomédica, J.A. Basualdo, C.E. Coto, and R.A. de Torres, eds. (Buenos Aires, Atlante), pp. 502-508.

Stevenson, B., Choy, H.A., Pinne, M., Rotondi, M.L., Miller, M.C., Demoll, E., Kraiczy, P., Cooley, A.E., Creamer, T.P., Suchard, M.A., et al. (2007). Leptospira interrogans endostatin-like outer membrane proteins bind host fibronectin, laminin and regulators of complement. PLoS One 2, e1188.

Tamura, K., Peterson, D., Peterson, N., Stecher, G., Nei, M., and Kumar, S. (2011). MEGA5: Molecular Evolutionary Genetics Analysis Using Maximum Likelihood, Evolutionary Distance, and Maximum Parsimony Methods. Mol Biol Evol 28, 2731-2739.

Thomas, W., and Sellwood, R. (1993). Molecular cloning, expression, and DNA sequence analysis of the gene that encodes the 16-kilodalton outer membrane lipoprotein of Serpulina hyodysenteriae. Infect Immun 61, 1136-1140.

Thompson, J.D., Gibson, T.J., Plewniak, F., Jeanmougin, F., and Higgins, D.G. (1997). The CLUSTAL_X windows interface: flexible strategies for multiple sequence alignment aided by quality analysis tools. Nucleic Acids Res $25,4876-4882$. 
Torre, D., Giola, M., Martegani, R., Zeroli, C., Fiori, G.P., Ferrario, G., and Bonetta, G. (1994). Aseptic meningitis caused by Leptospira australis. Eur J Clin Microbiol Infect Dis 13, 496-497.

Torten, M., Shenberg, E., Gerichter, C.B., Neuman, P., and Klingberg, M.A. (1973). A new leptospiral vaccine for use in man. II. Clinical and serologic evaluation of a field trial with volunteers. J Infect Dis 128, 647-651.

Trevani, A.S., Andonegui, G., Giordano, M., Lopez, D.H., Gamberale, R., Minucci, F., and Geffner, J.R. (1999). Extracellular acidification induces human neutrophil activation. J Immunol 162, 4849-4857.

Trueba, G., Zapata, S., Madrid, K., Cullen, P., and Haake, D. (2004). Cell aggregation: a mechanism of pathogenic Leptospira to survive in fresh water. Int Microbiol 7, 35-40.

Tung, W.L., and Chow, K.C. (1995). A modified medium for efficient electrotransformation of E. coli. Trends Genet 11, 128-129.

Turhan, V., Atasoyu, E.M., Kucukardali, Y., Polat, E., Cesur, T., and Cavuslu, S. (2006). Leptospirosis presenting as severe rhabdomyolysis and pulmonary haemorrhage. J Infect 52, e1-2.

Verma, A., Hellwage, J., Artiushin, S., Zipfel, P.F., Kraiczy, P., Timoney, J.F., and Stevenson, B. (2006). LfhA, a novel factor $\mathrm{H}$-binding protein of Leptospira interrogans. Infect Immun 74, 2659-2666.

Victoria, B., Ahmed, A., Zuerner, R.L., Ahmed, N., Bulach, D.M., Quinteiro, J., and Hartskeerl, R.A. (2008). Conservation of the S10-spc-alpha locus within otherwise highly plastic genomes provides phylogenetic insight into the genus Leptospira. PLoS One 3, e2752.

Vieira, M.L., Atzingen, M.V., Oliveira, T.R., Oliveira, R., Andrade, D.M., Vasconcellos, S.A., and Nascimento, A.L. (2010). In vitro identification of novel plasminogen-binding receptors of the pathogen Leptospira interrogans. PLoS One 5, e11259.

Vieira, M.L., D'Atri, L.P., Schattner, M., Habarta, A.M., Barbosa, A.S., de Morais, Z.M., Vasconcellos, S.A., Abreu, P.A., Gomez, R.M., and Nascimento, A.L. (2007). A novel leptospiral protein increases ICAM-1 and E-selectin expression in human umbilical vein endothelial cells. FEMS Microbiol Lett 276, 172-180.

Vijayacharit, P., Hartskeerl, R.A., Sharma, S., Natarajaseenivasan, K., Roy, S., Terpstra, W.J., and Sehgal, S.C. (2004). A unique strain of Leptospira isolated from a patient with pulmonary haemorrhages in the Andaman Islands: a proposal of serovar portblairi of serogroup Sehgali. Epidemiol Infect 132, 663-673.

Viriyakosol, S., Matthias, M.A., Swancutt, M.A., Kirkland, T.N., and Vinetz, J.M. (2006). Toll-like receptor 4 protects against lethal Leptospira interrogans serovar icterohaemorrhagiae infection and contributes to in vivo control of leptospiral burden. Infect Immun 74, 887-895.

Vitikainen, M., Lappalainen, I., Seppala, R., Antelmann, H., Boer, H., Taira, S., Savilahti, H., Hecker, M., Vihinen, M., Sarvas, M., et al. (2004). Structure-function analysis of PrsA reveals roles for the parvulin-like and flanking $\mathrm{N}$ - and $\mathrm{C}$-terminal domains in protein folding and secretion in Bacillus subtilis. J Biol Chem 279, 19302-19314.

von Heijne, G. (1985). Signal sequences. The limits of variation. J Mol Biol 184, 99-105.

von Heijne, G. (1986). A new method for predicting signal sequence cleavage sites. Nucleic Acids Res 14, 4683-4690.

Wagenaar, J.F., de Vries, P.J., and Hartskeerl, R.A. (2004). Leptospirosis with pulmonary hemorrhage, caused by a new strain of serovar Lai: Langkawi. J Travel Med 11, 379-381. 
Wang, J., Sung, W.K., Krishnan, A., and Li, K.B. (2005). Protein subcellular localization prediction for Gram-negative bacteria using amino acid subalphabets and a combination of multiple support vector machines. BMC Bioinformatics 6, 174.

Wang, J.F., Gao, Y.Q., Lippton, H., Hyman, A., and Spitzer, J.J. (1994). The roles of nitric oxide and hydrogen peroxide production in lipopolysaccharide-induced intestinal damage. Shock 2, 185-191.

Wang, T. (2002). Role of iNOS and eNOS in modulating proximal tubule transport and acid-base balance. Am J Physiol Renal Physiol 283, F658-662.

Weigel, L.M., Radolf, J.D., and Norgard, M.V. (1994). The 47-kDa major lipoprotein immunogen of Treponema pallidum is a penicillin-binding protein with carboxypeptidase activity. Proc Natl Acad Sci U S A 91, 11611-11615.

Weil, A. (1886). Ueber eine eigentu"mliche, mit Milztumor, Icterus und Nephritis

einhergehende akute Infektionskrankheit. Dtsche Arch Klin Med 39, 209-232.

Weininger, U., Jakob, R.P., Kovermann, M., Balbach, J., and Schmid, F.X. (2010). The prolyl isomerase domain of PpiD from Escherichia coli shows a parvulin fold but is devoid of catalytic activity. Protein Sci 19, 6-18.

Weinrauch, Y., and Zychlinsky, A. (1999). The induction of apoptosis by bacterial pathogens. Annu Rev Microbiol 53, 155-187.

Werts, C., Tapping, R.I., Mathison, J.C., Chuang, T.H., Kravchenko, V., Saint Girons, I., Haake, D.A., Godowski, P.J., Hayashi, F., Ozinsky, A., et al. (2001). Leptospiral lipopolysaccharide activates cells through a TLR2-dependent mechanism. Nat Immunol 2, 346-352.

Wittwer, C.T., Herrmann, M.G., Gundry, C.N., and Elenitoba-Johnson, K.S. (2001). Realtime multiplex PCR assays. Methods 25, 430-442.

Xue, F., Yan, J., and Picardeau, M. (2009). Evolution and pathogenesis of Leptospira spp.: lessons learned from the genomes. Microbes Infect 11, 328-333.

Yang, C.W. (2007). Leptospirosis renal disease: understanding the initiation by Toll-like receptors. Kidney Int 72, 918-925.

Yang, C.W., Hung, C.C., Wu, M.S., Tian, Y.C., Chang, C.T., Pan, M.J., and Vandewalle, A. (2006). Toll-like receptor 2 mediates early inflammation by leptospiral outer membrane proteins in proximal tubule cells. Kidney Int 69, 815-822.

Yang, C.W., Wu, M.S., and Pan, M.J. (2001). Leptospirosis renal disease. Nephrol Dial Transplant 16 Supp/ 5, 73-77.

Yang, C.W., Wu, M.S., Pan, M.J., Hsieh, W.J., Vandewalle, A., and Huang, C.C. (2002). The Leptospira outer membrane protein LipL32 induces tubulointerstitial nephritis-mediated gene expression in mouse proximal tubule cells. J Am Soc Nephrol 13, 2037-2045.

Yoder, A., Wang, X., Ma, Y., Philipp, M.T., Heilbrun, M., Weis, J.H., Kirschning, C.J., Wooten, R.M., and Weis, J.J. (2003). Tripalmitoyl-S-glyceryl-cysteine-dependent OspA vaccination of toll-like receptor 2-deficient mice results in effective protection from Borrelia burgdorferi challenge. Infect Immun 71, 3894-3900.

Zaki, M.H., Akuta, T., and Akaike, T. (2005). Nitric oxide-induced nitrative stress involved in microbial pathogenesis. J Pharmacol Sci 98, 117-129.

Zuerner, R.L., Herrmann, J.L., and Saint Girons, I. (1993). Comparison of genetic maps for two Leptospira interrogans serovars provides evidence for two chromosomes and intraspecies heterogeneity. J Bacteriol 175, 5445-5451. 
